\title{
Potlining Additives
}

\section{Cooperative Agreement DE-FC36-98ID13664}

\section{Final Report}

1 August 1998 - 30 June 2004

\section{EMEC Consultants}

4221 Roundtop Road

Export, PA 15632

Contact: Dr. Rudolf Keller

Sole Proprietor

Phone: (724) 3253260

Fax: (724) 325-3260 (Call First)

e-mail: rudolfkeller@alltel.net

Prepared for:

United States Department of Energy

Office of Industrial Technologies. 


\section{FOREWORD}

This Final Report is being submitted by EMEC Consultants to the Department of Energy according to the reporting requirements of Cooperative Agreement No. DE-FC36-98ID13664. It describes and discusses the project activities during the period 1 August 1998 to 30 June 2004.

The following members of EMEC Consultants' staff contributed to the activities described in this report: B. J. Barca, J. M. Galo, D. G. Gatty, and Dr. R. Keller (Principal Investigator). W. E. Haupin, Dr. D. L. Belitskus, C. N. Cochran and G. Kefeli participated as consultants, and A. C. Hine as a laboratory assistant on temporary assignment. The experimental laboratory work was performed in EMEC Consultants' laboratory and in the Warren Haupin Pilot Facility in New Kensington, Pennsylvania.

The following were industrial companies and their primary coordinators that participated in the project:

Century Aluminum of West Virginia -- R. O. Love

Century Aluminum of Kentucky (initially NSA) -- J. V. Copenhaver \& J. Brown

Northwest Aluminum Company -- A. Barkley

SGL Carbon Corporation - D. N. Huff

Part of the experimental effort was conducted in the facilities of the industrial participants under the guidance of above coordinators: at the Century plant in Ravenswood, West Virginia (by M. McClung, S. Carte, D. Mossor, C. Lightle, J. Browning, R. Zerkle, G. Kefeli, and A. Ross); in the NSA/Century smelter in Hawesville, Kentucky (by W. Fowler and M. Terrell); in the Northwest Aluminum plant in The Dalles, Orgeon (by J. M. McClain). SGL Carbon Corporation provided cathode blocks and samples, also conducted test measurements in Germany that were coordinated by Dr. F. Hiltmann.

We gratefully acknowledge the support of the DOE Idaho Operations Office and the DOE Golden Field Office, with Mr. J. Yankeelov and Mr. B. Ring, respectively, serving as Project Managers. We thank DOE Office of Industrial Technologies (OIT) personnel, Dr. S. Dillich, S. Friedrich, and T. Robinson, for their interest and support.

This report was prepared as an account of work sponsored by an agency of the United States Government. Neither EMEC Consultants, its owner, nor any of its employees, industrial partners, or consultants makes any warranty, expressed or implied, or assumes any legal liability or responsibility for the accuracy, completeness, or usefulness of any information, apparatus, product, or process disclosed, or represents that its use would not infringe privately owned rights. Reference herein to any specific commercial product, process, or service by trade name, trademark, manufacturer, or otherwise, does not necessarily constitute or imply an endorsement, recommendation, or favoring by EMEC Consultants, by the United States Government, or by any agency thereof. 


\section{EXECUTIVE SUMMARY}

\section{BACKGROUND AND GOAL OF PROJECT}

The electrolytic production of aluminum, the only process used to produce primary aluminum commercially, is energy-intensive. New approaches to conserve energy in this process are welcome, as outlined in the "Aluminum Industry Technology Roadmap" published by the Aluminum Association ${ }^{1,2}$. The continued development of a wetted, drained cathode is one of the two R\&D needs given the top priority level among the topics concerning electrolytic reduction processes. It was the goal of the present project, "Potlining Additives", to develop a new approach to wetted cathodes and to examine its feasibility and merits.

The present project involves an invention to promote wetting of the cathode surface by aluminum metal through in-situ formation of titanium diboride resulting from the interaction of boron oxide impregnated into the cathode blocks as a potlining additive with titanium added to the metal pool. Projections of benefits to be derived from employing the concept with traditional cells have been based on improvements reported for titanium-diboride-containing coatings on cathode blocks: energy savings of up to five percent and, particularly for graphitized blocks used in many modern large cells, prolonged pot life. In the present approach, expensive titanium diboride is not employed.

After initial promising laboratory tests, EMEC Consultants proposed a study of the concept with the cooperation of several industrial partners (Century Aluminum with plants in West Virginia and Kentucky, Northwest Aluminum Company, and SGL Carbon Corporation). With the support of the Department of Energy, a three-phase program was conducted: (1) laboratory carbon samples were prepared and tested in the laboratory environment as well as in industrial cells; (2) a method to impregnate cathode blocks was established, equipment procured, and industrial tests including a pot partially equipped with impregnated blocks conducted; and (3) blocks for a cell fully equipped with impregnated blocks were prepared, installed and tested for a period of 11 months.

\footnotetext{
J. Eisenhauer, N. Margolis, S. McQueen, R. Scheer, Report of the Aluminum Technology Roadmap Workshop, November 19 - 20, 1996 published by The Aluminum Association, February 1997.

2 “Aluminum Industry Technology Roadmap, published by The Aluminum Association (2003).
} 


\section{FORMATION OF TITANIUM DIBORIDE AND WETTING OF CARBON BY ALUMINUM}

Laboratory-type carbon samples were impregnated with boron-oxide-containing melt and exposed to molten aluminum containing $0.025 \mathrm{wt} \%$ or more titanium. Upon withdrawal of the samples, a layer of metal adhered to the carbon surface. Figure 1 shows such a sample and a non-impregnated comparison piece. Exposure tests were performed in the laboratory and in industrial production units of two smelters.

Figure 1: Comparison of non-impregnated sample to impregnated-wetted sample after exposure to aluminum containing titanium in an industrial cell.

Impregnated

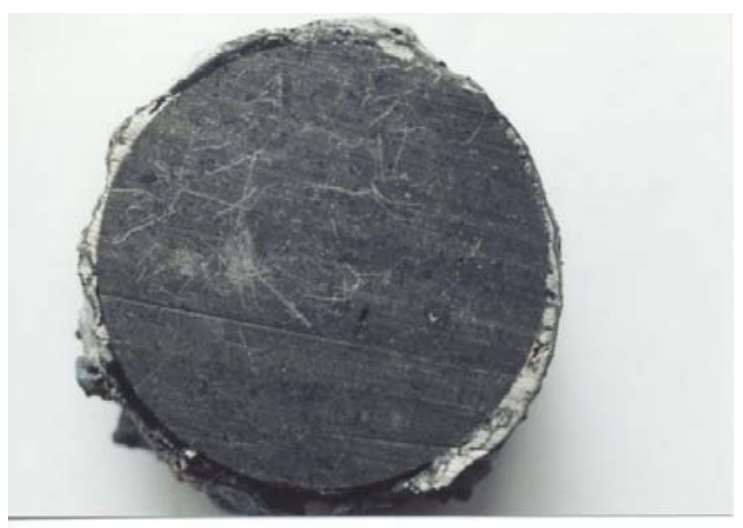

Non-impregnated

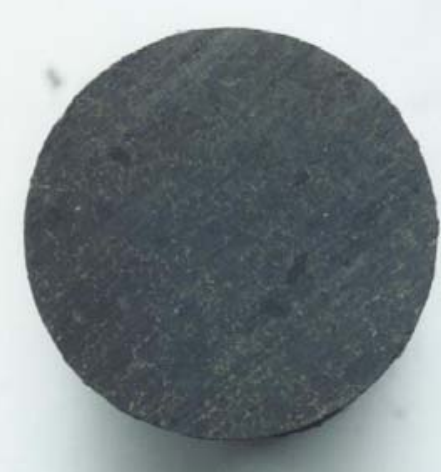

Examination by scanning electron microscopy (SEM) showed an accumulation of titanium-rich particles in the aluminum adjacent to the carbon surface. While boron could not be detected with the equipment available at RJ Lee Group in Monroeville, Pennsylvania, SEM analyses were conducted with special equipment at Aventis Research and Technologies in Germany and by Charles Evans \& Associates in Sunnyvale, California. Figure 2 shows a result indicating the presence of titanium diboride; a semi-quantitative evaluation indicated the presence of titanium and boron in the atomic ratio of $1: 2$.

It should be noted that the titanium diboride did not appear to cover the carbon as a continuous coating, as it was found in recovered samples in an adhering aluminum layer. This may be consistent with observations reported by Comalco authors who found a viscous layer or $\mathrm{TiB}_{2} / \mathrm{Al}$ slurry forming on top of their applied coating containing titanium diboride ${ }^{3}$.

3 M. P. Taylor, G. J. Hardie, F. J. Stevens McFadden, and W. Uru, "Use of Refractory Hard Cathodes to Reduce Energy Consumption in Aluminum Smelting", Presented at the Materials Conference, San Francisco (2000). 
Figure 2: Evidence of $\mathrm{TiB}_{2}$ from SEM Analysis

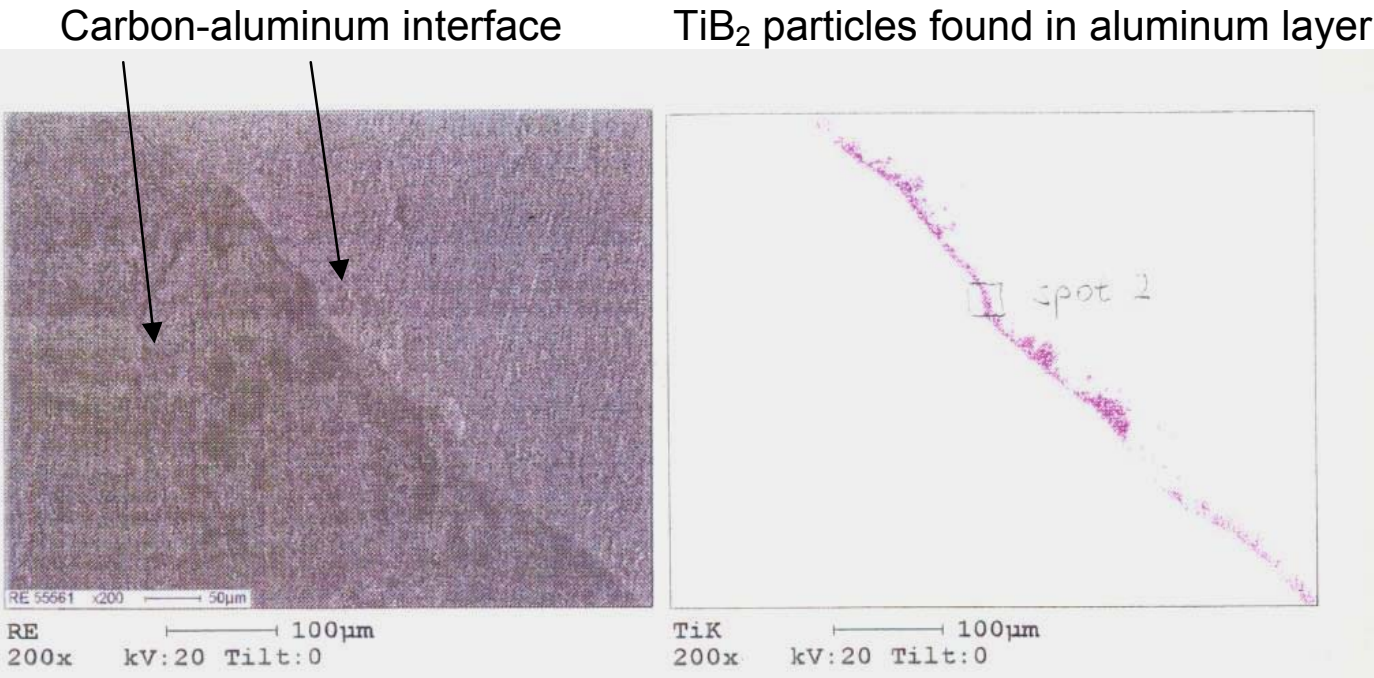

\section{IMPREGNATION OF CATHODE MATERIAL WITH BORON OXIDE}

Of several approaches tested, the impregnation of a boron oxide melt containing small amounts of water-free borax into cathode blocks under pressure of about 160 psi (1.1 $\mathrm{MPa}$ ) and at a temperature of $800{ }^{\circ} \mathrm{C}$ was selected for experimentation on the larger scale. A custom-designed pressure vessel was acquired from Autoclave Engineers. It accommodated the impregnation of half-length industrial cathode blocks, as well as, their preheating above the melt. The withdrawal of a cathode block from the vessel is shown in Figure 3.

Impregnated amorphous blocks contained about 12 to $14 \mathrm{wt} \% \mathrm{~B}_{2} \mathrm{O}_{3}$, graphitized blocks 14 to $16 \mathrm{wt} \%$. Impregnated blocks had to be so handled as to exclude excessive exposure to moisture, as boron oxide reacts with $\mathrm{H}_{2} \mathrm{O}$ to form boric acid, $\mathrm{H}_{3} \mathrm{BO}_{3}$, which releases the water only at temperatures above $300^{\circ} \mathrm{C}$. 
Figure 3: Cathode block being removed from the pressure vessel after impregnation.

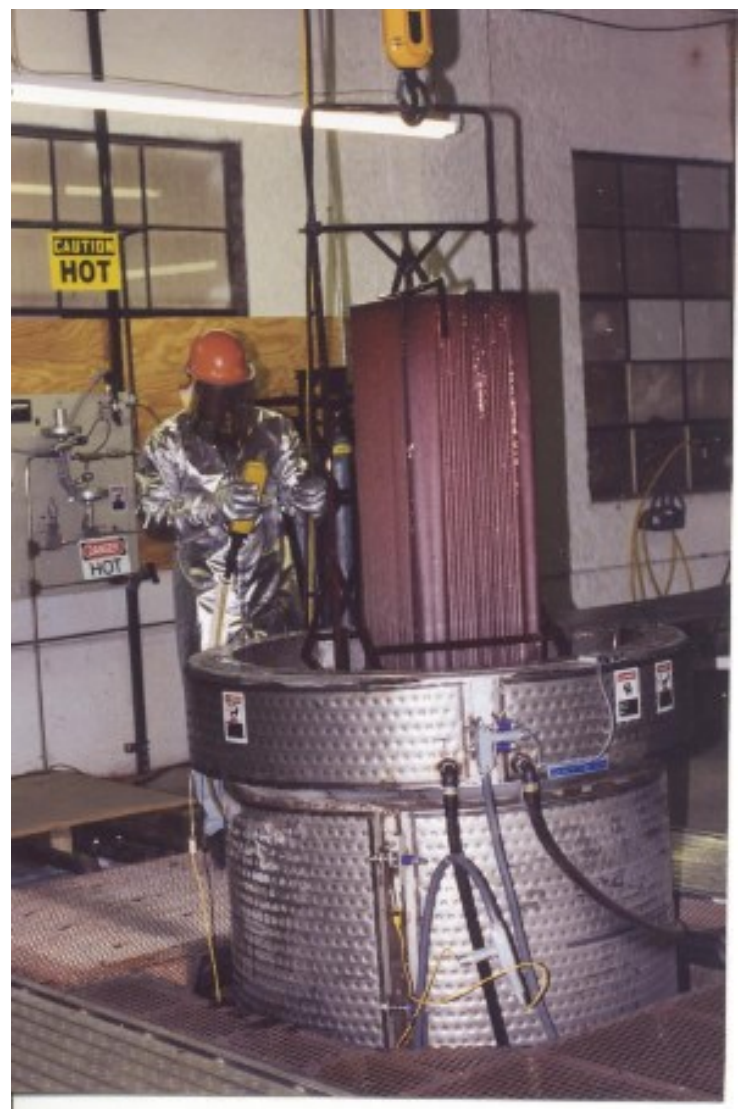

\section{PHASE (TASK) I. ESTABLISHMENT OF IMPREGNATING TECHNIQUE AND TEST OF LABORATORY-TYPE SAMPLES}

In this first phase, the most promising impregnation procedure and pertaining process parameters were established in the laboratory. A stainless steel pressure vessel allowing temperatures up to $800^{\circ} \mathrm{C}$ was built. Samples were typically 2 inches $(5 \mathrm{~cm})$ in diameter and 6 inches $(15 \mathrm{~cm})$ in length.

Samples were also prepared by mixing boron oxide with green carbon material that were subsequently baked. Resulting material properties, however, were not satisfactory.

Arrays of samples were exposed to the metal pool of industrial pots at NSA (later Century Aluminum of Kentucky) and Northwest Aluminum in The Dalles; conclusive, positive results were obtained. Tests of samples inserted into a cathode block of an industrial cell at Century of West Virginia in Ravenswood were inconclusive because 
any titanium diboride formed may have dissipated into the metal bulk in the process of cooling and solidification.

\section{PHASE (TASK) II. ACQUISITION OF CAPABILITY TO IMPREGNATE COMMERCIAL CATHODE BLOCKS AND 6-MONTHS INDUSTRIAL TESTING}

The pressure vessel was acquired from Autoclave Engineers and installed in the Warren Haupin Pilot Facility, which was set up for the work on this project. Each halflength block was impregnated in two successive workdays, with an overnight intermission. In impregnation periods, a pressure of $160 \mathrm{psi}(1.1 \mathrm{MPa})$ and a temperature of $800{ }^{\circ} \mathrm{C}$ were maintained. Twelve half-length blocks were processed for Phase II tests and 26 for the Phase III test.

Six half-length amorphous blocks were installed in a pot at the Ravenswood Century Aluminum plant. The pot was operated for six months with periodic titanium additions to the metal pool. A partial autopsy was conducted, with core-drilled samples being collected. The pot was later restarted. Analysis of the samples revealed a loss of about half of the initial boron oxide content. Wetting of the carbon surface by the metal could not be observed, as any metal appeared to become part of the bulk metal pad on solidification.

Six graphitized half-length blocks provided by the Goldendale plant of Golden Pacific Northwest were impregnated and returned. These blocks, however, could not be tested due to economic problems at Golden Pacific Northwest.

A test with seam mix to which boron oxide had been added was performed at the Hawesville smelter of NSA (now Century Aluminum of Kentucky). A partial autopsy after six months revealed that poor seam quality resulted.

\section{PHASE (TASK) III. FULL CELL INDUSTRIAL TESTING}

Twenty-six half length blocks were impregnated, and the collector bars were mounted by Precision Inc. in Sistersville, WV. These blocks were then installed and run in a pot at Ravenswood. This pot was operated for 332 days at a nominal line current of $93 \mathrm{kA}$. During the operation, the pot displayed a strong tendency to have excess noise and required a somewhat higher than normal average voltage. Its behavior indicated an excessive heat loss through the bottom, but the reason could not be identified. Boron oxide penetrated into the first refractory layer, but measurements of the heat conductance did not reveal an abnormality. About half to two thirds of the initial boron oxide content was present in the core-drilled samples. Some boron oxide migrated into the seams. The presence of titanium diboride was indicated in metal that was adhering to the surface of core-drilled samples. The wear rate of the blocks was extremely low; 
no hole developed at the tapping site, a wear factor often present in other cells. Testing for cyanide yielded insignificant contents.

\section{CONCLUSIONS AND RECOMMENDATIONS}

The principal concept of the invention was confirmed by laboratory studies and tests in industrial cells: boron oxide impregnated into cathode blocks reacts with titanium added to molten aluminum in contact with the cathode carbon to form titanium diboride which promotes wetting of the cathode block surface by the aluminum.

Cathode blocks impregnated with boron-oxide-containing melt lost a substantial but not prohibitively large portion of the boron oxide during a 6-month and 11-month operation, respectively. It is, however, not known how much was lost to the electrolyte in the startup phase of the pot, but any such losses could potentially be reduced. Migration of boron oxide into the refractory layer below the block was found in the 11-month test, but it is believed that this loss of boron oxide could be suppressed with a suitable barrier.

The operation of a production cell fully equipped with impregnated amorphous blocks did not yield a superior cell performance, as had been reported by others for cells provided with a coating containing titanium diboride. Excessive heat loss through the cell bottom apparently fostered the formation of sludge and deposits, which led to instability (noise). Excellent dimensional stability of the blocks was observed, an important observation in view of pot life problems recently being experienced for modern cells with graphitized blocks.

Additional experimentation in a cell with graphitized blocks would be highly desirable. Such a test had been planned but could not be executed due to unfortunate economic factors in the industry. The heat loss through the bottom should be examined in additional testing. It should be established if the excessive heat loss might have been caused by an abnormality associated with the particular test cell. Any higher heat transfer through the wetted block-aluminum interface should be counteracted by additional thermal insulation.

The mothballed impregnation equipment could be reactivated for tests in additional industrial cells, possibly for a series of 10 units. Minor modifications and the operation of a pre-heat furnace could permit the impregnation of some full-length blocks. For testing on a larger scale and the commercial implementation of the technology, larger impregnation vessels would decrease the impregnation time for testing and application, as well as improve factors of economy.

Substantial economic benefits for the practical implementation of the technology are projected, especially for modern cells with graphitized blocks. For example, with an energy savings of about $5 \%$ and an increase in pot life from 1500 to 2500 days, a cost savings of $\$ 0.023$ per pound of aluminum produced is projected for a $200 \mathrm{kA}$ pot. 


\section{TABLE OF CONTENTS}

$\begin{array}{ll}\text { FOREWORD } & 2\end{array}$

EXECUTIVE SUMMARY 3

$\begin{array}{ll}\text { TABLE OF CONTENTS } & 9\end{array}$

$\begin{array}{ll}\text { LIST OF FIGURES AND TABLES } & 10\end{array}$

$\begin{array}{ll}\text { PROJECT SUMMARY } & 12\end{array}$

GOALS OF THE PROJECT

Technology Status - Aluminum Roadmap $\quad 14$

$\begin{array}{ll}\text { Wettable Cathodes } & 14\end{array}$

$\begin{array}{ll}\text { Potlining Additives } & 16\end{array}$

$\begin{array}{ll}\text { Projected Benefits } & 16\end{array}$

$\begin{array}{lc}\text { EXPERIMENTAL PART } & 18\end{array}$

$\begin{array}{lr}\text { Experimental Plan } & 18\end{array}$

Phase I Lab Scale Testing $\quad 18$

Phase II Impregnation Capability and Limited Tests in Industrial Cells 37

Phase III Full Cell Test 43

CONTINUATION OF EFFORT AND COMMERCIALIZATION ASPECTS 68

$\begin{array}{ll}\text { Continuation of Effort } & 68\end{array}$

$\begin{array}{ll}\text { Re-use of Pilot Equipment } & 68\end{array}$

$\begin{array}{ll}\text { Commercial Production Equipment } & 69\end{array}$

$\begin{array}{ll}\text { Projection of Cost Benefits } & 70\end{array}$

$\begin{array}{ll}\text { Patent Situation } & 72\end{array}$

$\begin{array}{ll}\text { The Virtual Consortium } & 73\end{array}$

CONCLUSIONS AND RECOMMENDATIONS

$\begin{array}{ll}\text { APPENDIXES } & 77\end{array}$ 


\section{LIST OF FIGURES AND TABLES}

\section{Figures:}

Figure 1: Comparison of non-impregnated sample to impregnated-wetted

Figure 2: Evidence of $\mathrm{TiB}_{2}$ from SEM Analysis. $\quad 5$

Figure 3: Cathode block being removed from the pressure vessel after impregnation. 6

Figure 4: Performance estimates for Comalco coated normal cell alternatives. $\quad 17$

Figure 5: Testing of laboratory samples. 22

$\begin{array}{ll}\text { Figure 6: Testing of array of samples at NWA. } & 28\end{array}$

Figure 7: Cross-section comparison of samples exposed in industrial cell (NWA). 31

Figure 8: Samples exposed at NSA showing an adherent metal layer. 33

Figure 9: SEM/EDS examination of sample exposed in NSA industrial cell. 35

$\begin{array}{ll}\text { Figure 10: Design of the pressure vessel. } & 38\end{array}$

Figure 11: Vessel arrival, installation, and block impregnation. 39

Figure 12: Layout of samples taken during partial autopsy. 42

Figure 13: Impregnated blocks in the pot prior to ramming paste being added. 43

$\begin{array}{ll}\text { Figure 14: Operating voltage and noise observations. } & 47\end{array}$

Figure 15: Bars and connections.

Figure 16: The pot before and after the metal pad was removed. 51

Figure 17: Location of the core samples. 53

Figure 18: Typical 2-inch diameter core sample (sectioned after recovery). 54

Figure 19: Appearance of the cross section after removing 4 half-length blocks. $\quad 55$

Figure 20: Boron oxide analytical results in wt\%. 58

$\begin{array}{ll}\text { Figure 21: SEM analysis results. } & 62\end{array}$

Figure 22: Analysis of non-metal material on the carbon surface. 63

Figure 23: Thermal conductivity data of powder refractory material. 65 


\section{Tables:}

Table 1: Results obtained with mixed ramming paste carbon samples containing boron oxide.

Table 2: Results obtained with impregnated samples of graphitized and amorphous matrix and with non-impregnated samples.

Table 3: Phase I industrial cell tests.

Table 4: Weight gains of individual blocks used for the test cell.

Table 5: Average cathode voltage drops for 2A39 and 2A50.

Table 6: Analysis for boron oxide and sodium (in wt\%).

Table 7: Average boron oxide content remaining in the cathode blocks.

Table 8: Electrical resistivity data from laboratory testing at 30 amps.

Table 9: Calculated thermal conductivity data. 


\section{PROJECT SUMMARY}

In this project, a concept to improve the performance of aluminum production cells by introducing potlining additives was examined and tested. Boron oxide was added to cathode blocks, and titanium was dissolved in the metal pool; this resulted in the formation of titanium diboride and caused the molten aluminum to wet the carbonaceous cathode surface. Such wetting reportedly leads to operational improvements and extended cell life. In addition, boron oxide suppresses cyanide formation.

The project was conducted in three phases:

In the first phase, ways to add boron oxide to cathode material were investigated in the laboratory. A pressurized impregnation using a boron-oxide-containing melt with pressures of $160 \mathrm{psi}(1.1 \mathrm{MPa})$ applied at $800^{\circ} \mathrm{C}$ emerged as our standard procedure. Addition of boron oxide to green paste and subsequent baking did not yield material of acceptable properties. Laboratory-type samples were exposed to molten aluminum to which some titanium had been added. This exposure was practiced in both a laboratory furnace and the metal pool of industrial cells. The formation of titanium diboride was indicated by SEM analysis and wetting was observed at titanium contents of $0.025 \mathrm{wt} \%$ and higher. Discrete particles of titanium diboride were observed in the aluminum adjacent to the carbon surface.

In the second phase, the capability of impregnating industrial cathode blocks was established; a suitable custom-made pressure vessel was procured from Autoclave Engineers. A two-day routine was adopted to reach impregnation levels of $12 \mathrm{wt} \%$ boron oxide for amorphous blocks and $14 \mathrm{wt} \%$ for graphitized blocks. Six impregnated half-length blocks were delivered to each Century Aluminum of West Virginia and the Goldendale smelter in the State of Washington. A six-month test was conducted in Ravenswood with a partial autopsy (the pot was subsequently restarted). The coredrilled samples indicated a loss of about half the impregnate; signs of wetting could not be found, as all the metal reported to the solidifying metal pad. Due to economic factors, the test in Goldendale could not be conducted.

A pot in Ravenswood was fully equipped with impregnated blocks in Phase III. It was operated as a unit of a regular potline for eleven months. Operational difficulties (high noise, requirement of somewhat higher voltage -- increase of cell current was not an option for technical reasons --, bottom sludge and deposits) were experienced, except in an initial and in an intermittent period. These difficulties were likely due to excessive heat loss through the bottom, the cause of which could not be identified conclusively. Boron oxide leaked into the refractory layer, but heat conductance measurements revealed no increase of thermal conductivity. Analysis of core-drilled samples obtained in the autopsy indicated that between a third and half of the boron oxide was lost, some boron oxide also penetrated into the seams. Titanium accumulation (a sign for the 
presence of $\mathrm{TiB}_{2}$ ) was observed by SEM in aluminum adhering to the cathode carbon. Practically no wear of the cathode blocks could be detected after this 1-year period of operation.

In essence, the validity of the concept was confirmed by the results. Some operational difficulties may be avoided by introducing a barrier to prevent the leakage of boron oxide into the refractories. It is not clear how much boron oxide is lost during cell startup, and this should be a topic for optimizing the process.

A low wear rate of the cathode blocks would be of much greater importance for cells equipped with graphitized rather than amorphous blocks, as pot life problems are being reported for some of the modern cells. Extension of the testing to pots fully equipped with impregnated graphitized cathode blocks is highly recommended; favorable economic benefits are projected in this area for commercialization. 


\section{GOALS OF THE PROJECT}

\section{TECHNOLOGY STATUS -- ALUMINUM ROADMAP}

The production of primary aluminum is an energy-intensive process. Since the invention by Hall and Héroult more than a century ago, aluminum smelting is practiced by the electrolysis of aluminum oxide dissolved in a fluoride melt. While great progress has been achieved in making the aluminum more and more affordable, additional improvements of the process are still desirable.

The U. S. aluminum industry recently has undertaken a bold technology planning initiative to position itself to compete effectively in global markets ${ }^{1,2,4,5}$. Overall, the domestic industry has relinquished clear technological leadership, and new developments often originate from foreign sources. This is particularly true in the area targeted by this project: cathode technology in the primary aluminum production, which is identified in the Aluminum Technology Roadmap as a key area.

\section{WETTABLE CATHODES}

Liquid aluminum in aluminum production cells does not wet the underlying carbonaceous cathode material. For this reason, a relatively deep metal pool is necessary, and this prohibits certain energy savings possibilities. Therefore, research on wettable cathodes has been supported by the Department of Energy over many years. Thin-metal-layer or drained cathode concepts, which would allow design of cells with reduced anode-cathode distance, were targeted.

Early work on cost-effective titanium-diboride-containing coatings for use with HallHéroult cathodes was conducted by Martin Marietta. In the beginning of these studies, the bottom of a conventional VSS cell was coated with a proprietary $\mathrm{TiB}_{2}$ cathode material. Reduction of noise and muck was reported, along with a figure for energy savings of $0.26 \mathrm{kWh}$ per pound of aluminum produced ${ }^{6}$. Emphasis was later put on

4 The Aluminum Association, "Aluminum Industry Technology Roadmap", May 1997.

$5 \mathrm{H}$. S. Kenchington, J. L. Eisenhauer, and J. A. S. Green, "Implementing the Aluminum Technology Roadmap", Presentation at 1998 Annual TMS Meeting, San Antonio, TX.

6 L. G. Boxall, A. V. Cooke, and H. W. Hayden, "Use of $\mathrm{TiB}_{2}$ Cathode Material Application and Benefits in Conventional VSS Cells", Light Metals 1984, pp. 573-588. 
drained cathode concepts; developments in cooperation of Martin Marietta with Kaiser Aluminum were supported by the Department of Energy. Later, Comalco continued this work in Australia. Comalco authors have recently reported on long-term benefits derived from coatings containing titanium diboride ${ }^{3}$.

A TINOR coating consisting of aluminum oxide and titanium diboride has been developed by Moltech ${ }^{7.8}$. TINOR coatings are applied at 1-mm thickness to the carbon bottoms. For drained surfaces, a thicker coating, THICKNOR, is used.

SGL Carbon in cooperation with Hoechst AG was investigating the application of titanium diboride by a plasma spray technique in vacuum ${ }^{9}$.

These options all involve high-cost titanium diboride material. To circumvent this, electrodeposition and growth from the metal phase have been suggested ${ }^{10}$, but this approach has not led to commercial success.

Durability of the coating is a main concern. Coatings applied at the beginning of a cell's life generally do not last. Titanium diboride has a solubility in the metal. Observed values generally agree with the solubility product given in the literature ${ }^{11}$ and amount to $56.5 \mathrm{mg} \mathrm{TiB} 2$ per $\mathrm{kg} \mathrm{Al}$ at $960{ }^{\circ} \mathrm{C}$ in aluminum containing no other titanium or boron. Assuming saturation of the aluminum produced with $\mathrm{TiB}_{2}, 56.5 \mathrm{~g} \mathrm{TiB}_{2}$ is consumed per ton of aluminum produced; a life of 1 to 2 years may be expected for a 1-mm layer of composite coating. Nevertheless, Comalco, with thicker coatings, experienced benefits outlasting the predicted period ${ }^{3}$.

7 J. A. Sekhar, V. de Nora, J. Liu, and X. Wang, "TiB $/ 2$ Colloidal Alumina Carbon Cathode Coatings in Hall-Héroult and Drained Cells", Light Metals 1998, pp. 605-615.

8 Moltech, "Moltech Products for Aluminum Cells", promotional publication, February 1998.

9 K. Seitz and F. Hiltmann, "Titanium Diboride Plasma Coating of Carbon Cathode Materials, Part I: Coating Process and Microstructure; Part II: Characterization", Light Metals 1998, pp. 379-383; 385-390.

10 D. W. Townsend, "Supersaturation Plating of Aluminum Wettable Cathode Coatings During Aluminum Smelting in Drained Cathode Cells", U. S. Patent No. 5,028,301 (1991).

11 N. J. Finch, "The Mutual Solubilities of Titanium and Boron in Pure Aluminum", Met. Trans. Vol. 3, 2709 (1972). 


\section{POTLINING ADDITIVES}

Considerations of cost and the limited time of effectiveness have been the main factors responsible for the use of titanium diboride not having been introduced in commercial practice. The presently proposed concept promises to advance the technology in both regards. Based on preliminary experimental data, EMEC Consultants suggested a concept involving the achievement of wettability of the carbon substrate by aluminum metal by addition of boron oxide to the cathode and titanium to the metal. It was postulated that such wettability results from the production of titanium diboride on the carbonaceous cathode block surface, according to the reaction:

$$
\mathrm{B}_{2} \mathrm{O}_{3}+\mathrm{Ti}+2 \mathrm{Al}--->\mathrm{TiB}_{2}+\mathrm{Al}_{2} \mathrm{O}_{3} \text {. }
$$

It was anticipated that this formation continues as titanium diboride dissolves, thus the coating repairs itself. The approach, therefore, achieves a long-lasting effect with lowcost materials and treatment.

The present project was designed to test the validity of this concept in the laboratory, as well as, in tests in industrial cells.

\section{PROJECTED BENEFITS}

Benefits leading to energy savings are projected as follows:

--- cell voltage reduction by $0.2 \mathrm{~V}(0.05 \mathrm{~V}$ at the carbon-metal interface, $0.15 \mathrm{~V}$ in the electrolyte)

--- current efficiency increase by 1 to $2 \%$

These projections are in line with estimates in the literature ${ }^{12}$. Figure 4 presents improvements estimated by Mark Taylor et al based on Comalco results ${ }^{3}$.

12 H. Zhang, V. de Nora, and J. A. Sekhar, "Materials Used in the Hall-Heroult Cell for Aluminum Production", published by TMS (1994). 
Figure 4: Performance estimates for Comalco coated normal cell alternatives.

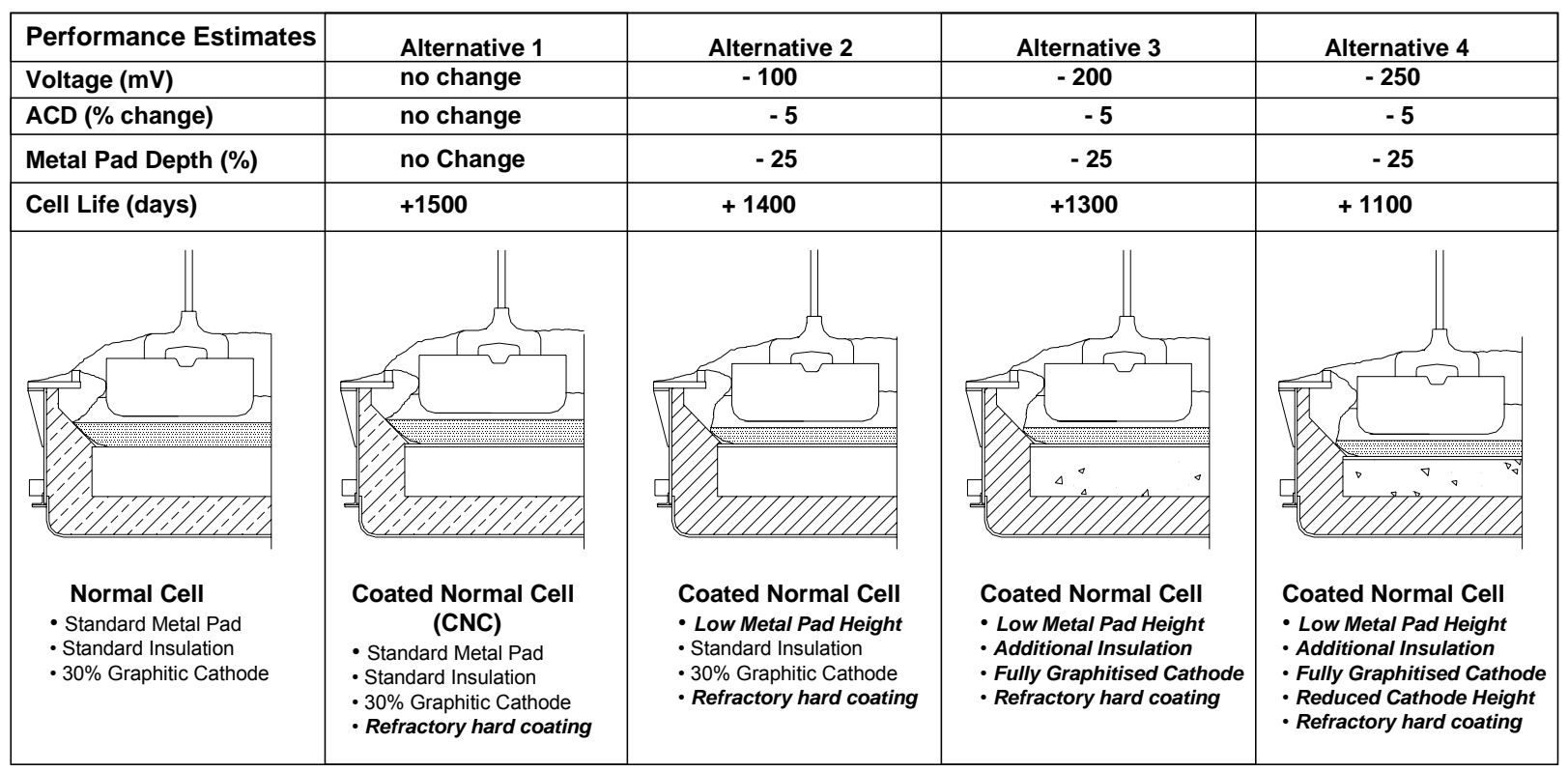

Of substantial interest is also the projected increase in potlife, as the cathode wear can be expected to be reduced on a wetted surface. This is particularly important for modern cells with graphitized cathode blocks, as this material is relatively soft and has recently led to disappointing cathode life in industry.

Potlining additives were originally studied by EMEC Consultants to suppress cyanide formation in cathode blocks. This approach was studied on SBIR projects funded by the Environmental Protection Agency. It has been published ${ }^{13}$ and has led to a patent ${ }^{14}$. Spent blocks impregnated with boron oxide according to the present project can be expected to contain negligible amounts of cyanide. This was actually confirmed in a full cell test.

13 R. Keller, D. B. Stofesky, and C. N. Cochran, "The Potential of Potliner Additives to Suppress Cyanide Formation in Hall-Heroult Cells”, Light Metals 1995, pp. 345-347.

14 R. Keller, C. N. Cochran, and D. B. Stofesky, U. S. Patent No. 5,538,604 (1996-07-23),

"Suppression of Cyanide Formation in Electrolytic Cell Lining". 


\section{EXPERIMENTAL PART}

\section{EXPERIMENTAL PLAN}

The work was planned to progress in three phases. The first phase involved the preparation of laboratory-type samples and their testing in the laboratory and in industrial cells. Equipment to impregnate cathode blocks with boron-oxide-containing melt was designed, procured and operated in Phase II. This phase also encompassed tests with a few single blocks in an industrial cell. In the third phase, a cell was fully equipped with impregnated blocks and operated for 11 months, after which period a full cell autopsy was conducted.

\section{PHASE I LAB SCALE TESTING}

\section{Preparation and Sources of Laboratory Samples}

Laboratory samples were typically core-drilled samples, 2 inch $(5 \mathrm{~cm})$ diameter and 4 to 8 inches $(10$ to $20 \mathrm{~cm})$ in length. In later stages, also rectangular samples of the dimensions 2" $(5 \mathrm{~cm}) \times 3$ " $(7.5 \mathrm{~cm}) \times 6$ " $(15 \mathrm{~cm})$ were supplied by SGL Carbon.

Sources for laboratory samples to be impregnated with boron oxide were:

Century Aluminum

SGL Carbon
Samples of core-drilled amorphous block material containing $50 \%$ graphite

Samples of core-drilled graphitized block material

Samples of core-drilled amorphous block material containing $30 \%$ graphite

Laboratory samples with boron oxide added before baking were prepared by Century Aluminum of West Virginia (Tony Ross), in coordination with SGL Carbon. In addition, ramming paste was mixed with various amounts of boron oxide (provided by $U$. S. Borax). The material was pressed into blocks and baked at approximately $1,000{ }^{\circ} \mathrm{C}$. Samples were then core-drilled from such blocks. 
Samples representing amorphous cathode block material were prepared using a block mix of the following components:

$\begin{array}{ll}\text { anthracite } & 25 \% \text { flour } \\ & 25 \% 1-5 \mathrm{~mm} \\ & 25 \% 5-10 \mathrm{~mm} \\ \text { graphite: } & 25 \% 0-4 \mathrm{~mm}\end{array}$

boron oxide: -60 mesh, as provided by U.S. Borax, added to formulation at $0,5,10$ and $20 \mathrm{wt} \%$ levels; or finer (ground), added as substitute for the flour anthracite part

For the preparation of ramming paste samples, batches of appr. 9,000-g of ramming paste were mixed for 20 minutes in a laboratory mixer with various amounts of boron oxide ( -60 mesh technical grade obtained from U. S. Borax). The ramming paste contained about $15 \%$ coal tar pitch, the rest anthracitic aggregate. The shell of the mixer was kept at $90^{\circ} \mathrm{F}$. When used in practice without additive, the ramming mix flows when heated to $100{ }^{\circ} \mathrm{F}$ before application. From the mixed mass, three blocks of approximately $3,000 \mathrm{~g}$ were pressed at about $4,000 \mathrm{psi}$. Pressed blocks then were baked in a furnace whose temperature was slowly raised to $600{ }^{\circ} \mathrm{C}$ at a rate of 12 to $14^{\circ} \mathrm{C}$ per hour. Heating to $1,000 \pm 10^{\circ} \mathrm{C}$ then progressed at a faster rate and the blocks were kept at this temperature for 6 hours. Open pinhole-type pores were noticed at the surface after baking, along with some white coating. Three samples, $5 \mathrm{~cm}$ ( 2 inches) in diameter and approximately $15 \mathrm{~cm}$ (6 inches) long, were core-drilled from these blocks, one core per block.

Essentially the same procedure was followed for the preparation of block mix samples representing amorphous block material. Anthracite coal was sized to the required specifications by screening the material through Tyler screens having the desired millimeter designations. All of the materials specified for the particular batches were pre-weighed and charged into a Baker-Perkins sigma blade mixer. The oil-heated mixer was operated for approximately 50 minutes to obtain the target temperature of $155 \pm$ $5^{\circ} \mathrm{C}$. From this material, blocks were pressed and baked, and specimens prepared as described above.

A finer grain size (- 200 mesh) boron oxide was used for some specimens. This boron oxide material was prepared by grinding the -60 mesh boron oxide obtained from U.S. Borax in a ring/puck disc mill. The finer ground $\mathrm{B}_{2} \mathrm{O}_{3}$ was added as a substitute for (part of) the flour anthracite fraction. 


\section{Impregnation of Laboratory Samples}

\section{Deposition of Boron Oxide from Impregnated Solutions}

Attempts were made to impregnate solutions of boron oxide into the pores of cathode block material. Boron oxide, $\mathrm{B}_{2} \mathrm{O}_{3}$, dissolves in water, forming boric acid, $\mathrm{H}_{3} \mathrm{BO}_{3}$. Its solubility according to the 1973 edition of the Handbook of Chemistry and Physics is $6.35 \mathrm{~g}$ in $100 \mathrm{~g}$ of water at $30^{\circ} \mathrm{C}$ and $27.6 \mathrm{~g}$ in $100 \mathrm{~g}$ of water at $100^{\circ} \mathrm{C}$. Corresponding values for $\mathrm{B}_{2} \mathrm{O}_{3}$ glass are given as $1.1 \mathrm{~g}$ at $0{ }^{\circ} \mathrm{C}$ and $15.7 \mathrm{~g}$ at $100{ }^{\circ} \mathrm{C}$. Boric acid, $\mathrm{H}_{3} \mathrm{BO}_{3}$, transforms into meta-boric acid, $\mathrm{HBO}_{2}$, at $169{ }^{\circ} \mathrm{C}$. $\mathrm{HBO}_{2}$ has a melting point of $236{ }^{\circ} \mathrm{C}$. $\mathrm{H}_{3} \mathrm{BO}_{3}$ loses $1 \frac{1}{2} \mathrm{H}_{2} \mathrm{O}$ at $300{ }^{\circ} \mathrm{C}$ to form water free $\mathrm{B}_{2} \mathrm{O}_{3}$. A high solubility of $20.2 \mathrm{~g}$ in $100 \mathrm{~g}$ of methanol at $25^{\circ} \mathrm{C}$ is indicated for $\mathrm{H}_{3} \mathrm{BO}_{3}$.

Repetitive impregnation with solutions and evaporation of the solvent yielded positive results, but the procedure would be too cumbersome for industrial implementation.

\section{$\underline{\text { Impregnation with Tar }}$}

Impregnation of porous materials with tar is an established process, practiced, e.g., by Wulfrath Refractories, Inc. in Tarentum, Pennsylvania. The impregnation of cathode block material with tar was studied to compare this impregnation involving another viscous medium with the impregnation with boron oxide. The possibility to impregnate boron oxide suspended in tar was also examined, but the boron oxide separated out and no satisfactory impregnation process was developed.

\section{$\underline{\text { Impregnation of Boron Oxide Melts }}$}

\section{Characteristics of Boron Oxide, $\mathrm{B}_{2} \mathrm{O}_{3}$, Melts}

A melting point of $460{ }^{\circ} \mathrm{C}$ is given for water-free crystalline boron oxide, $\mathrm{B}_{2} \mathrm{O}_{3}$, in the 1973 edition of the Handbook of Chemistry and Physics. Boron oxide, however, normally solidifies in a vitreous form, as it forms supercooled liquids that show little tendency to crystallize. The glass-like melts of boron oxide, $\mathrm{B}_{2} \mathrm{O}_{3}$, exhibit high viscosities. Values from literature published in 1935 (not much different from more recent data) are:
At $450^{\circ} \mathrm{C}$
$1.7 \times 10^{5}$ poise
at $500{ }^{\circ} \mathrm{C}$
$3.9 \times 10^{4}$ poise
at $600{ }^{\circ} \mathrm{C}$
$4.8 \times 10^{3}$ poise
at $700{ }^{\circ} \mathrm{C}$
$8.5 \times 10^{2}$ poise

at $800^{\circ} \mathrm{C} \quad 2.6 \times 10^{2}$ poise

at $900{ }^{\circ} \mathrm{C} \quad 1.2 \times 10^{2}$ poise 
Molten boron oxide is one of the few oxides the surface tension of which increases with temperature (others being $\mathrm{GeO}_{2}$ and $\mathrm{SiO}_{2}$, but not $\mathrm{Al}_{2} \mathrm{O}_{3}$ ). A straight-line equation, $\mathrm{y}=$ $47.6+0.0354 \mathrm{t}\left(\mathrm{y}\right.$ in dynes/cm and $\mathrm{t}$ in ${ }^{\circ} \mathrm{C}$ ) was found in 1947 and later confirmed.

Impregnation of Boron Oxide Melts by Applying Vacuum and Pressure

A pressure vessel, with a water-cooled top, was constructed to be used in our available crucible furnace. In initial efforts, carbon block material and boron oxide melt, $\mathrm{B}_{2} \mathrm{O}_{3}$, was contained in a stainless steel crucible that was placed in the pressure vessel. It was heated to $820-900{ }^{\circ} \mathrm{C}$. A sample of amorphous carbon block material was suspended above the melt. The sealed vessel was evacuated, then the evacuated sample submerged in the melt. Pressure was increased to $150 \mathrm{psi}$ and held at this pressure for 8 hours, at the high temperature. No penetration of the sample by the boron oxide was achieved. Impregnation may actually be made difficult by the increased surface tension of the melt.

Successful impregnation was achieved when sodium tetraborate (waterfree borax), $\mathrm{Na}_{2} \mathrm{~B}_{4} \mathrm{O}_{7}$, was added to the boron oxide melt. Minor quantities were sufficient to reduce the viscosity, to achieve satisfactory penetration. A content of $3 w t \% \mathrm{Na}_{2} \mathrm{~B}_{4} \mathrm{O}_{7}$ became the standard addition. It was, furthermore, found that an evacuation preceding the impregnation was not necessary.

\section{Laboratory Exposure Studies}

Samples of various boron oxide content were exposed to molten aluminum metal containing various amounts of titanium. Often a two-phase system (bath and metal) was employed. The aluminum was obtained from NSA, while the bath was obtained from Century Aluminum of West Virginia. Wetting was observed phenomenologically and examined by microscopic observation and SEM analysis. Experiments were rather simple exposure tests, as illustrated in Figure 5. 
Figure 5: Testing of laboratory samples.

\section{Laboratory Set-up}

Sample size:

Diameter $3.0 \mathrm{~cm}$

Length $10.0 \mathrm{~cm}$

Laboratory Testing

EMEC Consultants
15 February 2001

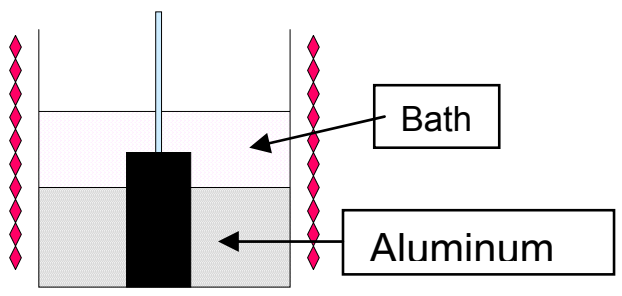

\section{Array for exposure in industrial pot}

Sample dimensions:

Diameter $5.0 \mathrm{~cm}$

Length $15 \mathrm{~cm}$

NSA Test Array

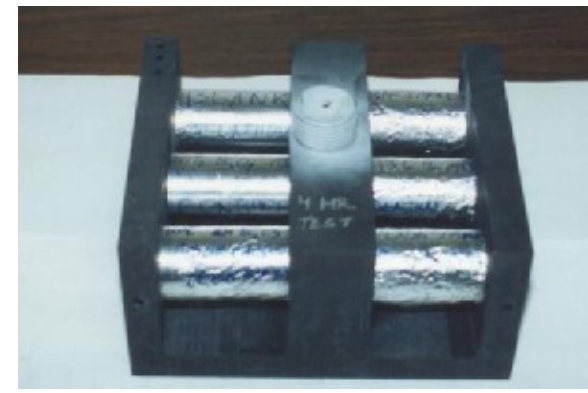

Parameters varied were:

Content of boron oxide in the samples

Concentration of titanium in the aluminum metal

Exposure time

The temperature was $960{ }^{\circ} \mathrm{C}$.

Boron oxide for this Phase I testing was supplied on a complimentary basis from U. S. Borax Inc. It was available in a 60 mesh technical grade, preferably used for mixing into green or ramming paste; a 4 mesh grade was more conveniently used to prepare melts.

After preliminary testing, which predominantly was conducted with ramming paste samples, testing was extended and included repetitive data. Four levels of titanium concentration in the metal were used. The wetting of the carbon after the exposure was observed visually and rated on a scale from 1 to 10 :

0 - 1: no evidence of wetting

2 - 4: wetting questionable

5 - 6: partial wetting 7 - 10: good wetting

The results of different samples exposed to the aluminum are shown in Tables 1 and 2 . 
Table 1: Results obtained with mixed ramming paste carbon samples containing boron oxide.

\begin{tabular}{||c|c|c|c|c||}
\hline $\begin{array}{c}\mathrm{Ti} / \mathrm{B}_{2} \mathrm{O}_{3} \\
(\mathrm{wt} \%)\end{array}$ & $0 \%$ & $5 \%$ & $10 \%$ & $20 \%$ \\
\hline $0.00 \%$ & $0 ; 0$ & $0 ; 0$ & $1 ; 1$ & $1 ; 1$ \\
\hline $0.05 \%$ & $0 ; 0$ & $0 ; 0$ & $2 ; 6 ; 7$ & $3 ; 9 ; 4$ \\
\hline $0.1 \%$ & $0 ; 0$ & $0 ; 0$ & $6 ; 0 ; 2$ & $7 ; 5 ; 1$ \\
\hline $0.5 \%$ & $1 ; 2$ & $8 ; 7$ & $7 ; 5 ; 6$ & $8 ; 9 ; 1$ \\
\hline
\end{tabular}

Table 2: Results obtained with impregnated and non-impregnated samples of graphitized and amorphous carbon matrix.

Impregnated samples:

\begin{tabular}{||c|c|c|c||}
\hline Ti wt\% & graphitized & $\begin{array}{c}\text { amorphous carbon } \\
50 \% \text { graphite }\end{array}$ & $\begin{array}{c}\text { amorphous carbon } \\
30 \% \text { graphite }\end{array}$ \\
\hline $0.00 \%$ & $1 ; 1$ & $1 ; 0$ & $2 ; 2$ \\
\hline $0.05 \%$ & $8 ; 5 ; 5$ & $4 ; 3$ & $2 ; 3 ; 1$ \\
\hline $0.1 \%$ & 8 & $8 ; 8$ & $8 ; 8 ; 9$ \\
\hline $0.5 \%$ & 8 & $4 ; 4$ & $7 ; 4 ; 3$ \\
\hline
\end{tabular}

Non-impregnated (blank) samples:

\begin{tabular}{||c|c|c|c||}
\hline \hline Ti wt\% & graphitized & $\begin{array}{c}\text { amorphous carbon } \\
50 \% \text { graphite }\end{array}$ & $\begin{array}{c}\text { amorphous carbon } \\
30 \% \text { graphite }\end{array}$ \\
\hline $0.00 \%$ & $0 ; 0$ & $0 ; 0$ & $0 ; 0$ \\
\hline $0.05 \%$ & $0 ; 0$ & $0 ; 0$ & $0 ; 0$ \\
\hline $0.1 \%$ & $0 ; 0$ & $0 ; 1$ & $0 ; 0$ \\
\hline $0.5 \%$ & $0 ; 0$ & $0 ; 3$ & $1 ; 5$ \\
\hline
\end{tabular}


In the initial phase of this program, it was thus determined that wetting by aluminum containing titanium could be obtained on samples prepared from ramming paste with boron oxide at the $10 \mathrm{wt} \%$ and $20 \mathrm{wt} \%$ level. It appeared that the boron oxide content should be relatively high, while the titanium concentration in the metal could be relatively low.

To arrive at optimal conditions, additional, systematic testing was conducted. Samples containing at least about $10 \mathrm{wt} \%$ boron oxide (by addition or impregnation) exposed to aluminum with $0.1 \mathrm{wt} \%$ titanium consistently showed wetting.

\section{Rapoport Tests (Sodium Intercalation).}

From thermodynamic data it had been projected that the presence of boron oxide may suppress sodium penetration (intercalation) into the carbon block material ${ }^{15}$. Results from Rapoport tests, performed at the laboratories of SGL Carbon in Germany, did not support this presumption. Impregnated amorphous samples actually showed a somewhat higher tendency to swelling and this appeared to apply also to block mix and ramming paste samples (the later displayed unfavorable behavior even without boron oxide addition, however).

It was shown in exposure tests (see later) that the uptake of sodium was fast even in the presence of boron oxide.

\section{Tests in Commercial Cells.}

Samples of cathode carbon containing various amounts of boron oxide, including some without additive serving as blank samples, were exposed to the metal pool of industrial cells. Exposure tests of samples mounted into a graphite block and dipped into the metal pool were conducted at NSA in Hawesville, Kentucky, and at Northwest Aluminum in The Dalles, Oregon. Once exposed, the arrays were transferred to EMEC Consultants for analysis. Table 3 lists the various tests, samples, and titanium content of the metal, as well as, the wetting characteristics of the recovered samples. At Century Aluminum in Ravenswood, West Virginia, samples were mounted into a cathode block and were examined after a month of exposure in the newly relined pot.

15 "Potlining Additives", Aluminum Project Fact Sheet, Published by the Office of Industrial Technologies, U.S. Department of Energy (1999). 
Table 3: Phase I industrial cell tests

\begin{tabular}{|c|c|c|c|c|c|}
\hline Test & Date/Duration & Sample Type & $\underline{\mathrm{B}}_{2} \underline{\mathrm{O}}_{3} \underline{\mathrm{Wt}} \%$ & $\mathrm{Ti}$ & Result \\
\hline $\begin{array}{l}1-92_{1} \\
\text { NSA }\end{array}$ & $\begin{array}{l}7 / 19 / 99 \\
4 \text { hours }\end{array}$ & $\begin{array}{l}\text { Amorphous 50\% Graphite } \\
\text { Block Mix } \\
\text { Block Mix } \\
\text { Graphitized } \\
\text { Amorphous 30\% Graphite } \\
\text { Amorphous 50\% Graphite }\end{array}$ & $\begin{array}{l}0.00 \\
20.0 \\
10.0 \\
10.3 \\
9.02 \\
13.6 \\
\end{array}$ & $\begin{array}{l}0.10 \\
0.10 \\
0.10 \\
0.10 \\
0.10 \\
0.10 \\
\end{array}$ & $\begin{array}{l}\text { Clean } \\
\text { Good Wetting } \\
\text { Wetted } \\
\text { Wetted } \\
\text { Wetted } \\
\text { Wetted } \\
\end{array}$ \\
\hline $\begin{array}{l}1-92_{2} \\
\text { NSA }\end{array}$ & $\begin{array}{l}\text { 7/19/99 } \\
7 \text { Days }\end{array}$ & $\begin{array}{l}\text { Ramming Paste } \\
\text { Block Mix } \\
\text { Block Mix } \\
\text { Graphitized } \\
\text { Amorphous } 30 \% \text { Graphite } \\
\text { Amorphous 50\% Graphite }\end{array}$ & $\begin{array}{l}10.0 \\
20.0 \\
10.0 \\
14.5 \\
9.60 \\
13.2 \\
\end{array}$ & $\begin{array}{l}0.10 \\
0.10 \\
0.10 \\
0.10 \\
0.10 \\
0.10 \\
\end{array}$ & All Wetted Well \\
\hline $\begin{array}{l}1-118 \\
\text { NSA }\end{array}$ & $\begin{array}{l}\text { 10/11/99 } \\
7 \text { Days }\end{array}$ & $\begin{array}{l}\text { Ramming Paste } \\
\text { Block Mix } \\
\text { Block Mix } \\
\text { Amorphous 30\% Graphite } \\
\text { Amorphous 50\% Graphite } \\
\text { Graphitized }\end{array}$ & $\begin{array}{l}10.0 \\
10.0 \\
10.0 \\
10.8 \\
14.2 \\
13.8\end{array}$ & $\begin{array}{l}0.025 \\
0.025 \\
0.025 \\
0.025 \\
0.025 \\
0.025 \\
\end{array}$ & $\begin{array}{l}\text { Worn Away } \\
\text { All Samples Worn } \\
\text { BN Broken }\end{array}$ \\
\hline $\begin{array}{l}1-119 \\
\text { NSA }\end{array}$ & $\begin{array}{l}\text { 10/19/99 } \\
7 \text { Days }\end{array}$ & $\begin{array}{l}\text { Block Mix } \\
\text { Block Mix } \\
\text { Amorphous 50\% Graphite } \\
\text { Amorphous 30\% Graphite } \\
\text { Graphitized } \\
\text { Graphitized }\end{array}$ & $\begin{array}{l}10.0 \\
20 \\
0.00 \\
10.7 \\
13.4 \\
14.2 \\
\end{array}$ & $\begin{array}{l}0.05 \\
0.05 \\
0.05 \\
0.05 \\
0.05 \\
0.05\end{array}$ & $\begin{array}{l}\text { Lost } \\
\text { Lost } \\
\text { All Samples Worn }\end{array}$ \\
\hline $\begin{array}{l}1-120 \\
\text { NSA }\end{array}$ & $\begin{array}{l}11 / 8 / 99 \\
5 \text { Days }\end{array}$ & $\begin{array}{l}\text { Amorphous } 50 \% \text { Graphite } \\
\text { Amorphous } 50 \% \text { Graphite } \\
\text { Graphitized } \\
\text { Graphitized }\end{array}$ & $\begin{array}{l}0.00 \\
13.2 \\
0.00 \\
13.1 \\
\end{array}$ & $\begin{array}{l}0.008 \\
0.008 \\
0.008 \\
0.008 \\
\end{array}$ & Entire Array Lost \\
\hline $\begin{array}{l}1-121 \\
\text { NSA }\end{array}$ & $\begin{array}{l}12 / 14 / 99 \\
5 \text { Days }\end{array}$ & $\begin{array}{l}\text { Amorphous 30\% Graphite } \\
\text { Amorphous 30\% Graphite } \\
\text { Graphitized } \\
\text { Graphitized }\end{array}$ & $\begin{array}{l}0.00 \\
10.4 \\
0.00 \\
13.4 \\
\end{array}$ & $\begin{array}{l}0.008 \\
0.008 \\
0.008 \\
0.008 \\
\end{array}$ & $\begin{array}{l}\text { None Wetted } \\
\text { All Samples Intact }\end{array}$ \\
\hline $\begin{array}{l}1-124 \\
\text { NSA }\end{array}$ & $\begin{array}{l}\text { 12/19/99 } \\
5 \text { Days }\end{array}$ & $\begin{array}{l}\text { Graphitized } \\
\text { Amorphous 30\% Graphite } \\
\text { Graphitized } \\
\text { Amorphous } 50 \% \text { Graphite }\end{array}$ & $\begin{array}{l}15.4 \\
8.83 \\
0.00 \\
0.00 \\
\end{array}$ & $\begin{array}{l}0.025 \\
0.025 \\
0.025 \\
0.025 \\
\end{array}$ & $\begin{array}{l}\text { Not Wetted } \\
\text { Not Wetted } \\
\text { Clean } \\
\text { Clean } \\
\end{array}$ \\
\hline $\begin{array}{l}1-128 \\
\text { NSA }\end{array}$ & $\begin{array}{l}1 / 5 / 00 \\
5 \text { Days }\end{array}$ & $\begin{array}{l}\text { Graphitized } \\
\text { Graphitized } \\
\text { Amorphous } 50 \% \text { Graphite } \\
\text { Graphitized }\end{array}$ & $\begin{array}{l}16.6 \\
13.03 \\
13.8 \\
0.00 \\
\end{array}$ & $\begin{array}{l}0.05 \\
0.05 \\
0.05 \\
0.05 \\
\end{array}$ & $\begin{array}{l}\text { Good Wetting } \\
\text { Good Wetting } \\
\text { Lost } \\
\text { Lost }\end{array}$ \\
\hline $\begin{array}{l}1-136 \\
\text { NSA }\end{array}$ & $\begin{array}{l}2 / 11 / 00 \\
5 \text { Days }\end{array}$ & $\begin{array}{l}\text { Graphitized } \\
\text { Graphitized } \\
\text { Amorphous 30\% Graphite } \\
\text { Amorphous 30\% Graphite }\end{array}$ & $\begin{array}{l}17.5 \\
0.00 \\
8.50 \\
0.00 \\
\end{array}$ & $\begin{array}{l}0.038 \\
0.038 \\
0.038 \\
0.038 \\
\end{array}$ & $\begin{array}{l}\text { Good Wetting } \\
\text { Clean } \\
\text { Good Wetting } \\
\text { Clean } \\
\end{array}$ \\
\hline $\begin{array}{l}\text { 1-139 } \\
\text { Northwest Al. }\end{array}$ & $\begin{array}{l}4 / 3 / 00 \\
5 \text { Days }\end{array}$ & $\begin{array}{l}\text { Amorphous 30\% Graphite } \\
\text { Amorphous 30\% Graphite } \\
\text { Graphitized } \\
\text { Graphitized }\end{array}$ & $\begin{array}{l}0.00 \\
10.8 \\
0.00 \\
14.1 \\
\end{array}$ & $\begin{array}{l}0.032 \\
0.032 \\
0.032 \\
0.032 \\
\end{array}$ & $\begin{array}{l}\text { Clean } \\
\text { Good Wetting } \\
\text { Clean } \\
\text { Good Wetting }\end{array}$ \\
\hline $\begin{array}{l}\text { 1-152 } \\
\text { Northwest Al. }\end{array}$ & $\begin{array}{l}5 / 29 / 00 \\
5 \text { Days }\end{array}$ & $\begin{array}{l}\text { Amorphous 30\% Graphite } \\
\text { Amorphous 30\% Graphite } \\
\text { Graphitized } \\
\text { Graphitized }\end{array}$ & $\begin{array}{l}0.00 \\
6.63 \\
0.00 \\
15.8 \\
\end{array}$ & $\begin{array}{l}0.020 \\
0.020 \\
0.020 \\
0.020 \\
\end{array}$ & $\begin{array}{l}\text { Bath-covered } \\
\text { Not Wetted } \\
\text { Bath-covered } \\
\text { Partial Wetting }\end{array}$ \\
\hline
\end{tabular}

Note: clean refers to samples with no boron oxide, while not wetted refers to samples containing boron oxide. 


\section{Tests at NSA}

The test array was described previously in Figure 5; it was later modified to hold four samples only. Exposed sample combinations are listed in Table 3.

Two exposure tests were conducted in July 1999, and, three tests, each in early October, late October and early November 1999, were conducted, as well. The first four arrays were constructed using the original design. In October, however, two arrays failed during the testing in the industrial cell. The boron nitride section broke from the carbon block, thus allowing the carbon to float and move into the bath layer. When this occurred, the block and samples were no longer in the metal pool and no metal would wet the samples.

The failures in the two October exposures prompted a redesign of the sample array. The test in early November was conducted with an array that was modified to be better supported, while four samples instead of six were exposed. The boron nitride piece was threaded directly into the carbon block, and overall better care of the array was exercised by NSA. Nevertheless, the entire block was lost in the cell.

The arrays to this point were of a design that consisted of a block that was machined into a rectangular " $U$ " shape and the samples were attached on both sides. In the month of December 1999 two exposure tests were completed with a block that was constructed in much the same way except that the outer wall of the "U" was removed. Therefore, the samples were threaded only into the block on one side.

The first exposure in December was for 5 days, and no titanium was added to the metal pool (the content was a relatively high $0.008 \mathrm{wt} \%$ ), as to test the new array with as little inconvenience to NSA as possible. The array was removed after 5 days and all of the samples were recovered and the new design seemed to be viable for further testing.

The second exposure test in December utilized the same design exposed for 5 days in the metal pool containing $0.025 \mathrm{wt} \%$ titanium. The samples were again recovered, but the samples and the array may have been at least partially in sludge.

NSA conducted two more tests, utilizing the same block design used in December 1999. The first of these final two exposure tests was conducted in early January 2000. There were four samples exposed to a metal pool containing $0.05 \mathrm{wt} \%$ titanium. The array was recovered, but two samples were lost. There appeared to be some sludge on the array, and it is thought that at least part of the array was in the sludge. The two 
samples that were recovered, however, were the impregnated samples that could be examined for wetting results.

The final test at NSA was completed in early February 2000. The same array design was utilized and exposed in the metal pool containing $0.038 \mathrm{wt} \%$ titanium. Again four samples were exposed; the array with all four samples was recovered. Conclusive results could be obtained. This final exposure showed that this design worked well and yielded valuable results.

\section{Exposure Testing at Northwest Aluminum Company}

Two exposure tests were conducted at the Northwest Aluminum Company smelter in The Dalles, Oregon. The NWA cells have a deeper metal pool than the pots at NSA, and a new array design was utilized. The exposure of these samples was actually made easier by the deeper metal pool because there is less of a chance of coming in contact with sludge or bath. This test array, before, during and after exposure, is shown in Figure 6.

The first test was conducted in April 2000. The metal pool contained $0.032 \mathrm{wt} \% \mathrm{Ti}$ (initially) to $0.025 \mathrm{wt} \%$ (ending value). Intact samples were recovered after 5 days. Differences in appearance between samples impregnated with boron oxide (upper two samples) and blank samples (lower row) is recognizable in Figure 6. Cross sections are shown later in the discussion of wetting characteristics. They clearly indicate the adherence of metal to the carbon surface in the case of impregnated samples, while blank samples were just covered with some frozen bath.

A second test was conducted in May 2000, with a lower titanium content of $0.020 \mathrm{wt} \%$ in the aluminum pool. Results were less conclusive, as substantial partial wetting was indicated for the impregnated graphitized sample but not for the amorphous counter part. According to analysis, the amorphous sample, for unidentified reasons, had a substandard boron oxide content (see Table 3). 
Figure 6: Testing of array of samples at NWA.

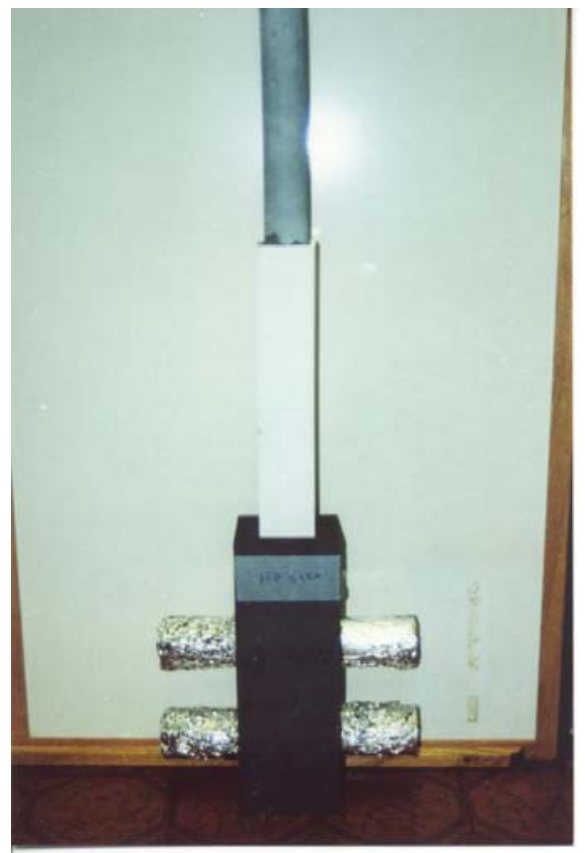

Array ready for exposure

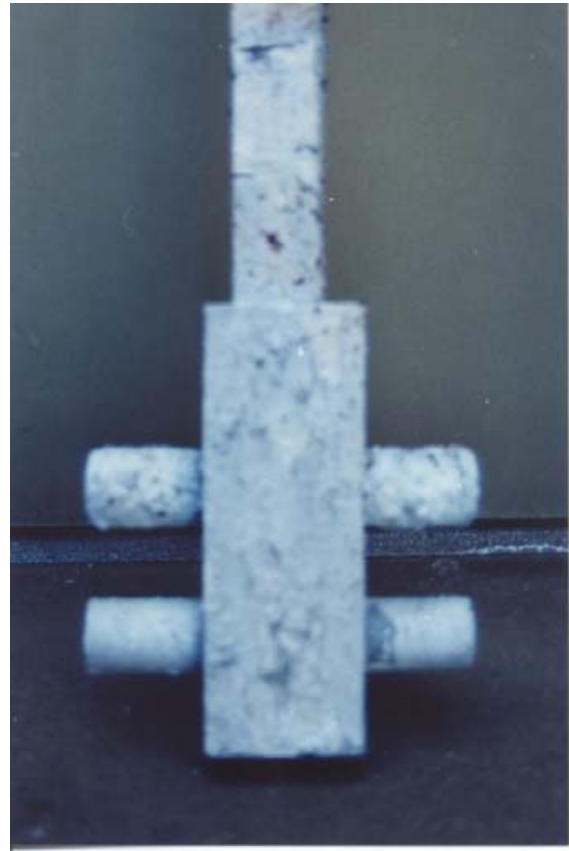

Array after exposure

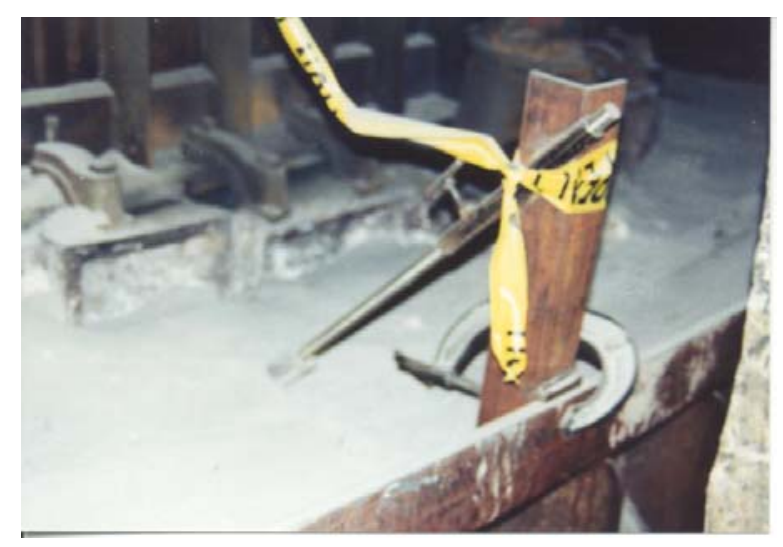

Array mounted in cell during exposure 


\section{Testing at Century Aluminum of West Virginia}

A one-month Phase I exposure test was started on 14 July 2000 in a cell of the Century Aluminum plant in Ravenswood, West Virginia.

The following samples were provided by EMEC Consultants:

Amorphous, $50 \%$ graphite (Century Aluminum), impregnated with $\mathrm{B}_{2} \mathrm{O}_{3}$

Amorphous, $30 \%$ graphite (SGL Carbon), impregnated with $\mathrm{B}_{2} \mathrm{O}_{3}$

Graphitized (SGL Carbon), impregnated with $\mathrm{B}_{2} \mathrm{O}_{3}$

Ramming paste mixed with $10 \mathrm{wt} \% \mathrm{~B}_{2} \mathrm{O}_{3}$ (prepared by Century Aluminum)

Block mix containing $10 \mathrm{wt} \% \mathrm{~B}_{2} \mathrm{O}_{3}$ (prepared by Century Aluminum)

Graphitized (SGL Carbon), blank sample

Amorphous, $30 \%$ graphite (SGL Carbon), blank sample

- Graphitized (SGL Carbon), impregnated with $\mathrm{B}_{2} \mathrm{O}_{3}$, with end of sample cut

The samples were 2 inches $(5 \mathrm{~cm})$ in diameter and 6 inches $(15 \mathrm{~cm})$ in length.

Precision Inc. in Sistersville, West Virginia, mounted them into core-drilled holes of a standard cathode block, such that the end face would be exposed to the metal pool.

The cell was started following Century's standard procedure. The cathode carbon was first exposed to electrolyte that was added to the cell, later to metal containing no titanium. Titanium was added to the aluminum on 17 July 2000. A titanium content of $0.05 \mathrm{wt} \%$ in the metal pool was targeted. This level was maintained by adding an appropriate amount of titanium every time after tapping. The experiment was terminated in the month of August 2000. Results were evaluated in cooperation with EMEC Consultants.

Once the pot was shutdown, the metal and bath were removed in order to examine the resulting surface and core-drill the samples from the cathode blocks. There was no wetting of the samples that could be detected, and analysis of the samples showed that there was little boron oxide remaining in the samples. The boron oxide was apparently leached out into the mass of cathode material that did not contain any boron oxide. There was, however, less wear observed on EMEC Consultants' samples as compared to the normal blocks that were in the pot (which showed an abnormally high wear). The samples appeared to protrude slightly from the surface of the cathodes.

\section{Retention of Boric Oxide}

Boron and sodium contents in exposed samples were determined by the Pittsburgh Lab of Quanterra Inc. (now STL, Severn Trent Services). Their values for boron contents indicated that the samples contained boron essentially uniformly throughout the sample. 
They further indicated that boron oxide was not leached out of the sample in significant amounts in samples tested at NSA; the boron oxide component was retained in the samples. Lower boron contents were reported for samples tested at NWA, indicating that some boron oxide leached out of the samples. Analysis results obtained by the method employed by Quanterra, however, were later found unreliable.

\section{Sodium Intercalation and Carbide Formation}

Chemical analysis for sodium content indicated that substantial amounts of sodium had intercalated to a uniform concentration after a week's exposure (not so after 4 hours). Sodium pick-up was about twice as large for amorphous material $(6.4 \%)$ as for a graphitized sample (4.2\%).

Gas formation was observed on samples in humid laboratory air. While it was assumed that gas from inner areas of a sectioned sample was due to reaction of sodium with water, there was also the possibility of aluminum carbide forming methane, particularly as yellow discoloration was observed at the interface of metal and carbon. Samples were exposed to distilled water and the evolving gas collected for gas analysis, which was performed by Advanced Technology Systems, Inc. (ATS), Pittsburgh.

The samples tested were amorphous materials containing 30 and $50 \%$ graphite, respectively, and a graphitized material; all were impregnated with boron oxide and exposed for one week at NSA $(0.10 \% \mathrm{Ti}$ in the metal). The gas samples were analyzed for oxygen, nitrogen, methane and hydrogen. The samples all produced methane and hydrogen, with $\mathrm{CH}_{4} / \mathrm{H}_{2}$ ratios being about 0.6 for amorphous samples and 4.4 for a graphitized sample. Consistent with analyses for sodium content, the hydrogen evolution was less pronounced in the graphitized sample than in the amorphous samples; also a stronger tendency to carbide formation was indicated for graphitized samples.

\section{Wetting Characteristics}

Striking differences between samples impregnated with boron oxide and blank samples could already be observed when removing samples at the end of the exposure period from the industrial cell: blank samples emerged with a thin bath layer only, while impregnated samples were covered by a thicker layer, which contained metal adhering to the carbon. Cross-sectioned samples confirmed the difference, as exemplified in Figure 7 for samples removed from a NWA cell after a 5-day test. 
Figure 7: Cross-section comparison of samples exposed in industrial cell (NWA).

graphitized samples

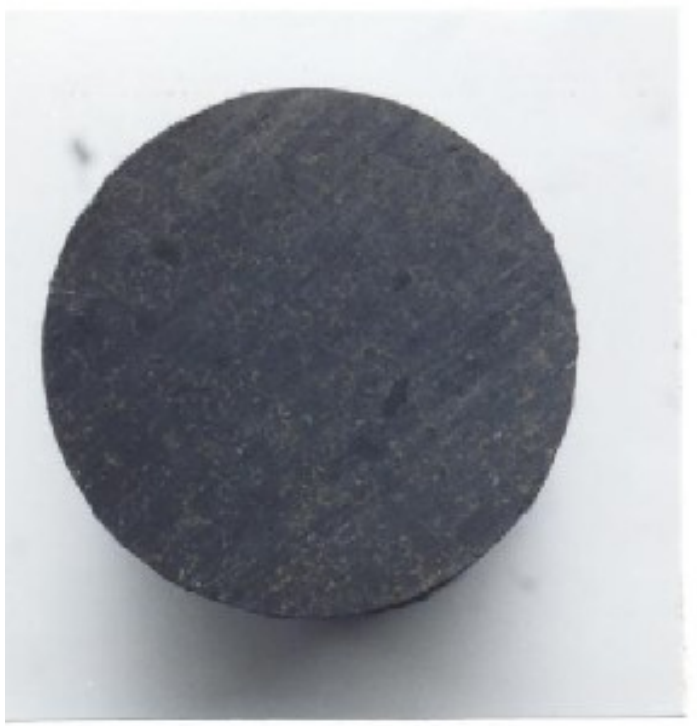

blank

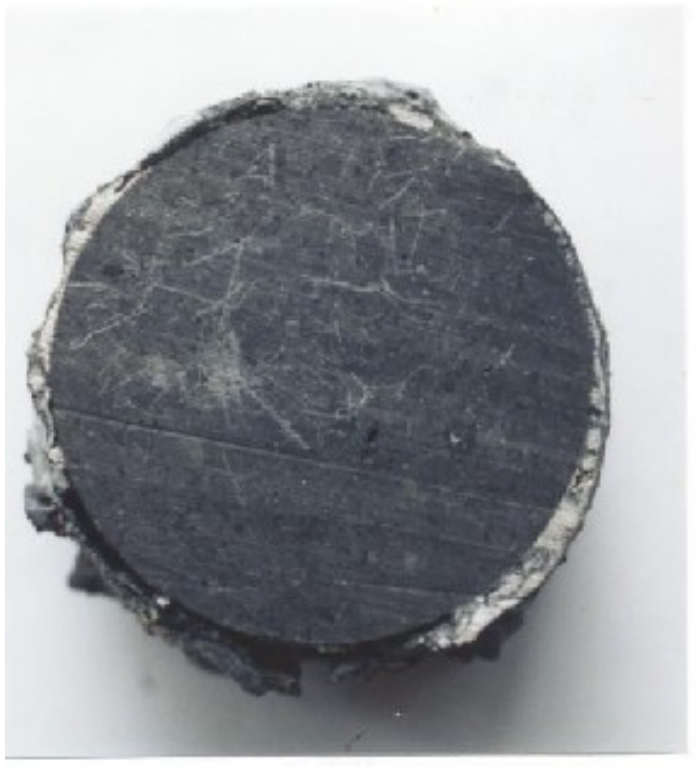

impregnated amorphous samples

( $30 \%$ graphite content)

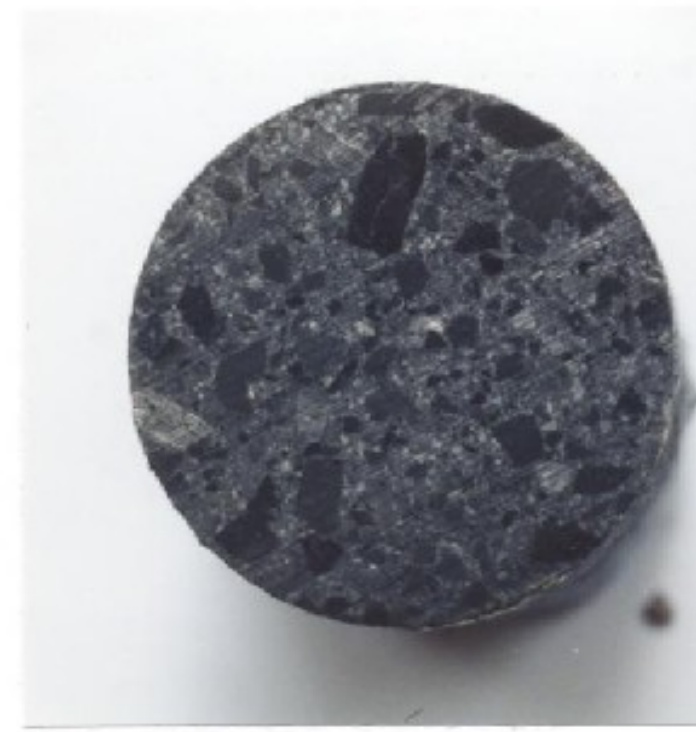

blank

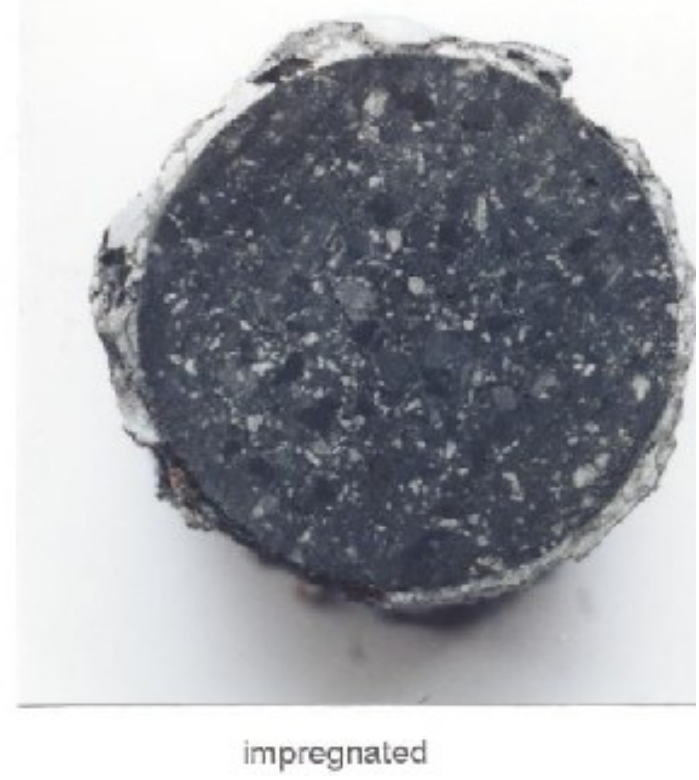


A consistent adherent metal layer was also found in tests at NSA, as Figure 8 shows. Two graphitized samples were exposed to metal containing $0.1 \mathrm{wt} \%$ titanium, one for four hours, the other for a week. Wetting was more consistent after the longer exposure time. Thus, the 1-week sample was covered by a relatively thick aluminum coating, which, however, was largely detached from the carbon substrate (which probably occurred on cooling because of differences in the thermal coefficient of expansion between the two materials). A block mix containing $20 \mathrm{wt} \% \mathrm{~B}_{2} \mathrm{O}_{3}$ was also clearly wetted, as particularly evidenced by metal protruding into a cavity. The other sample depicted in Figure 8 is an impregnated amorphous material; it again shows a pronounced coating. On this last picture, the formation of small gas bubbles and some oozing of a liquid phase can be seen -- probably the result of sodium or a species reduced by sodium reacting with moisture in the air to form hydrogen.

It is remarkable that consistent wetting could be found at titanium levels in the aluminum metal pool at concentrations as low as $0.025 \mathrm{wt} \%$. Originally, to enhance the chances to find this effect, experimentation at levels of $0.1 \mathrm{wt} \%$ and higher were planned.

At a level of $0.008 \mathrm{wt} \%$, however, wetting could not be found at a test conducted at NSA. This is not surprising, as one could expect that titanium diboride formed at these levels may, to a large extent, dissolve in the aluminum. Titanium diboride dissolves at $960{ }^{\circ} \mathrm{C}$, in the absence of excess titanium or boron, into the metal to a concentration of $56.5 \mathrm{mg} \mathrm{TiB} 2$ per $\mathrm{kg} \mathrm{Al}$ (corresponding to $38.9 \mathrm{mg} \mathrm{Ti}$ per $\mathrm{kg} \mathrm{Al}=0.00389 \mathrm{wt} \% \mathrm{Ti}$, and $17.6 \mathrm{mg} \mathrm{B}$ per $\mathrm{kg} \mathrm{Al}$ ), assuming a solubility product of $[\mathrm{Ti}][\mathrm{B}]^{2}=1.2 \times 10^{-8}(\mathrm{wt} \%)^{3}$, derived from an equation given by Finch ${ }^{11}$. 
Figure 8: Samples exposed at NSA showing an adherent metal layer.

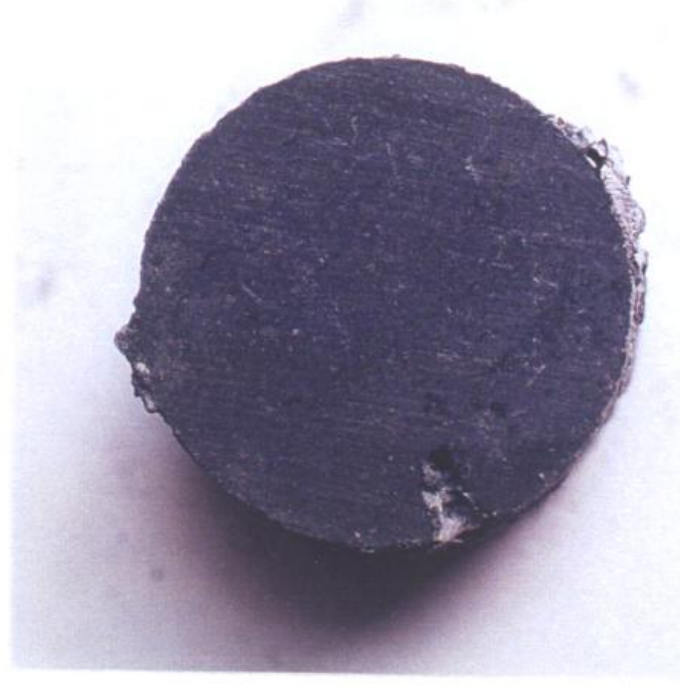

graphitized impregnated sample exposed for 4 hours

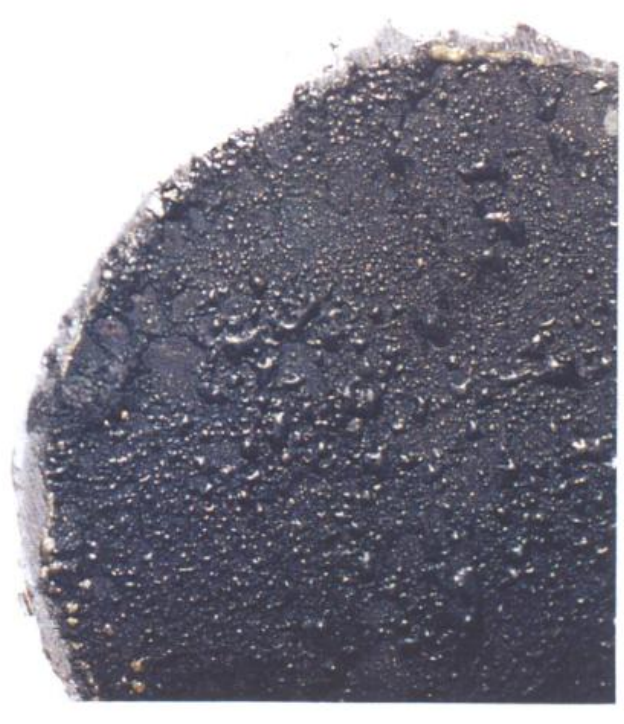

amorphous impregnated sample, exposed for 1 week

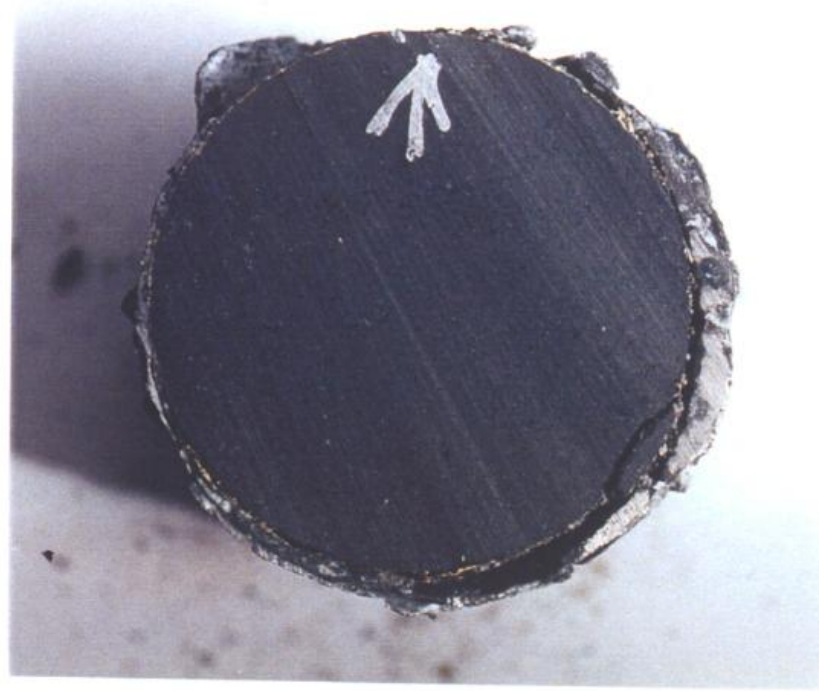

graphitized impregnated sample exposed for 1 week

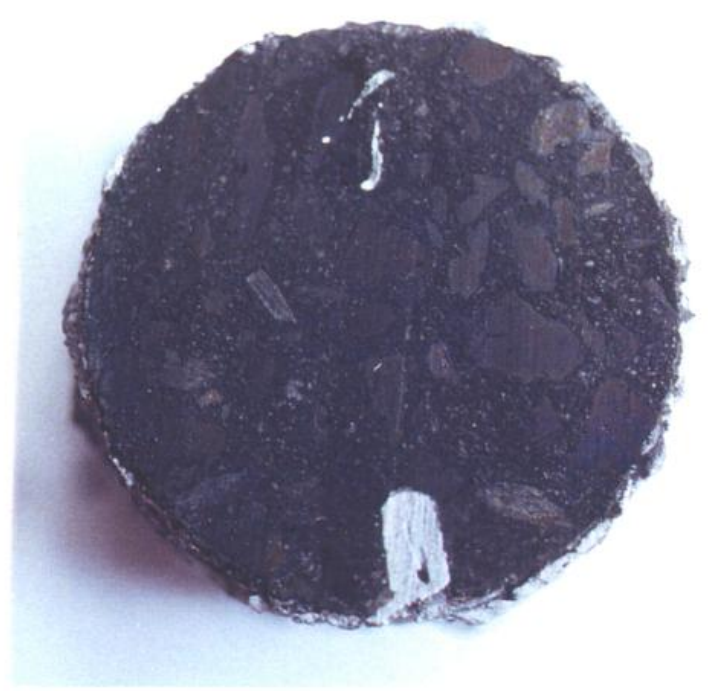

block mix sample with $20 \% \mathrm{~B}_{2} \mathrm{O}_{3}$, exposed for 1 week 


\section{SEM Studies}

Evidence of wetting of the cathode material was provided by a visual observation of an aluminum layer on the surface of the test piece. A more accurate procedure to determine if wetting has occurred is microscopic examination. In-depth analysis can be done by SEM (Scanning Electron Microscopy), which is particularly powerful in conjunction with an EDS (Energy Dispersive Spectroscopy) feature that permits spot analysis of the elemental composition. Boron, however, is too light an element to be detected by normal means, but special efforts were made to arrive at results including the determination of boron.

We are postulating, based on thermodynamic data, that boron oxide reacts with titanium in the metal to form titanium diboride, $\mathrm{TiB}_{2}$. This titanium diboride causes wetting of carbon by aluminum to occur. Accumulation of titanium and boron on or near the surface of the sample would indicate the formation of $\mathrm{TiB}_{2}$.

\section{Investigations at RJ Lee Group}

Several trips were made to RJ Lee Group in Monroeville, Pennsylvania, where samples were examined by Mr. John E. Stulga. Samples for these investigations were prepared at EMEC Consultants from exposure tests conducted in the lab and at the NSA smelter in Hawesville, Kentucky. Carbon block materials were a variety of block mix samples prepared at Century Aluminum of West Virginia. Amorphous samples were supplied by SGL Carbon (30\% graphite) and Century Aluminum (50\% graphite), and SGL Carbon provided graphitized samples; EMEC Consultants impregnated all of these samples.

Initial SEM examinations were conducted on samples that were exposed in laboratory experiments at EMEC Consultants using a titanium concentration of $0.50 \mathrm{wt} \%$ in the aluminum. Accumulation of titanium (presumably present as titanium diboride) was found in the metal phase. It was believed that these observations confirmed the wetting effect as a consequence of the formation of titanium diboride, $\mathrm{TiB}_{2}$, but this could not be proven conclusively by the examinations at RJ Lee Group.

Other samples were examined that were impregnated and exposed in an industrial cell at NSA. These samples were amorphous block containing $50 \%$ graphite, amorphous block containing $30 \%$ graphite, and graphitized blocks. All of these samples were exposed for one week to aluminum containing $0.10 \mathrm{wt} \%$ titanium. An example of such a SEM/EDS study is presented in Figure 9. Point $\langle 1\rangle$ is situated in an outer bath layer. The examination shows that there is an aluminum layer present which is enriched with titanium-containing particles $\langle 2\rangle\langle 3\rangle\langle 4\rangle$, while there is also an electrolyte layer $<5\rangle$ between the aluminum and the carbon $\langle 6\rangle$ as also seen in previously examined 
samples. Point $<7>$ represents bath penetrated into the carbon. The other samples generally all showed similar characteristics.

Figure 9: SEM/EDS examination of sample exposed in NSA industrial cell.
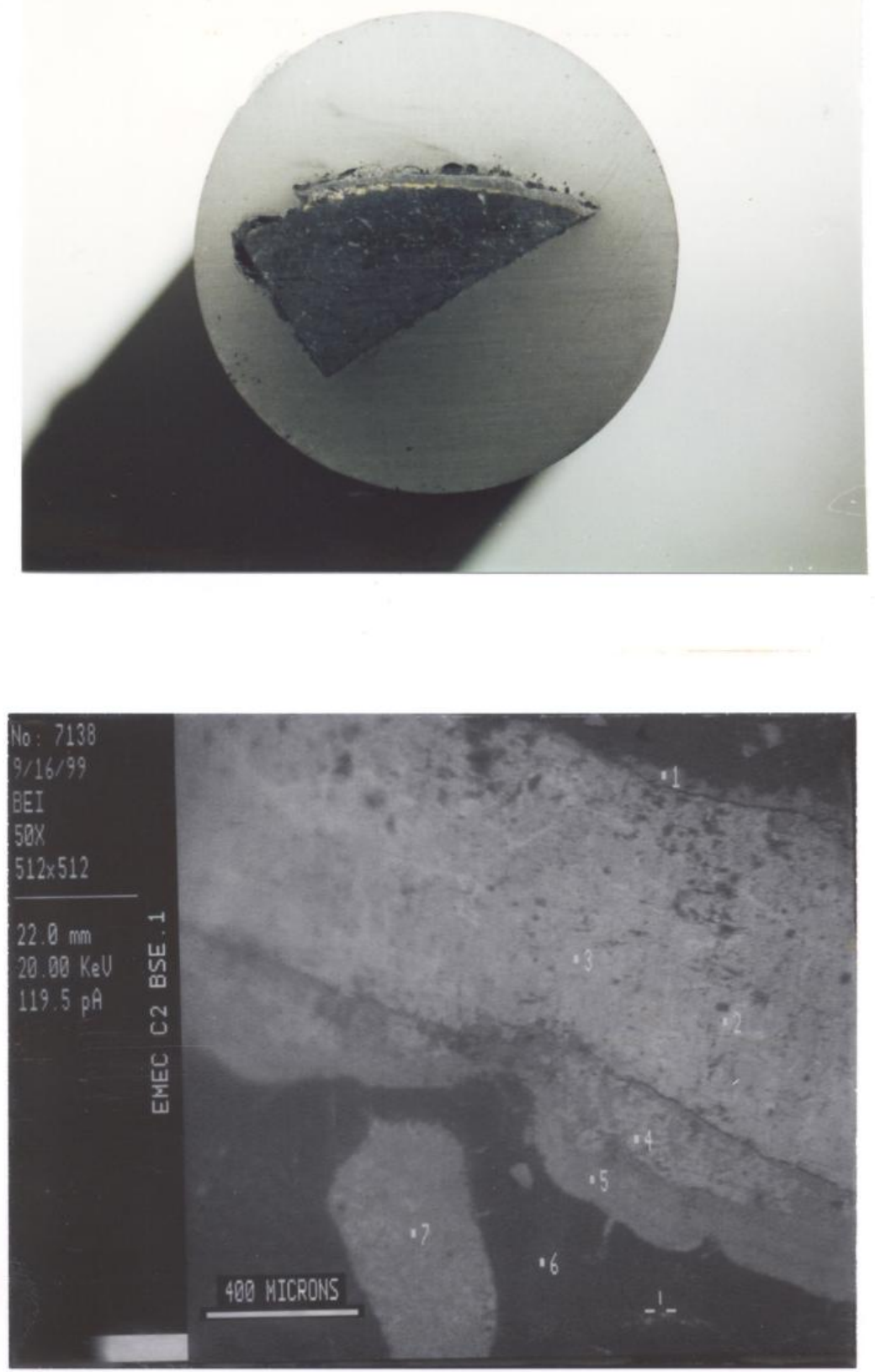

${ }^{*}$ Graphitized sample containing $14.5 \% \mathrm{~B}_{2} \mathrm{O}_{3}$, exposed for 7 days with $0.10 \% \mathrm{Ti}$. 
The samples exposed to the aluminum metal containing $0.038 \%$ titanium, however, did show an aluminum layer wetting the samples (graphitized and amorphous block with $30 \%$ graphite, both impregnated), and the aluminum layer contained an enrichment of titanium particles, with a bath layer between the aluminum and carbon.

The samples that were exposed at EMEC Consultants and NSA all were observed to have a bath (electrolyte layer) between the adhering aluminum layer and the carbon. Even though the aluminum contained the titanium enriching particles, the presence of this electrolyte layer between the aluminum and the carbon was somewhat troubling. Because of this, ramming paste samples containing $5 \mathrm{wt} \%$ and $20 \mathrm{wt} \%$ boron oxide were exposed to an aluminum melt with $0.50 \mathrm{wt} \%$ titanium, without the presence of any bath or electrolyte. These samples were exposed at EMEC Consultants and examined visually and with the SEM/EDS.

This examination of these samples indicated that the aluminum metal wetted the carbon and contained the titanium enriching particles with the $20-w t \%$ boron oxide containing sample. No titanium particles were discovered with the $5-w t \%$ boron oxide sample. Despite the absence of electrolyte, with the $20 \%$ boron oxide sample the aluminum layer was not in direct contact with the carbon, once again, but in this instance there was an oxygen-rich layer between the aluminum and the carbon. This oxygen-rich layer is thought to be boron oxide from the sample, as no other elements except oxygen were indicated in this layer. The boron could not be detected with the SEM/EDS equipment available. These observations further strengthen the assumption that the titanium actually represented $\mathrm{TiB}_{2}$ because the titanium particles formed adjacent to this oxygen rich (presumably boron oxide) layer. 


\section{PHASE II IMPREGNATION CAPABILITY AND LIMITED TESTS IN INDUSTRIAL CELLS}

\section{Method to Impregnate Cathode Blocks}

Laboratory-type tests were conducted to further establish favorable impregnation conditions and methods to clean cathode blocks after impregnation.

For the impregnation, the following method emerged as the standard procedure: Solid boron oxide with $3 \mathrm{wt} \%$ water-free borax is melted and heated to a temperature of $800^{\circ} \mathrm{C}$ in the Inconel crucible of a pressure vessel. The block to be impregnated, mounted in an Inconel "cage", is suspended over the melt in the upper part of the crucible and heated for a period of at least 4 hours. With the cover of the pressure vessel open, the block is lowered to the bottom of the vessel, to be completely covered with melt, with ample melt provided such that the block remains fully immersed during the course of impregnation of melt into the block. The autoclave is closed and pressure of $160 \mathrm{psi}(1.1 \mathrm{MPa})$ applied and maintained for 8 to 10 hours. After this period, the pressure is released, the vessel is opened and allowed to rest overnight, and the block remains completely immersed in the melt. The next day, the pressurized condition is reestablished and maintained for another 8 to 10 hours. After this final period, pressure is released, the vessel opened and the block withdrawn. Some melt may be scraped off before transfer of the block to a location where it is left for cooling.

The solidified melt can be removed from the surface of the block by cleaning with a descaling tool (needle gun). Weight determinations before exposure and after cleaning indicate the amount of melt impregnated into the block.

\section{Impregnation Equipment}

A high-temperature pressure vessel was designed and fabricated by Autoclave Engineers, Erie, Pennsylvania. It was designed to accommodate half-length blocks up to AP-30 size $(67 \mathrm{~cm} \times 45 \mathrm{~cm} \times 164 \mathrm{~cm})$. Although specifications allowed it to exceed the applied pressures and temperatures, the vessel was normally operated at about 800 ${ }^{\circ} \mathrm{C}$ and $160 \mathrm{psi}(1.1 \mathrm{MPa})$.

The design of the pressure vessel is illustrated in Figure 10. The vessel consisted of a steel shell that was externally cooled by circulating cooling fluid through attached cooling elements; the cooling fluid was circulated to an external heat exchange unit. A heating unit, manufactured by Thermcraft, Winston-Salem, North Carolina, was placed 
inside this pressurized shell, with appropriate insulation between shell and heater. An Inconel crucible (stainless steel upper part above the melt) was placed in the center of this heating unit and contained the melt. Cathode blocks were mounted in an Inconel "cage" and lowered into the melt. A screw-in cover that was water-cooled was used to close the vessel at the top.

The arrangement was placed in a 3-meter deep pit in the Warren Haupin Pilot Facility of EMEC Consultants in Arnold (New Kensington), Pennsylvania. Figure 11 shows the arrival of the vessel, its placement into the pit, and the withdrawal of an impregnated block.

Figure 10: Design of the pressure vessel.

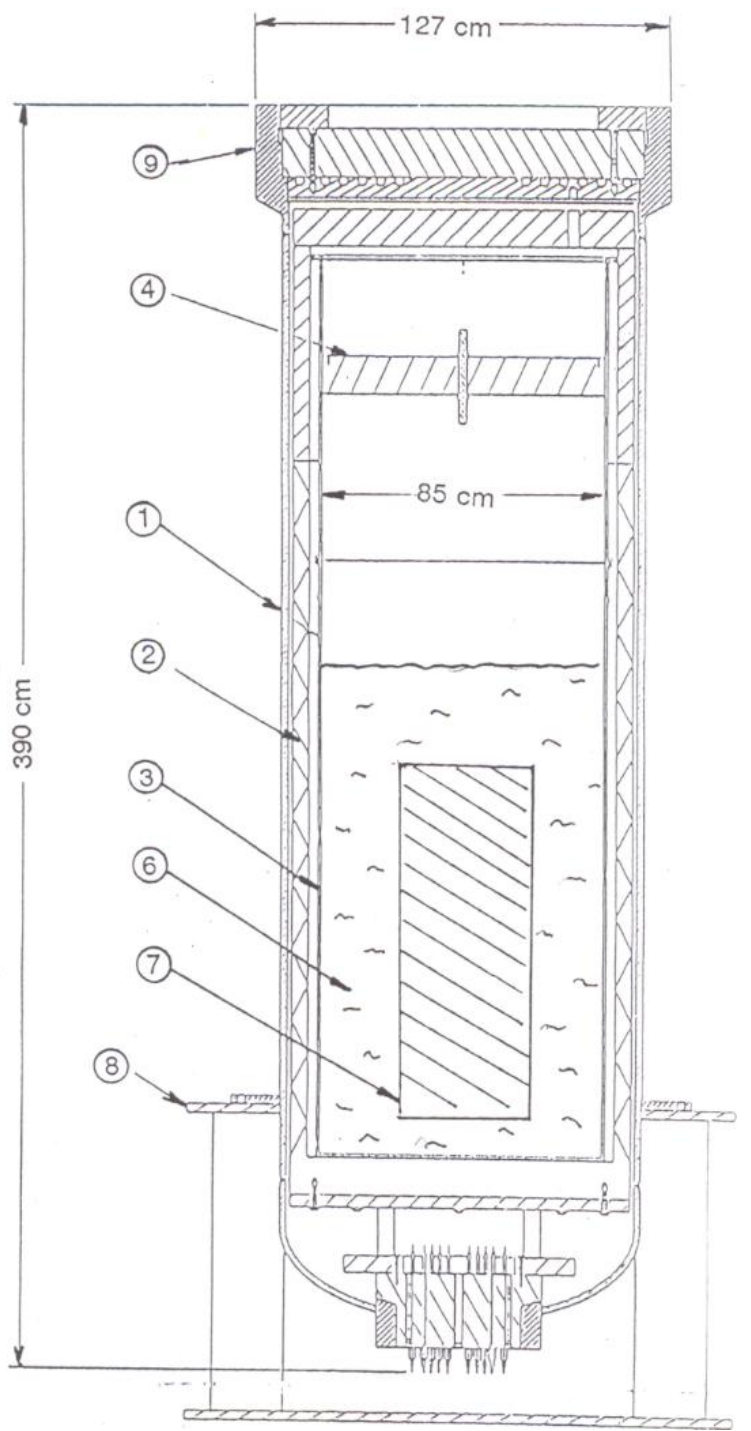

\author{
$<1>$ steel shell (pressure vessel), \\ covered with cooling elements \\ $<2>$ furnace unit, heating inside, \\ insulated towards shell \\ $<3>$ crucible, lower part Inconel, \\ upper part stainless steel \\ $<4>$ heat shield \\ $<5>$ screw-in cover, water-cooled \\ $<6>$ boron oxide melt \\ $<7>$ cathode block \\ $<8>$ support \\ $<9>$ cooled lid
}


Figure 11: Vessel arrival, installation, and block impregnation.

Right: Heating unit being lowered into the pressure vessel.

Below: Pressure vessel arriving at the Warren Haupin Pilot Facility.
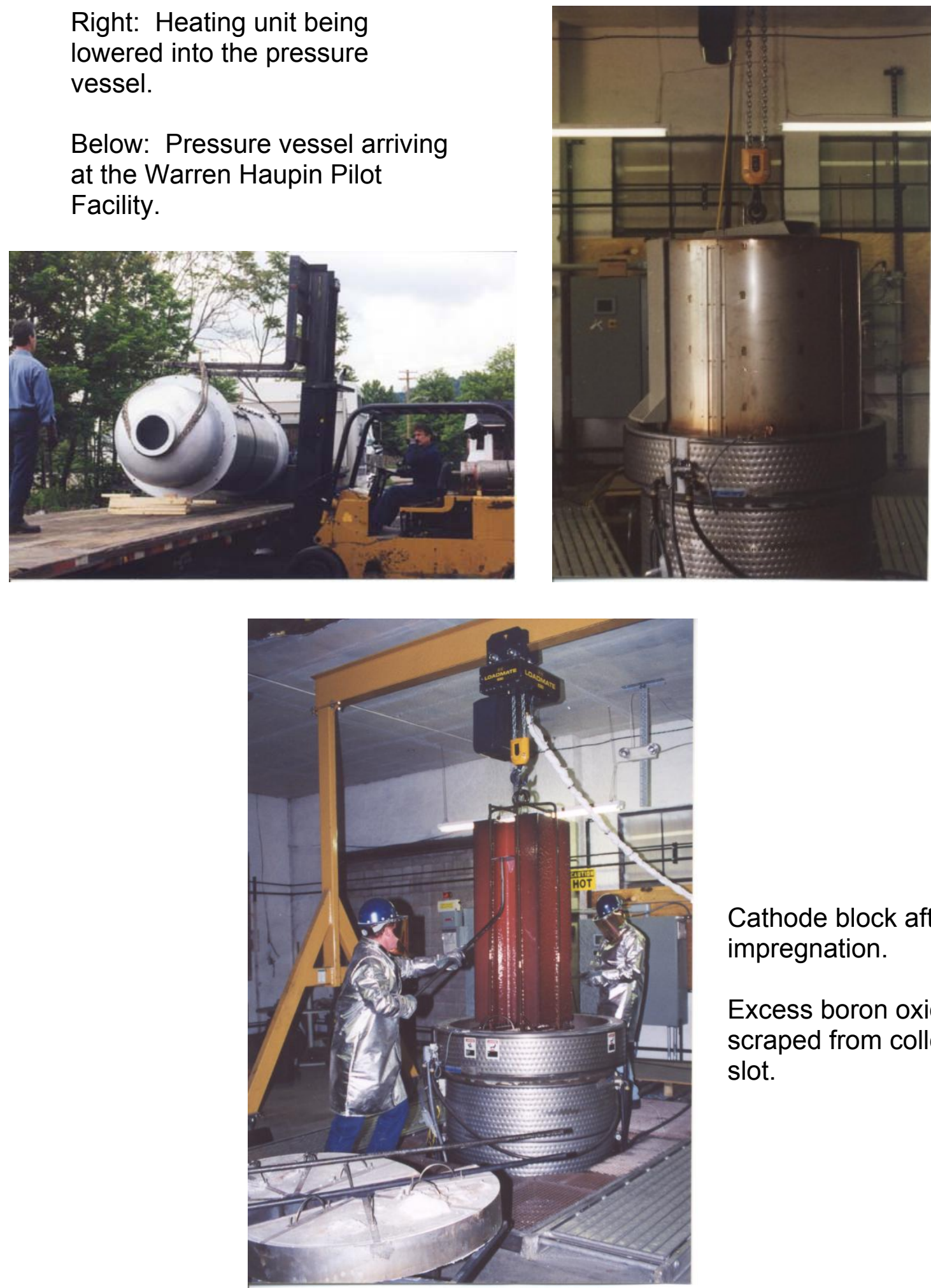

Cathode block after impregnation.

Excess boron oxide being scraped from collector bar slot. 
The equipment was delivered to the pilot facility, after substantial delays, on 4 June 2001. After the installation was completed, testing revealed shortcomings, and remediation was required. Heat transfer from the heating unit to the steel shell was initially excessive when the vessel was pressurized. It turned out that gas circulated by a "chimney effect" through the space between furnace unit and steel vessel; this circulation was stopped sufficiently by stuffing insulating material into the gap. Other shortcomings that plagued the operation of the unit repeatedly were insufficiently robust welded connections on the heating unit and thermocouple failures.

Special measures had to be taken to safeguard against damages caused by unscheduled power interruptions. As the circulation of the cooling liquid could not be stopped over prolonged periods without the cooled pressure vessel heating to damaging temperatures, a manual switchover to public water was planned. An alarm system (paging to external sites) to indicate failures during period of absence of personnel was installed.

\section{Industrial Tests with Ramming Paste Containing Boron Oxide in Seams}

A 6-month test with seams containing boron oxide was conducted at the NSA smelter in Hawesville, Kentucky (now Century Aluminum of Kentucky). In the partial autopsy (sampling by core-drilling) after six months of operation, the seams were found depressed by about 1 to 2 inches. This could have been caused by shrinkage of the ramming paste due to the presence of liquefying boron oxide, but an inferior quality of the ramming paste could not be ruled out. The lack of a reliable method to analyze for boron content hampered the further interpretation of results at this stage. It appears that substantial amounts of boron oxide were lost from the seams during cell operation.

\section{Industrial Tests with Impregnated Cathode Blocks}

Six half-length impregnated amorphous blocks were installed in a pot at the Century Aluminum plant in Ravenswood, West Virginia. The pot was started up on 14 December 2001. Bath was added first, and 16 hours later molten metal was added. Titanium was added afterwards to the metal pool and kept at a level of $0.05 \mathrm{wt} \%$ by periodic additions.

The pot was operated for six months, with daily additions of aluminum-titanium alloy to the metal pool. Shut down and partial autopsy were initiated on 13 June 2002. The appearance of the blocks showed a decisive difference between impregnated and nonimpregnated blocks; also blocks containing boron oxide were harder to core-drill. 
Samples of two-inch and four-inch $(5 \mathrm{~cm}$ and $10 \mathrm{~cm}$ ) diameter and 4 to 6 inches (10 to $15 \mathrm{~cm}$ ) in length were core-drilled at locations indicated in Figure 12. Samples were analyzed for boron and sodium content. Generally about half of the initial boron oxide content (as determined from weight gain upon impregnation) remained, with no significant difference between upper and lower parts of each sample. The remaining boron content appears to be sufficient to maintain a titanium diboride presence at the block-metal interface. Substantial losses of boron oxide may have occurred durring start-up due to exposure to bath. The sodium content (intercalated sodium and bath components) was somewhat higher in impregnated blocks. Boron oxide migrated into seams as was indicated by $5.89 \mathrm{wt} \%$ boron oxide found in a seam between two impregnated blocks where initially no boron oxide was present. Contents of boron oxide in lower parts of the blocks and in refractories beneath them could not be determined because the partial autopsy relied exclusively on core-drilled samples, as planned.

Attempts to attain indications for the wetting of the carbon by metal were not successful. Steel pipes of 4 inch diameter were lowered tightly against the carbon before tapping of the metal. Some metal was trapped but after solidification no adherence to carbon was evident. Neither could an accumulation of titanium due to the formation of titanium diboride be detected by scanning electron microscopy. It may have been the case that the relatively small amount of titanium diboride entered the bulk of the solidifying metal and then could not be detected.

Results of this Phase II test were encouraging insofar as boron oxide was evidently available at the block surface after a six-month period. Reliable measurements of currents going to individual blocks were not possible and projections in regard to pot performance could not be made.

The pot was subsequently restarted and is performing normally at the time this report is issued. Measurement of cathode voltage drops showed average values for the impregnated blocks, if anything they were rather somewhat lower.

Six half-length graphitized blocks were impregnated for a Phase II test at the Goldendale (Washington) plant of the Golden Northwest Aluminum Company. Due to discontinuation of operation at the Northwest Aluminum smelter in The Dalles, Oregon, testing in its sister company was suggested as an alternative. Goldendale, however, never got in the position to incorporate the impregnated blocks into a pot, and the entire production of primary metal has been halted at this plant. 
Figure 12: Layout of samples taken during partial autopsy.

13 JUNE 2002 PARTIAL CELL AUTOPSY AT CENTURY ALUMINUM OF WV

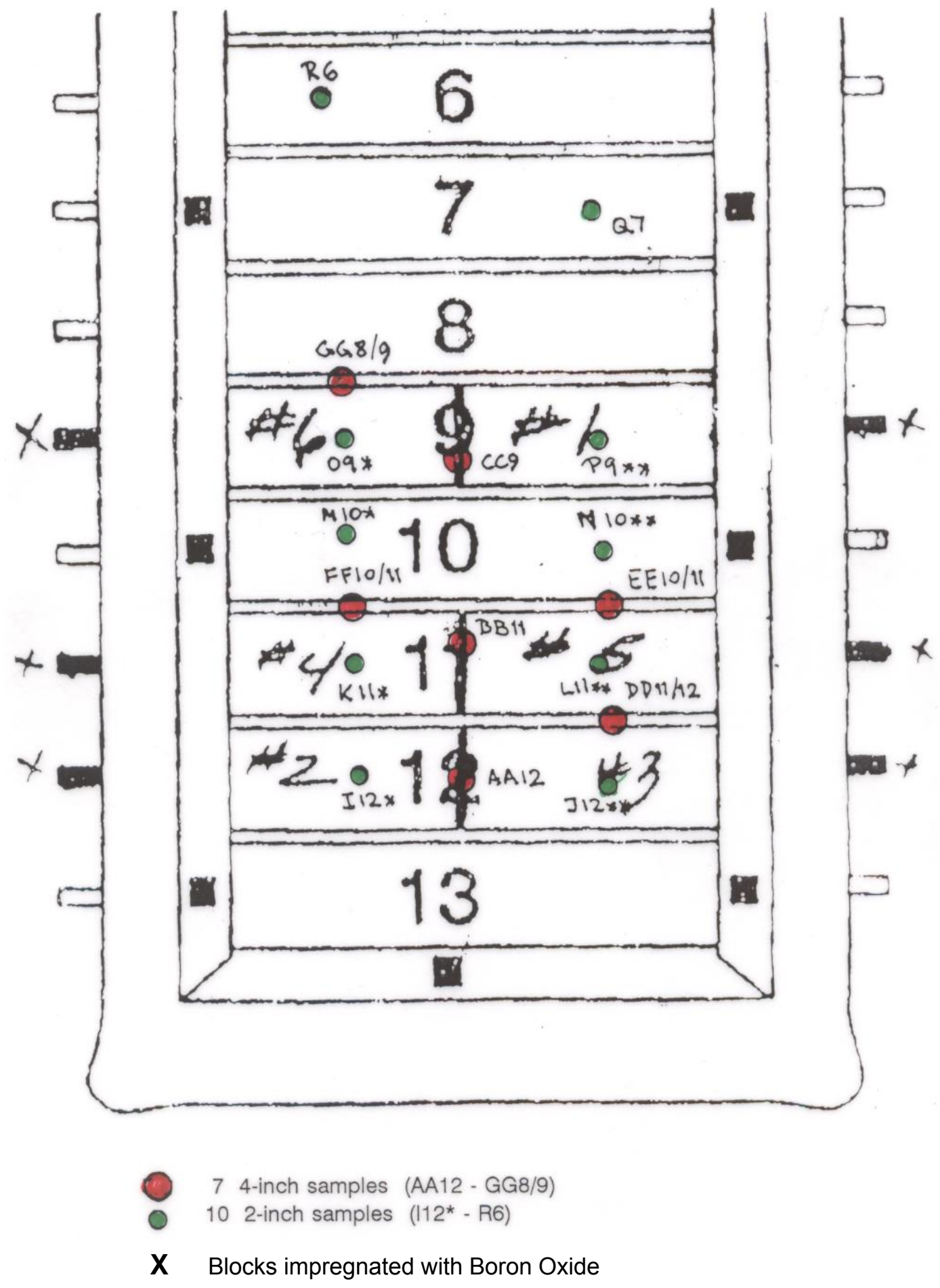




\section{PHASE III FULL CELL TEST}

\section{Preparation of Blocks}

Twenty-six half-length amorphous cathode blocks containing $30 \%$ graphite were supplied by SGL Carbon. They were of the same quality as blocks procured by Century Aluminum at the same time. The half-length blocks were $1.086 \mathrm{~m}$ (42.75 in) long, $0.394 \mathrm{~m}$ wide and $0.356 \mathrm{~m}$ high. The combined length of two blocks was $0.0635 \mathrm{~m}$ (2.5 in) shorter than the length of the blocks normally used in the Ravenswood smelter, to accommodate a center seam to connect the two halves placed on a collector bar. Figure 13 shows the impregnated blocks placed in the pot prior to the seams being sealed with ramming paste.

Figure 13: Impregnated blocks in the pot prior to ramming paste being added.

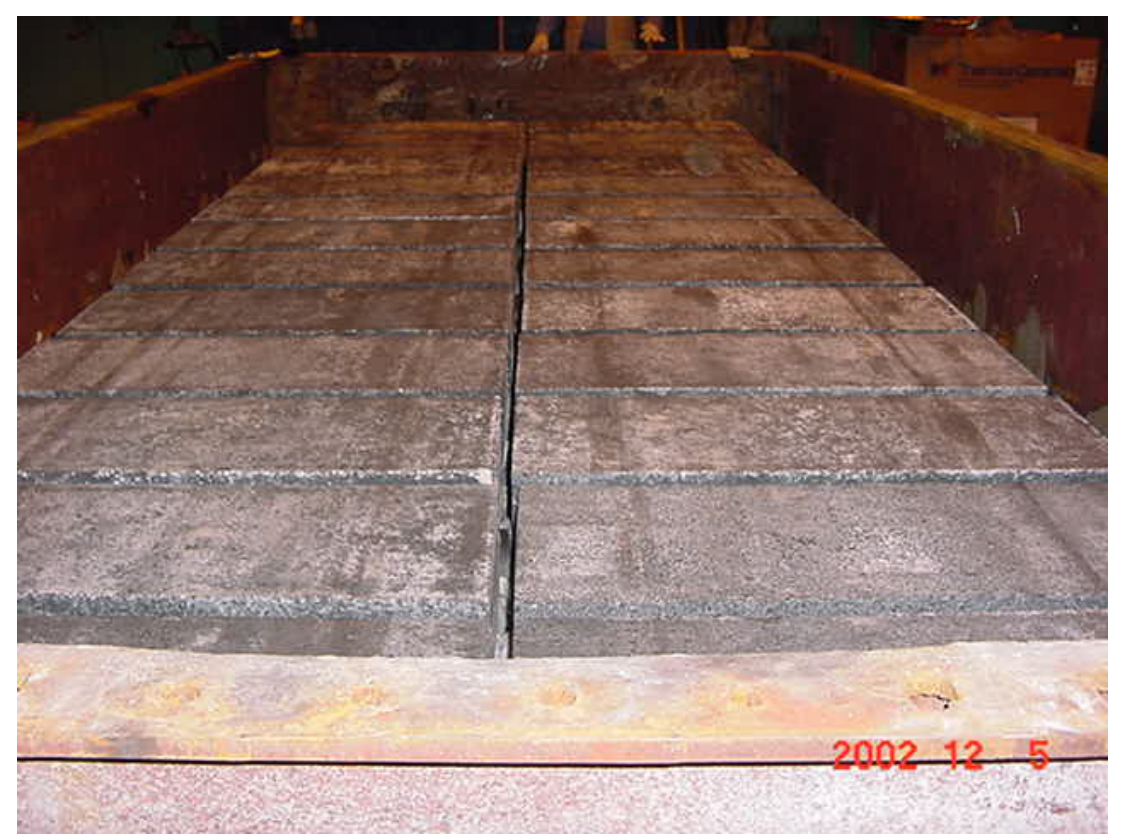

The blocks were impregnated in EMEC Consultants' Warren Haupin Pilot Facility using the procedure established in Phase II of the program: impregnation with a boron oxide melt containing nominally $3 \mathrm{wt} \%$ borax in two steps of 9 hours impregnation under pressure each, interrupted by an overnight rest period. Weight gains of the blocks were determined after cleaning of the block surfaces and are listed in Table 4. 
Table 4: Weight gains of individual blocks used for the test cell.

Duct End

\begin{tabular}{|l|}
\hline $11.80 \%$ \\
\hline $12.56 \%$ \\
\hline $13.14 \%$ \\
\hline $13.39 \%$ \\
\hline $13.62 \%$ \\
\hline $13.74 \%$ \\
\hline $13.90 \%$ \\
\hline $13.96 \%$ \\
\hline $13.42 \%$ \\
\hline $13.17 \%$ \\
\hline $13.00 \%$ \\
\hline $12.44 \%$ \\
\hline $11.34 \%$ \\
\hline
\end{tabular}

\begin{tabular}{|l|}
\hline $11.80 \%$ \\
\hline $12.52 \%$ \\
\hline $13.14 \%$ \\
\hline $13.19 \%$ \\
\hline $13.68 \%$ \\
\hline $13.56 \%$ \\
\hline $14.70 \%$ \\
\hline $13.96 \%$ \\
\hline $13.45 \%$ \\
\hline $13.17 \%$ \\
\hline $13.11 \%$ \\
\hline $12.72 \%$ \\
\hline $11.36 \%$ \\
\hline
\end{tabular}

Weights of Impregnation given as \% weight gain of blocks by impregnating boron oxide melt. Blocks are slightly less dense than the boron oxide melt.

The impregnated blocks were cleaned with a de-scaling tool ("needle gun"), except for the collector bar slot which was scraped upon withdrawal of the block from the hot melt in the pressure vessel.

At Precision Inc. in Sistersville, West Virginia, collector bars were mounted into the collector bar slots with cast iron. One full-length collector bar was placed into two halflength blocks. The arrays were delivered to Ravenswood for placement into a shell to be relined.

\section{Cell Start-up}

The cell was ready for start-up on 12 December 2002. It was placed in Potline \# 2 of the Century Aluminum of West Virginia smelter in Ravenswood and had the designation 2A39. The blocks were mounted on collector bars in Sistersville, WV, and the blocks were then placed in the cell and the seams rammed by Century Aluminum personnel. There was a center seam in the cell since the impregnated blocks were half-length blocks. The seam mix did not contain any boron oxide. 2A50 was a comparison pot 
that was started 32 days later with standard nonimpregnated blocks and without a center seam.

A routine gas bake that lasted 48 hours was started on 12 December 2002 at 10:30 a.m. Bath was added on 14 December 2002, from 10:45 a.m. to 11:00 a.m., metal the same day at 6:00 p.m. The pot was thus started on 14 December 2002. Bath was first added to the pot with some titanium placed on the surface of the cathode blocks to initiate the formation of titanium diboride. Aluminum containing $0.05 \mathrm{wt} \%$ titanium was then added 8 hours later. The initial voltage on the pot was 8 volts, but was brought under 8 volts before the aluminum was added to the pot.

Century Aluminum personnel noted that voltage had to be added to the cell initially because the pot was not "taking off voltage." "Temp Voltage" had to be added on the second day because the pot was listed as running cold $\left(940-949^{\circ} \mathrm{C}\right)$. The pot stabilized with a base voltage of $4.45 \mathrm{~V}$ on the fifth day of operation. The initial Ti level in the metal pool was maintained at $0.05 \mathrm{wt} \%$.

\section{Cell Operation}

The cell was operated at the $93 \mathrm{kA}$ of Potline \# 2 from 14 December 2002 to 12 November 2003. Century Aluminum personnel ran the cell as a normal pot, except for the titanium that was added to the aluminum to enable the formation of $\mathrm{TiB}_{2}$. The normal operating data was collected for this pot; this includes: base voltage, operating voltage, noise data, time on temporary voltage, bath temperature, etc. The topography on this pot was measured more often than normal, and cathode voltage drop data also was taken periodically.

The pot did not behave as expected. The noise and voltage levels were higher than normal and, compared to the control pot, cathode voltage drops were also greater. There was some sludge and deposit formation on the cathode blocks, and there were indications suggesting excessive heat loss through the bottom. The production rate was also lower than expected. These aspects of the test are discussed in detail below; they were published by Century Aluminum authors ${ }^{16}$.

16 M. McClung, J. Browning, S. Carte, C. Lightle, R. O. Love, and R. Zerkle, "Plant Experience with an Experimental Titanium Diboride Cell”, Light Metals 2004, pp. $399-404$, (2004). 


\section{$\underline{\text { Titanium Additions }}$}

Whenever metal was removed from the pot, a quantity of an aluminum alloy containing $10 \mathrm{wt} \%$ titanium was added to maintain the desired titanium content in the metal pool. During the first six months, the targeted value was $0.05 \mathrm{wt} \%$ titanium. This was temporarily reduced to $0.025 \mathrm{wt} \%$ for the period 17 June 2003 to 23 September 2003. The titanium level was increased again to 0.05 -wt $\%$ because it was difficult to maintain the level at $0.025 \%$ and, since the pot was not operating well it was determined that the $0.05 \%$ level would possibly yield better results. The titanium content was periodically determined by quantometer analysis and amounts added adjusted if necessary.

\section{$\underline{\text { Noise and Voltage Behavior }}$}

As illustrated in Figure 14, the noise level in pot 2A39, which contained the impregnated blocks, as compared to pot 2A50 (normal pot in the same tapping group started at nearly the same time, 32 days later), was higher. Exceptions to this trend were observed during the very beginning and also during a period from days 225 to 266 . In the latter case, efforts to achieve a quiet pot operation were successful, but this was interrupted, evidently as some problems occurred in the entire potline. Pot $2 \mathrm{~A} 39$ had an average voltage of $4.59 \mathrm{~V}$, as compared to $2 \mathrm{~A} 50$ 's average of $4.47 \mathrm{~V}$, or 0.12 volts higher. Pot 2A39, furthermore, had an average noise level of 0.038 , compared to 0.028 for $2 \mathrm{~A} 50$, or 0.01 more noise. Figure 14 and the calculated averages show that the experimental pot was running at a higher voltage and noise throughout most of the testing period. The reasons for this will be discussed later.

\section{Cathode Voltage Drop Measurements}

The cathode voltage drops (CVDs) for the two pots were taken periodically by Century Aluminum personnel. This was done by lowering a probe to the bottom of the pot to touch the block or hard solid material, then raising it up by 1 inch $(2.5 \mathrm{~cm})$. The voltage drop was recorded to the bar on the outside of the pot. Data was collected for each cathode block periodically for both pots $2 \mathrm{~A} 39$ and 2A50.

The resulting CVDs were, on average, higher for the test pot 2A39 than for the reference pot. These averages are shown in Table 5, and there are several potential reasons for this difference. An increase in block resistivity occurred according to data collected during the partial evaluation of autopsied material (see p. 60), but it could have contributed only partially to the higher values. A possible explanation is the formation of sludge or muck on the bottom of the pot; the associated deviation from uniform current density distribution inherently leads to a higher ohmic drop. There indeed were periods of time during the test that there was thought to be some formation of sludge and 
deposits in the experimental pot, but during the very last two observations, there was thought to be little sludge or muck present. The difference could have been due to the test pot (2A39) having a "cold bottom" (lower temperature at the carbon block/aluminum interface). As CVD values were temporarily lower, a problem of the contact area between collector bar and cathode block was ruled out.

Figure 14: Operating voltage and noise observations.
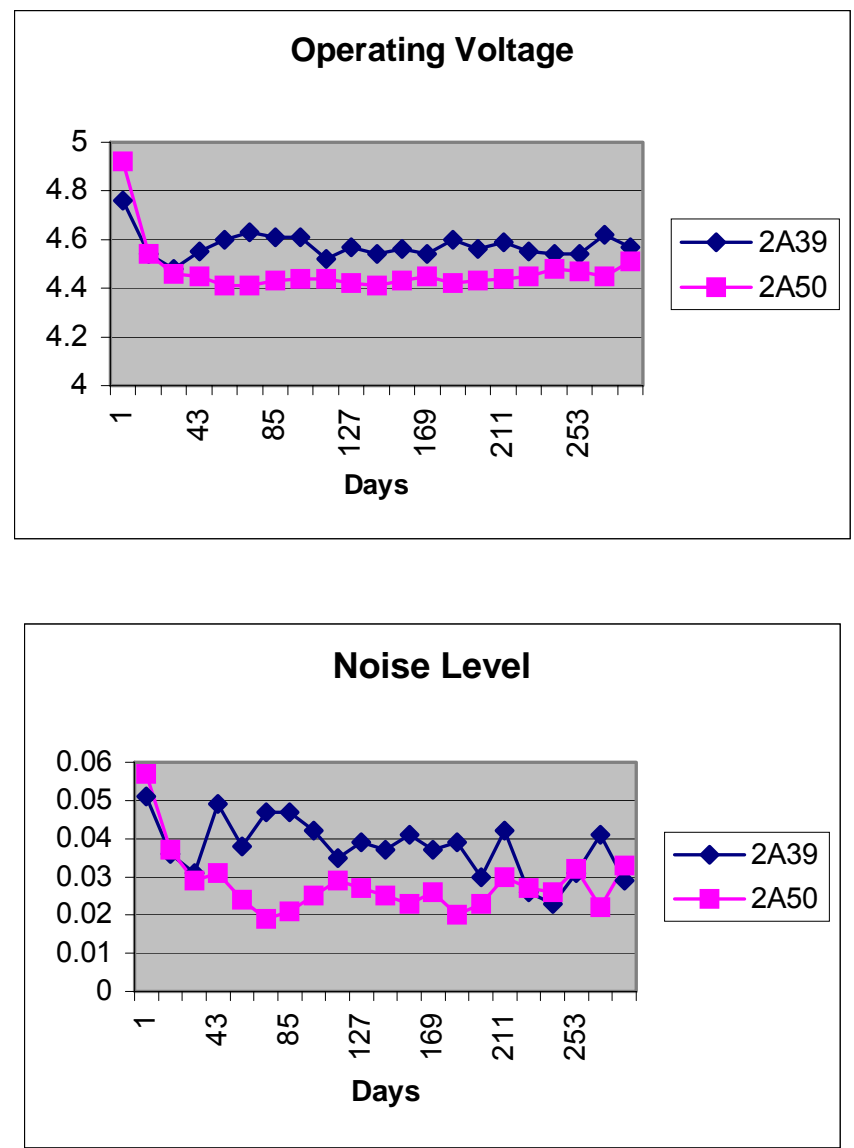
Table 5: Average cathode voltage drops for 2A39 and 2A50.

\begin{tabular}{|lc|l|lc|l|}
\hline Date & $\begin{array}{c}\text { Age } \\
\text { (days) }\end{array}$ & $\begin{array}{l}\text { Test Pot 2A39 } \\
(\mathbf{m V})\end{array}$ & Date & $\begin{array}{c}\text { Age } \\
\text { (days) }\end{array}$ & $\begin{array}{l}\text { Reference Pot } \\
\text { 2A50 (mV) }\end{array}$ \\
\hline $1 / 11 / 2003$ & 28 & 365.577 & $2 / 11 / 2003$ & 27 & 381.0 \\
$3 / 13 / 2003$ & 89 & 553.077 & & & \\
$6 / 11 / 2003$ & 179 & 430.52 & $5 / 23 / 2003$ & 128 & 324.4 \\
$7 / 18 / 2003$ & 216 & 452.46 & $7 / 16 / 2003$ & 182 & 315.0 \\
$7 / 25 / 2003$ & 223 & 344.69 & & & \\
$9 / 9 / 2003$ & 269 & 464.81 & $11 / 17 / 2003$ & 304 & 311.35 \\
$11 / 17 / 2003$ & 348 & 457.88 & * & & \\
\hline \multicolumn{5}{|c|}{ * Data from Century Aluminum of West Virginia } \\
\hline
\end{tabular}

\section{Formation of Sludge and/or Hard Muck on Cathode Blocks}

There were some sludge and hard muck (deposits) on the cathode blocks. Such lowconductive accumulations generally lead to instabilities (noise) in pot operation, as they increase horizontal current components in the aluminum. When there was an alumina feeding problem in the entire line at one point during the test, it was observed that the resulting problem was exacerbated in the test pot. The pot was thought to have a "cold bottom", i.e. the heat loss through the cell bottom (typically $10-15 \%$ of the total heat loss) was enhanced (resulting in increased temperatures at lower parts of the shell).

Several actions were taken by Century Aluminum of West Virginia to reduce or eliminate the formation of sludge and hard muck in this pot. The metal pad was lowered in order to decrease heat loss through the sidewalls. The voltage was increased to produce more heat in the pot that would eliminate and prevent the formation of these accumulations, thus reducing noise. The bath ratio was also changed from 1.12 to 1.14 in an attempt to solve the problem. These efforts appeared to reduce the formation of these accumulations, at least temporarily. There was some sludge and possibly hard muck found during the autopsy, as will be discussed later. Feeding of alumina (pure ore) was controlled by normal cell control. Some feeding problems were reported on occasion for the entire potline, and there was also a need to repair one of the feeders.

\section{"Cold Bottom Pot"}

The observations during the test have indicated that this pot seemed to be a "cold bottom pot" (all pots in the line actually tend to run with cold end bottoms). The 
formation of accumulations containing undissoved alumina on the cathode surface, higher cell voltage, lower bath temperatures, increased voltage drop through the cathode, increased noise, and overall instability in the pot are all indications that are consistent with the fact that the bottom of the pot lost more heat than normal. A pot with a "cold bottom" (referring to the bottom of the liquid phases in the cell) appears be the most logical explanation for these observations.

The presence of boron oxide in the blocks was considered to be one reason that this pot had a "cold bottom". Cathode blocks impregnated with boron oxide may increase the heat conductivity of the blocks since the boron oxide is being placed in many of the pores in the block. This condition, however, existed from the very beginning, while a smooth operation was observed initially; normal bath penetration should also have similar effects. Another explanation for the "cold bottom" could be the boron oxide leaching into the refractories under the cathode blocks. Samples of this material taken in the autopsy indeed indicated a boron oxide content in the upper refractory layer (results shown in the autopsy discussion). This leaching, however, did not appear to have caused a substantial increase in the heat conductivity of the refractories, according to heat conductance measurements on autopsied and virgin materials. A third factor could be that wetting of the cathode block by aluminum enhanced the heat transfer coefficient between aluminum and carbon. It was found that additional thermal insulation was needed in early testing of titanium boride coatings by Boxall ${ }^{17}$.

\section{Measurement of Shell Temperatures}

The heat loss in the lower part of the cell, of course, occurs through the shell of the pot. Shell temperatures measured on low parts of the pot on 17 November 2003 indicated that pot $2 \mathrm{~A} 39$ (test pot) had an average sidewall temperature of $250{ }^{\circ} \mathrm{C}$ and the reference pot had an average sidewall temperature of $230{ }^{\circ} \mathrm{C}$. The measurement of a 20-degree difference was considered not statistically significant, but it would imply the enhanced heat loss through the bottom.

\section{Production Rate (Current Efficiency)}

The production rate for this pot was about $2 \%$ lower than for the average pot in the line. It was determined by weighing the tapped metal. While new pots normally are easy to tap, this pot was difficult to tap due to the low metal pad and buildup of material on the

carbon. A special effort was made by Century Aluminum of West Virginia personnel to accurately determine the production rate of this pot.

17 L. Boxall, Private Communication (2004). 


\section{Pot Shutdown and Autopsy}

\section{Termination of Operation and Removal of Cell}

The pot was shutdown on 18 November 2004 with a modified shutdown procedure after the final measurements were taken on 17 November 2004. In order to maintain any titanium diboride that was present at the end of the test, one inch $(2.5 \mathrm{~cm})$ in depth of aluminum was to be left in the pot after shutdown. Otherwise, the $\mathrm{TiB}_{2}$ may have been removed with the aluminum layer precluding its detection during the autopsy, since the $\mathrm{TiB}_{2}$ produced during this process is found in the aluminum layer adjacent to the carbon surface. The metal was tapped from the cell until it was determined that the targeted depth of aluminum remained in the pot. The power was then removed from the pot and the bath was siphoned off. The pot remained in place until it had cooled.

The pot was removed from the pot room on 24 November 2004 and taken to a separate building where it was stored and protected until the autopsy. The deck plate and sidewall were removed in this building prior to the autopsy, but any remaining bath and the aluminum in the pot were left in place to preserve the carbon surface and prevent absorption of water by the blocks. Plastic sheeting protected the cell until EMEC Consultants and SGL Carbon personnel arrived for the scheduled autopsy, 8 December 2004.

\section{Appearance of the Shutdown Pot}

General observations were taken regarding the shell condition, strap condition, sidewall configuration, etc. once the cell was shutdown. The bars and superstructure appeared to be in good shape, but the straps appeared slightly oxidized, indicating the possibility that excess heat was lost through the bar/strap connection, Figure 15. The sidewalls and deck plate were removed from the pot once it was moved to the separate building, and pictures of the resulting pot were taken and shown in Figure 16.

The autopsy was conducted from 9 December 2004 thru 11 December 2004. The metal pad remaining was removed at that time and the carbon surface was revealed. Figure 16 shows the appearance of the pot bottom after pulling the solidified remainder of the metal pad. The blocks did not appear to have heaved during the one-year test, but there seemed to be some deposits on the blocks as muck or sludge. There was also aluminum that remained attached to the carbon surface, which could be indicative of the aluminum wetting the carbon surface. There was no tapping hole present in the carbon, and the tapping area was especially clean of any deposits. 
Figure 15: Bars and connections.
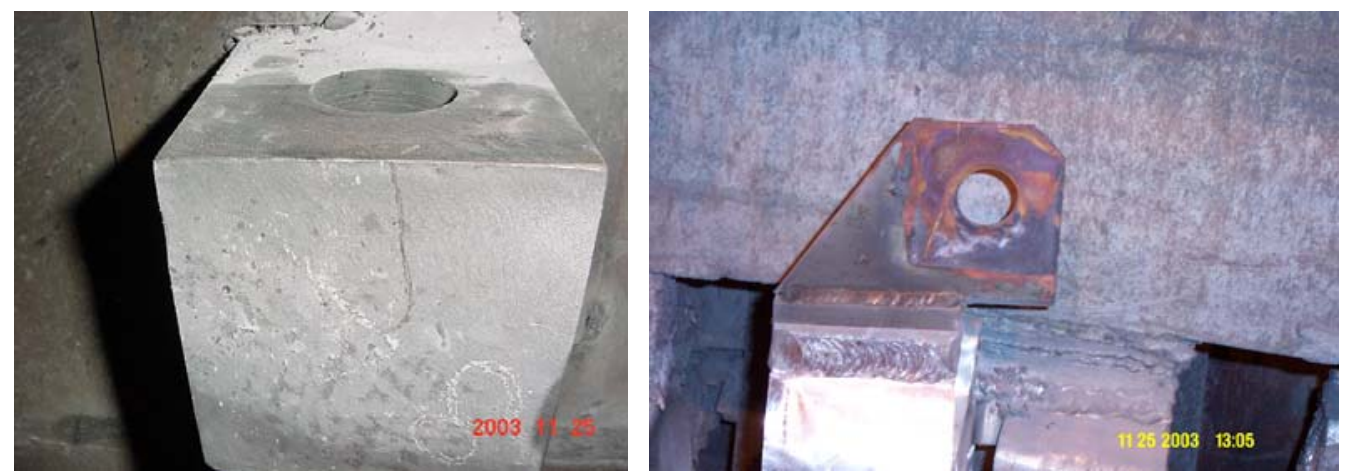

Overall, the cell appeared to be in good shape. There was some pitting on the carbon surface, which is normal, especially when deposits have been present. The remaining debris was removed for the core drilling, but the pot was not rolled over until the core drilling was completed.

Figure 16: The pot before and after the metal pad was removed.

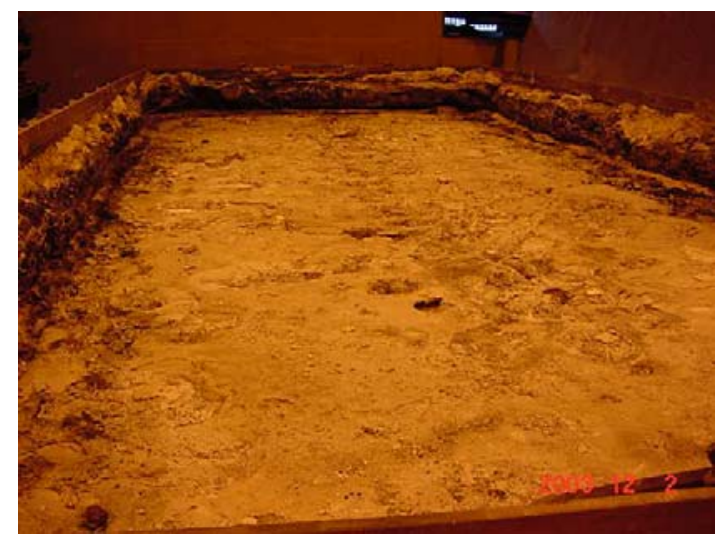

before aluminum was removed

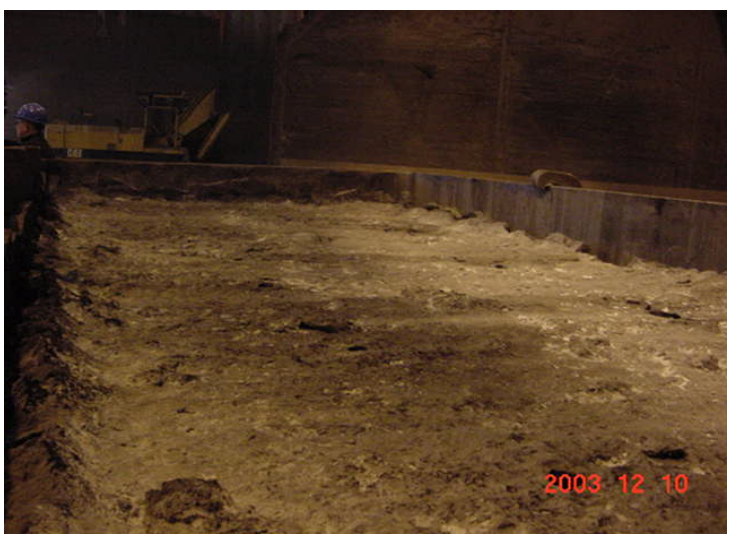

after aluminum was removed

\section{Sampling of Carbon Block Material}

The sampling of the carbon block material was accomplished by core drilling the carbon material at different locations in the pot. This was completed during the autopsy by Century Aluminum of West Virginia personnel using a special rig engineered to core-drill the carbon effectively and safely. Two inch $(5 \mathrm{~cm})$ and 4 inch $(10 \mathrm{~cm})$ diameter cores 
were taken from the pot, and the block material, as well as, the seam material was sampled. Each core was approximately 5-7 inches $(12.5-17.5 \mathrm{~cm})$ in depth. These samples would then be examined, analyzed, and tested later. The locations of the core samples are shown in Figure 17.

Attempts to core-drill through the metal pad, without use of the rig later installed, were not successful. Parts of the metal pad were cut off with an oxygen torch and collected. It is important to obtain a sample of the metal contacting the carbon surface in order to observe any $\mathrm{TiB}_{2}$ formation and wetting, thus obtaining the aluminum from the pot was thought to be critical. It was found during the autopsy, however, that some aluminum contacting the carbon remained in the pot after the main metal pad was removed (this was not observed in the Phase II test at Ravenswood). It seemed that this aluminum remained under some bath, sludge, or muck. There were, however, areas where the aluminum was contacting the carbon surface and no bath, sludge, or muck was found.

Indications that aluminum was produced below sludge or muck were obtained from an analysis of the metal found below this muck or sludge. Its titanium content was undetectable, well below that of the metal pool, and an SEM analysis of the sample did not show a significant formation of $\mathrm{TiB}_{2}$ that could have also removed the titanium from the aluminum. This indicates that this metal did not communicate with the metal pool. Some production of metal below sludge can be expected ${ }^{18 ;}$ while sludge generally has about half of the specific conductance of regular bath ${ }^{19}$, this conductivity is much lower than that of the aluminum metal, however.

18 R. Keller, "Alumina Dissolution and Sludge Formation Revisited", Manuscript in preparation for Light Metals 2005.

19 P-Y Geay, B. J. Welch, and P. Homsi, "Sludge in Operating Aluminum Smelting Cells", Light Metals 2001, pp. 541-547 (2001). 
Figure 17: Location of the core samples.

Duct End

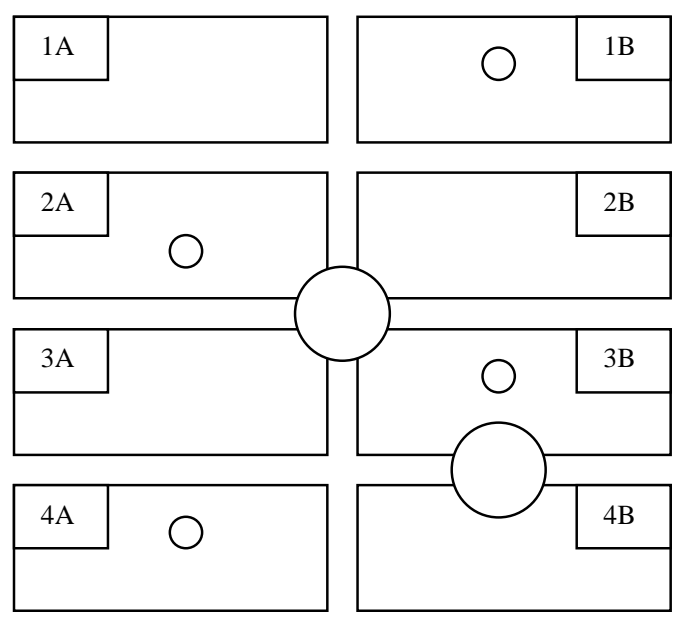

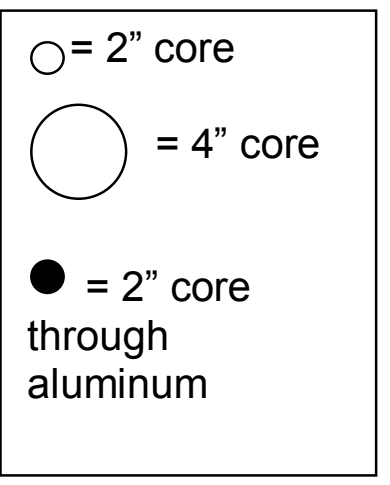
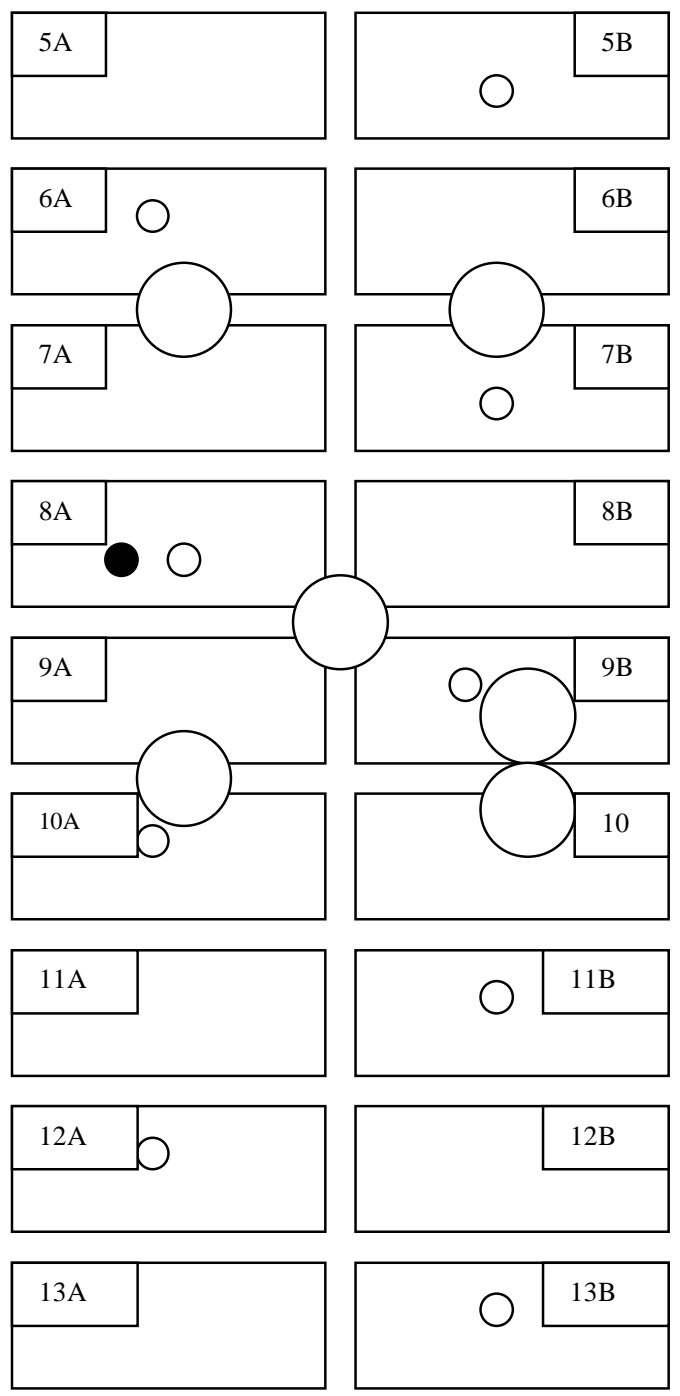
Core drilling of the carbon material was relatively easy, mainly due to the rig designed by Century Aluminum of West Virginia. The cores appeared to be in good shape, and many of the cores had metal adhering to the carbon at the top of the core, Figure 18. There was also consistently bath, sludge, or muck found on top of the metal on the core. The core samples, along with the block pieces, refractory samples, sidewall material, aluminum samples, and other miscellaneous samples, were taken to EMEC Consultants' laboratory for analysis.

Figure 18: Typical 2-inch diameter core sample (sectioned after recovery).

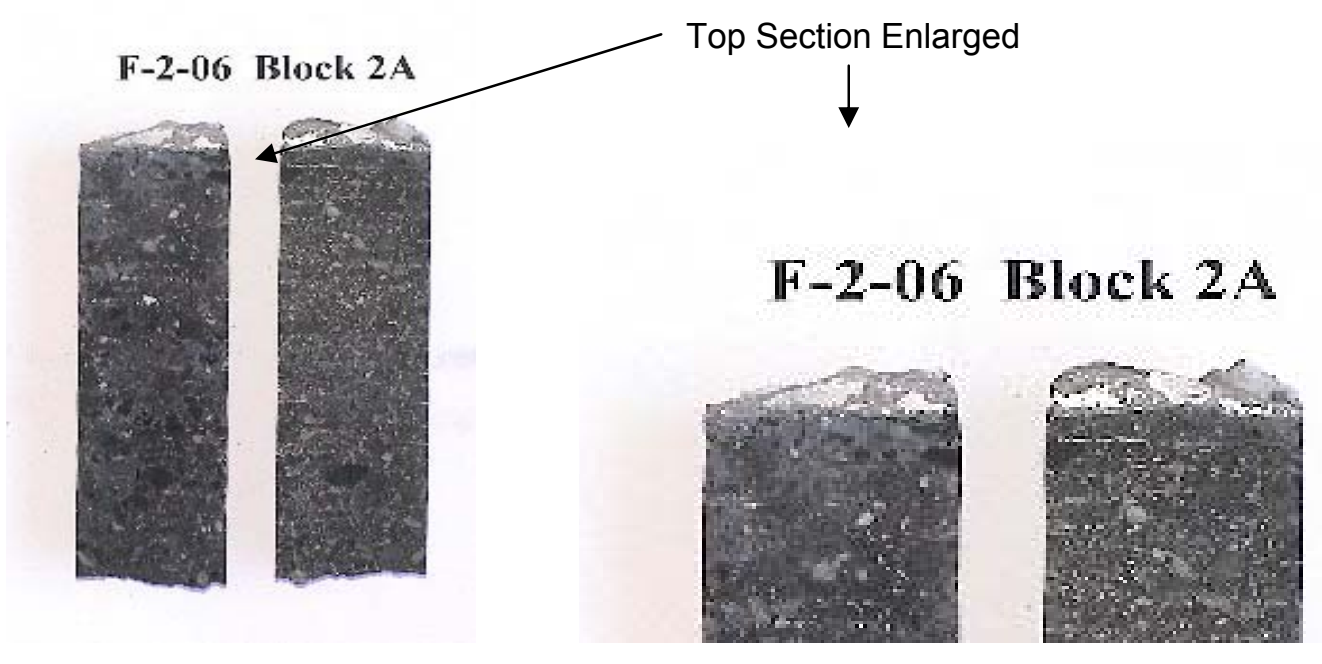

\section{Cathode Wear}

Four half-length blocks were removed from the pot during the autopsy in order to examine the cross section of the blocks, overall condition of the blocks, and to sample the refractories under the blocks. The blocks, once again, appeared to be in good shape. There was some normal pitting in the blocks, but the wear seemed to be minimal from a visual observation, as shown in Figure 19. A measurement of the block height indicated the same value as the initial block height. It was estimated that a wear rate greater than $6 \mathrm{~mm}$ ( 0.25 inch) would have been detected, which is considerably less than the value of $18 \mathrm{~mm}$ ( $0.75 \mathrm{inch})$ commonly encountered. No heaving of the blocks was noticed. 
Figure 19: Appearance of the cross section after removing 4 half-length blocks.

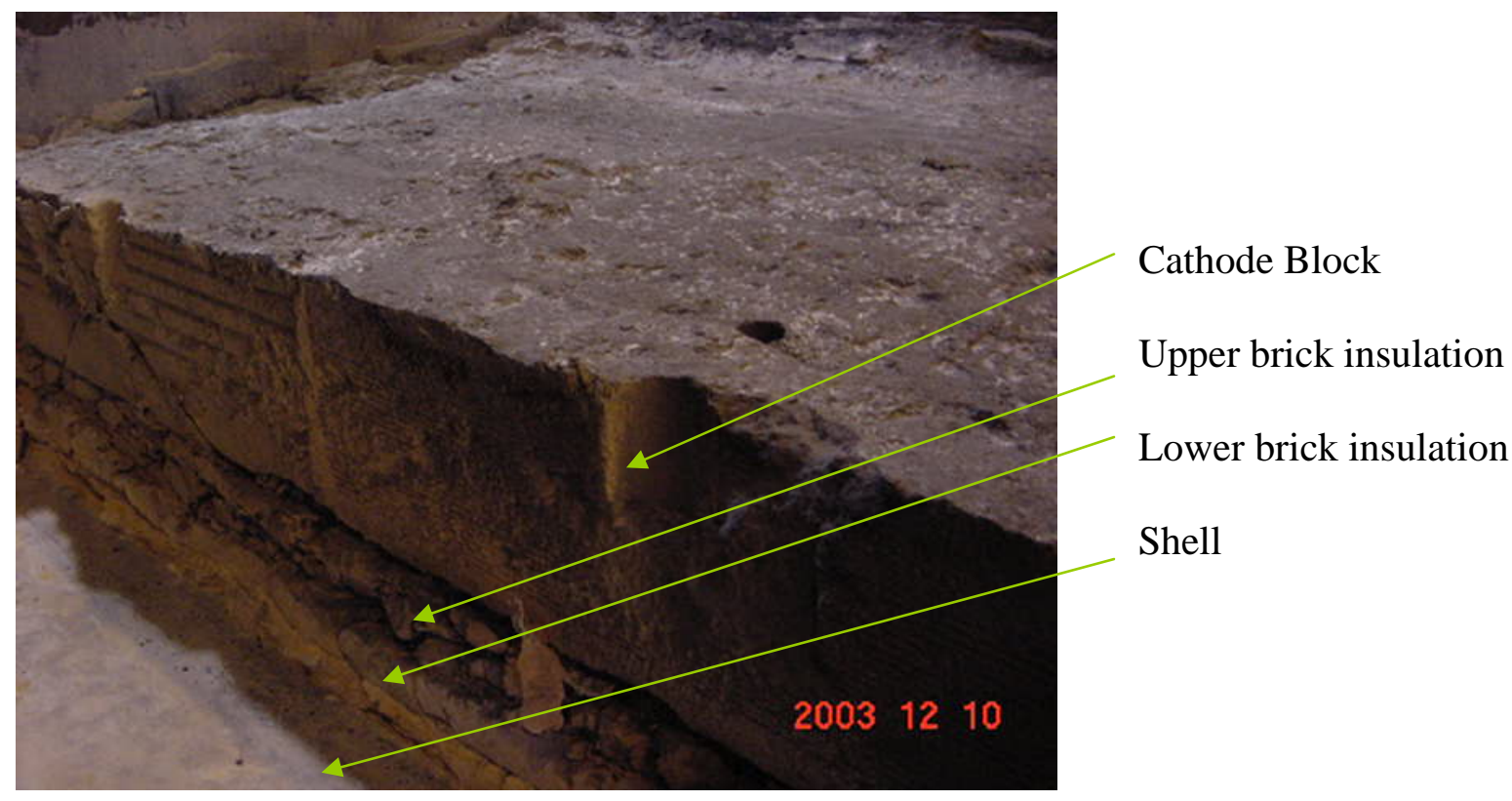

\section{Chemical Analysis of Boron Content}

The core samples taken during the autopsy at Century Aluminum of West Virginia were taken to EMEC Consultants' laboratory for examination and analysis. The amount of boron oxide remaining in these samples was of particular importance. The theory for the process is that boron oxide in the block will react with titanium added to the metal pool in the pot to form $\mathrm{TiB}_{2}$. In order for this reaction to continue, allowing the production of $\mathrm{TiB}_{2}$ for a significant period of time, the boron oxide in the block must last for the same amount of time. Several samples were selected and tested for boron oxide content.

The selected samples were sent to Galbraith Laboratories, Inc. located in Knoxville, TN. The samples were subsequently ground and digested with a carbonate. The resulting material was then analyzed using an ICP detection to determine the amount of boron contained in the sample, which was then reported to EMEC Consultants. The amount of boron oxide in the sample was simply extrapolated from the reported boron content by multiplying the value by 3.23 (without any consideration being given to the presence of some borax or boron-containing reaction products). 
The samples were chosen in order to analyze different locations in the pot and to determine the vertical distribution of boron oxide in the blocks. The vertical distribution was determined with the samples taken from Block 10A that was removed from the pot during the autopsy. Samples of the refractory material under the blocks were also taken to analyze this material for boron oxide. The selected samples that were analyzed for boron content and the resulting boron values are given in Table 6.

There is a significant amount of boron oxide remaining in the blocks after this one-year test. About one-half of the original boron oxide in the blocks is still present and available to continue to produce $\mathrm{TiB}_{2}$. The average remaining boron oxide in the top 5 inches $(12.5 \mathrm{~cm})$ of the blocks is $6.71 \%$. There seems to be more boron oxide remaining in the top 1 inch $(2.5 \mathrm{~cm})$ of the block $(7.02 \%)$ as compared to the lower $5-6$ inches $(12.5-15 \mathrm{~cm})$ of the block $(6.39 \%)$, but this difference may not be statistically significant. The average amount of boron oxide remaining in the core-drilled samples and the standard deviation are presented in Table 7.

In addition, there is an indication that there was less boron oxide remaining toward the bottom of the block. The remaining boron oxide 4 inches $(10 \mathrm{~cm})$ above the collector bar slot was $5.04 \%$, while the boron oxide remaining directly on top of the collector bar slot was $3.26 \%$. This difference is also reflected in the bottom of the block in general where 5 inches $(12.5 \mathrm{~cm})$ up from the bottom the average boron oxide remaining was $4.94 \%$ and at the bottom there was $2.78 \%$ remaining. The relative locations of these resulting boron oxide data are represented in Figure 20, along with some values for layers (glass and refractories) below the cathode blocks. 
Table 6: Analysis for boron oxide and sodium (in wt\%).

\begin{tabular}{|c|c|c|c|c|}
\hline Sample ID & Sample Location & $\begin{array}{l}\text { Original } \\
\mathrm{B}_{2} \mathrm{O}_{3}\end{array}$ & $\begin{array}{l}\text { Remaining } \\
\mathrm{B}_{2} \mathrm{O}_{3}\end{array}$ & Sodium \\
\hline F-2-02 Top & Block 10A Top & 13.17 & 8.91 & 12.1 \\
\hline F-2-02 Bottom & Block 10A 5" Down & 13.17 & 6.75 & 10.67 \\
\hline F-2-05 Top & Block 4A Top & 13.39 & 7.17 & 13.08 \\
\hline F-2-05 Bottom & Block 4A 5" Down & 13.39 & 6.88 & 11.80 \\
\hline F-C-2 Upper & $\begin{array}{l}\text { Block 10A 5" up from } \\
\text { bottom of block }\end{array}$ & 13.17 & 4.94 & 10.99 \\
\hline F-C-2 Lower & $\begin{array}{l}\text { Block 10A bottom of } \\
\text { block }\end{array}$ & 13.17 & 2.78 & 11.69 \\
\hline F-C-10 & Center Seam & - & 4.36 & 19.91 \\
\hline F-C-11 & Seam & - & 4.91 & 17.82 \\
\hline F-C-12 Upper & $\begin{array}{l}\text { Block } 104 \text { " up from } \\
\text { collector bar slot }\end{array}$ & 13.17 & 5.04 & 9.36 \\
\hline F-C-12 Lower & $\begin{array}{l}\text { Block } 10 \text { over the } \\
\text { collector slot }\end{array}$ & 13.17 & 3.26 & 9.91 \\
\hline F-2-09 Upper & Block 5B Top & 13.68 & 5.23 & N/A \\
\hline F-2-09 Lower & Block 5B 5" Down & 13.68 & 5.43 & N/A \\
\hline F-2-04 Upper & Block 6A Top & 13.74 & 5.81 & $\mathrm{~N} / \mathrm{A}$ \\
\hline F-2-04 Lower & Block 6A 5" Down & 13.74 & 6.95 & N/A \\
\hline F-2-13 Upper & Block 13B Top & 11.36 & 7.98 & N/A \\
\hline F-2-13 Lower & Block 13B 5" Down & 11.36 & 7.85 & N/A \\
\hline F-2-10 Upper & Block 7B Top & 14.7 & 7.01 & N/A \\
\hline \multirow{5}{*}{ F-2-10 Lower } & Block 7B 5" Down & 14.7 & 4.49 & $\mathrm{~N} / \mathrm{A}$ \\
\hline & $\begin{array}{l}\text { Upper Brick - first under } \\
\text { block - top of brick }\end{array}$ & 0.00 & 3.65 & \\
\hline & $\begin{array}{l}\text { Upper Brick - first under } \\
\text { block - mid/bottom of } \\
\text { brick }\end{array}$ & 0.00 & 3.10 & \\
\hline & $\begin{array}{l}\text { Upper Brick - first under } \\
\text { block - bottom and glass }\end{array}$ & 0.00 & $<.25$ & \\
\hline & $\begin{array}{l}\text { Lower Brick - second } \\
\text { under block - top with } \\
\text { glass }\end{array}$ & 0.00 & $<.20$ & \\
\hline
\end{tabular}

Samples were analyzed for boron content and results presented as boron oxide. 
Table 7: Average boron oxide content remaining in the cathode blocks.

\begin{tabular}{|lll|}
\hline & Average & $\begin{array}{l}\text { Standard } \\
\text { Deviation }\end{array}$ \\
\hline All Cathodes & $6.71 \%$ & 1.62 \\
Top 1" & $7.02 \%$ & 1.36 \\
5" down & $6.39 \%$ & 1.27 \\
& & \\
Initial Average & $13.30 \%$ & 0.90 \\
\hline
\end{tabular}

Figure 20: Boron oxide analytical results in wt\%.

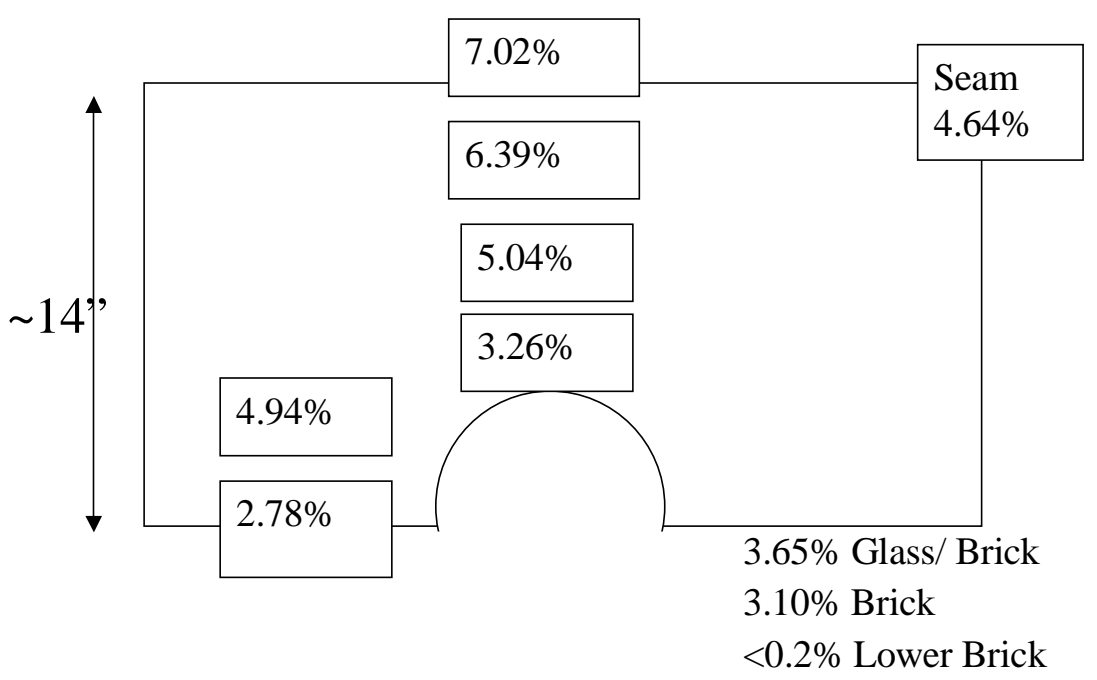


The boron oxide is present in the blocks at prevailing temperatures as a viscous melt. This melt evidently flowed to other parts of the pot. There was boron oxide found in the seams of the pot and in the first layer of refractories under the blocks. There was initially no boron oxide in the seams, but the analysis shows that they contained $4.64 \mathrm{wt} \%$ boron oxide, while the same is true for the refractories where there was 3.65$3.10 \mathrm{wt} \%$ boron oxide in the first layer of material (no significant amounts were found in the second layer of refractories). These movements, along with the use of boron oxide to form $\mathrm{TiB}_{2}$, explain boron oxide losses during the test. Based on laboratory experimentation, it was conjectured that there was a considerable amount of loss during the initial heating of the blocks, but this loss slowed over time. It is not know how much boron oxide was lost during the start-up of this pot (it may be significant that losses observed after 6 months in Phase II were of similar magnitude to that of the longer 11month test).

\section{$\underline{\text { Specific Electric Resistivity }}$}

The specific electric resistivity of impregnated and non-impregnated samples was measured for a comparison of any effect the impregnation may have on the cathode block material. Measurements were conducted at room temperature and at $600{ }^{\circ} \mathrm{C}$ on $10 \mathrm{~cm}$ long samples, core drilled from the Phase III test pot or cut from laboratory-type samples. The results and the test set-ups are presented in Table 8.

The specific resistivity measurements of the impregnated samples that were not used in any testing were higher than that measured for the virgin material (values for the virgin material are, however, about half of values quoted by Sorlie and $\mathrm{Oye}^{20}$ for amorphous material with $30 \%$ graphite in the course fraction). At this point, it is not clear if, and in what way, boron oxide would effect the resistivity, or if an effect of exposure during impregnation causes a change. Remarkably, there seems to be no increase in graphitized material.

\section{Chemical Changes in the Cathode Blocks}

Aluminum in the metal pool always contains some sodium at low activity. Sodium penetrates into the cathode block and intercalates into the carbon. This process occurs to a larger extent in the amorphous-type cathodes as compared to the graphitized-type blocks. According to thermodynamic equilibrium calculations, the following reaction may be expected to occur:

$$
8 \mathrm{~B}_{2} \mathrm{O}_{3}+\mathrm{C}+12 \mathrm{Na} \rightarrow 12 \mathrm{NaBO}_{2}+\mathrm{B}_{4} \mathrm{C}
$$

20 M. Sorlie and H. A. Oye, "Cathodes in Aluminum Electrolysis", $2^{\text {nd }}$ edition, Aluminium-Verlag (1994). 
Table 8: Electrical resistivity data from laboratory testing at 30 amps.

\begin{tabular}{|c|c|c|c|c|c|}
\hline Sample Type & Temperature & \multicolumn{4}{|c|}{ Calculated Resistivity $(\Omega \mathrm{cm})$} \\
\hline $\begin{array}{c}\text { graphitized } \\
\text { not impregnated }\end{array}$ & Room & $.0015^{1}$ & \multicolumn{2}{|c|}{$.0013^{2}$} & $.0011^{4}$ \\
\hline $\begin{array}{c}\text { graphitized } \\
\text { not impregnated }\end{array}$ & 600 & $.0015^{2}$ & \multicolumn{2}{|c|}{$.0009^{4}$} & \\
\hline $\begin{array}{c}\text { graphitized } \\
\text { impregnated }\end{array}$ & Room & $.0018^{1}$ & \multicolumn{2}{|c|}{$.0015^{2}$} & $.0014^{4}$ \\
\hline $\begin{array}{l}\text { graphitized } \\
\text { impregnated }\end{array}$ & 600 & $.0011^{2}$ & \multicolumn{2}{|c|}{$.00067^{4}$} & \\
\hline $\begin{array}{l}\text { amorphous 30\% } \\
\text { graphite not } \\
\text { impregnated }\end{array}$ & Room & $.0020^{1}$ & \multicolumn{2}{|c|}{$.0021^{2}$} & \\
\hline $\begin{array}{c}\text { amorphous } 30 \% \\
\text { graphite not } \\
\text { impregnated }\end{array}$ & 600 & $.0015^{2}$ & & & \\
\hline $\begin{array}{c}\text { amorphous } 30 \% \\
\text { graphite impregnated }\end{array}$ & Room & $.0038^{1}$ & \multicolumn{2}{|c|}{$.0028^{2}$} & \\
\hline $\begin{array}{c}\text { amorphous } 30 \% \\
\text { graphite impregnated }\end{array}$ & 600 & $.0032^{2}$ & & & \\
\hline $\begin{array}{c}\text { amorphous 30\% } \\
\text { graphite impregnated } \\
\text { run at Century } \\
\text { Aluminum }\end{array}$ & Room & $.0046^{1}$ & $.0041^{1}$ & $.0061^{3}$ & $.0076^{3}$ \\
\hline $\begin{array}{c}\text { amorphous } 30 \% \\
\text { graphite impregnated } \\
\text { run at Century } \\
\text { Aluminum } \\
\end{array}$ & 600 & $.0039^{3}$ & $.0054^{3}$ & & \\
\hline
\end{tabular}

**The superscript number refers to the testing set-up below.

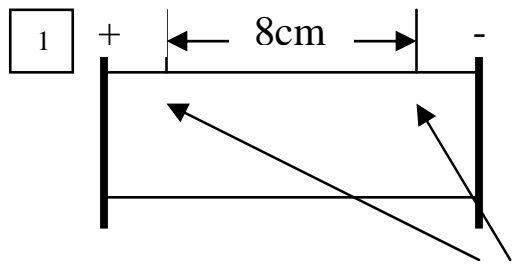

$\mathrm{mV}$ drop measurement

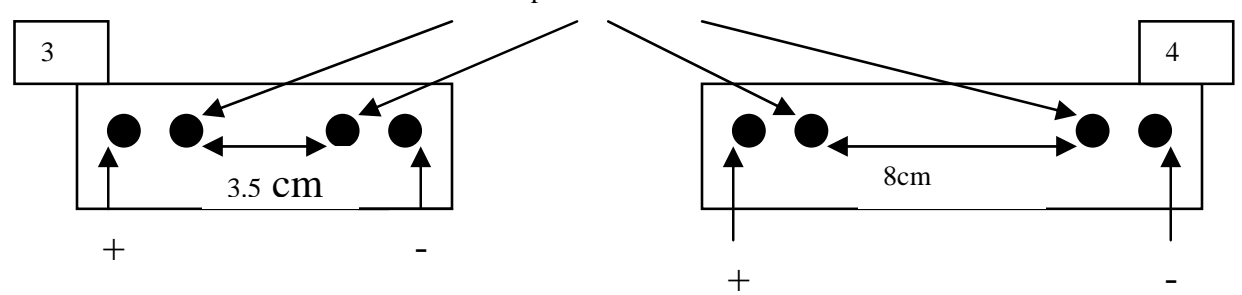


In the original proposal, we speculated that this reaction could suppress the sodium intercalation. However, we observed the presence of sodium, evident from bubbling on cut sample surfaces and measurements of hydrogen evolution, in Phase I. In XRD studies on a Phase III sample, only traces of boron carbide, $\mathrm{B}_{4} \mathrm{C}$, were found. The intercalation of sodium seems to be thermodynamically favored (it was not considered when deriving above equation).

\section{SEM Analysis of Metal and Deposits}

Samples for SEM analysis were prepared from sectioned core samples, mainly carbon and adhering metal from the top of the core samples. These samples were analyzed with a scanning electron microscope, SEM, at RJ Lee Group, Inc., Monroeville, PA. The aluminum that was found on the core samples was analyzed for localized titanium accumulation. Any titanium accumulation would be indicative of $\mathrm{TiB}_{2}$ formation. The boron could not be detected with the available SEM equipment, and the titanium homogenously distributed in the metal was not of the concentrations that could be seen; only accumulations caused by the formation of $\mathrm{TiB}_{2}$ could be detected (see Phase I results). Any titanium, therefore, detected by the SEM is considered to most likely be in the form of $\mathrm{TiB}_{2}$. An example of an analysis result is shown in Figure 21.

The results indicate that there were locations of $\mathrm{Ti}$ accumulation found in this sample. There were also several other samples that contained similar $\mathrm{Ti}$ accumulation, therefore, it seems that there was $\mathrm{TiB}_{2}$ and probably wetting of the carbon present at shutdown of this one-year test.

There was a considerable amount of other deposited material on the carbon surface. There were problems with ledging and sludge and muck formation during the testing of this pot. Samples of this deposited material were taken in order to determine if muck might have remained on the bottom of the pot. If significant amounts of muck or sludge covered the carbon surface in the pot, this muck or sludge would prevent the boron oxide in the block from reacting with the titanium in the aluminum pad to form $\mathrm{TiB}_{2}$ to promote wetting. The material collected from the pot was analyzed to determine if this was muck, sludge, or simply bath. The results are shown in Figure 22.

The analysis of the non-metal material found on the carbon surface throughout the pot indicated that much of this material was bath. There was, however, some aluminum oxide material observed that might have been hard muck. The aluminum oxide was found as crystal pieces deposited on the carbon surface, and these crystals were also sent for XRD analysis at RJ Lee Group, Inc. It was found that some of these crystals were corundum, which could be indicative of a hard muck formation, however, there did 
not seem to be a significant amount of this material in the pot. No indications for the presence of any aluminum borides were obtained.

Figure 21: SEM analysis results.

\section{F-4: Block 12 A}
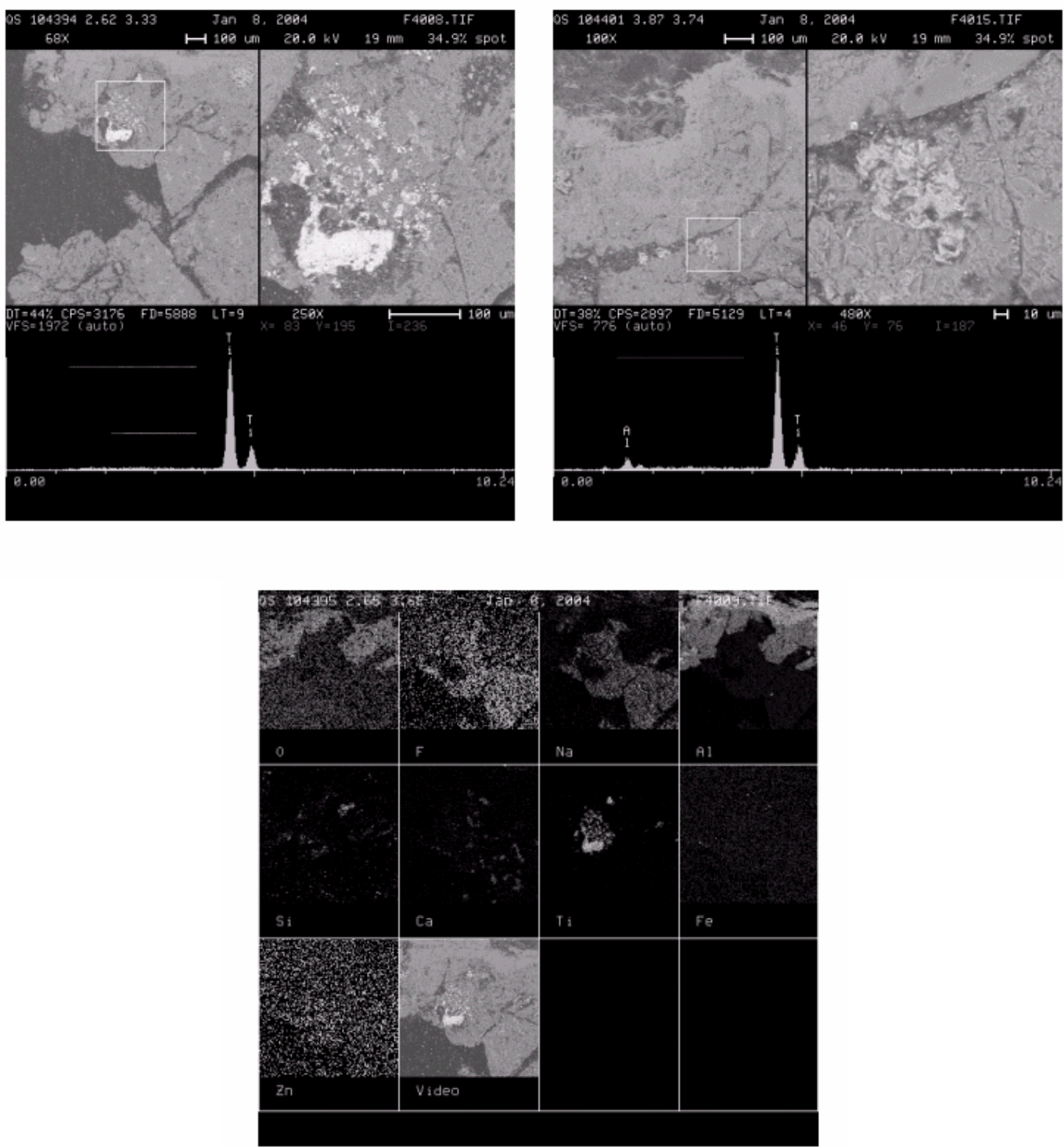
Figure 22: Analysis of non-metal material on the carbon surface.

Block 6A

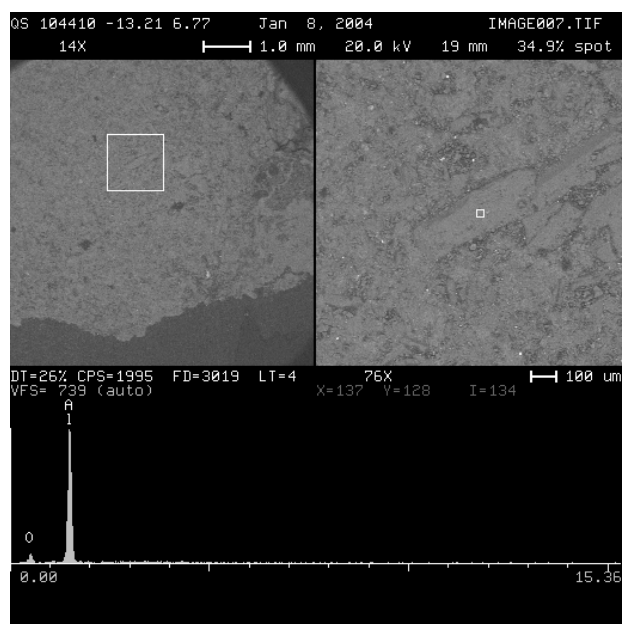

Block 8B

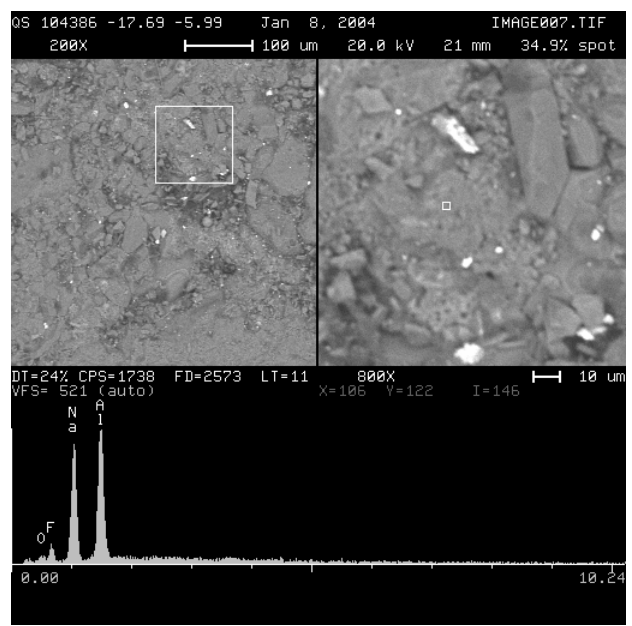

\section{Analysis for Cyanide}

Samples were collected from the bottom of cathode block $10 \mathrm{~A}$ and submitted to Century Aluminum of Kentucky to be analyzed for cyanide content. Steven Radcliffe and Jody Brown reported the following results: $0.21 \mathrm{ppm} \mathrm{CN}^{-}$for free $\mathrm{CN}^{-}$(72 hrs leaching process) and $0.09 \mathrm{ppm}$ for combined $\mathrm{CN}^{-}$(distillation process). At such levels, the material would not produce indications of toxic cyanide contents in TCLP testing.

The observed values were low. In laboratory tests at EMEC Consultants, the cyanide formation was suppressed to a level as low as $9 \mathrm{ppm}^{13}$. The (chemical) sodium activity in that formation test, with sodium at atmospheric pressure, was at least 10 times higher than is occurring in a cell bottom of an industrial cell, a suppression of cyanide formation to values of less than $1 \mathrm{ppm}$ was actually expected $^{21}$.

\section{Sampling and Analysis of Refractory Material From Below Cathode Blocks}

The refractory material under blocks $10 \mathrm{~A}$ and $10 \mathrm{~B}$ was examined for any deterioration, and the material seemed to be in good shape with a normal appearance. The layers under Block 10A were tested for boron content, which

21 EMEC Consultants, "Suppression of Cyanide Formation in Hall Process Potlining", Final Report, EPA SBIR Phase II Contract No. 68D10068 (1994). 
was discussed previously, and the analysis results are shown in Figure 20. Boron oxide was found to have leached into the top layer of refractory material in the pot; the glass layer under the block contained $3.65 \% \mathrm{~B}_{2} \mathrm{O}_{3}$, while the brick layer below contained $3.1 \% \mathrm{~B}_{2} \mathrm{O}_{3}$. The effects of this leaching are somewhat uncertain at this time, but it appears that this did not affect the thermal conductivity of the refractory material significantly and may not have contributed to the heat loss problems associated with this pot.

Results of thermal conductivity tests conducted by the Anter Laboratories, Pittsburgh, PA, are presented in Table 9. The data obtained from the upper brick layer can be compared with data obtained from an aged pot at Ravenswood. The thermal conductivity value for the boron oxide-containing sample is similar, even somewhat lower, than the sample from a regular pot. It appears that the heat conductance through the insulating brick layers was in essence not affected by the boron oxide.

This data is generally in line with data reported by Sorlie and Oye $\mathrm{e}^{20,22}$. These authors mention that a densification of the refractory material occurs due to interaction with fluorides and that values above $2600 \mathrm{Kg} / \mathrm{m}^{3}$ are not uncommon. Boron oxide may have a similar effect. The decrease of the thermal conductivity with increasing temperature is similar to the behavior observed with converted powder refractories, as shown in Figure 23.

22 M. Sorlie, H. Gran, and H. A. Oye, "Property Changes of Cathode Lining Materials During Cell Operation", Light Metals 1995, pp. 497-506 (1995). 
Table 9: Calculated thermal conductivity data.

\begin{tabular}{|c|c|c|c|c|c|}
\hline \multirow{3}{*}{ Sample } & $\begin{array}{c}\text { Temperature } \\
\left({ }^{\circ} \mathrm{C}\right)\end{array}$ & $\begin{array}{c}\text { Thermal } \\
\text { Diffusivity } \\
\left(\mathrm{cm}^{2} / \mathrm{s}\right)\end{array}$ & $\begin{array}{c}\text { Specific } \\
\text { Heat } \\
\text { Capacity } \\
(\mathrm{J} /(\mathrm{kg} \cdot \mathrm{K})\end{array}$ & $\begin{array}{c}\text { Density } \\
\left(\mathrm{kg} / \mathrm{m}^{3}\right)\end{array}$ & $\begin{array}{c}\text { Thermal } \\
\text { Conductivity } \\
(\mathrm{W} /(\mathrm{m} \cdot \mathrm{K})\end{array}$ \\
\hline \multirow{3}{*}{$\begin{array}{c}\text { EMEC } \\
\text { Autopsy }\end{array}$} & 400 & 0.0061 & 1603.1 & 2392.4 & 2.34 \\
\cline { 2 - 6 } & 600 & 0.0056 & 1603.1 & 2392.4 & 2.15 \\
\cline { 2 - 6 } & 750 & 0.0052 & 1603.1 & 2392.4 & 1.99 \\
\hline & 900 & 0.0049 & 1603.1 & 2392.1 & 1.88 \\
\hline \multirow{3}{*}{$\begin{array}{c}\text { Century } \\
\text { Normal }\end{array}$} & 400 & 0.0062 & 1690.7 & 2587.7 & 2.71 \\
\cline { 2 - 6 } & 750 & 0.0059 & 1690.7 & 2587.7 & 2.58 \\
\cline { 2 - 6 } & 900 & 0.0051 & 1690.7 & 2587.7 & 2.23 \\
\hline
\end{tabular}

Figure 23: Thermal conductivity data of powder refractory material.

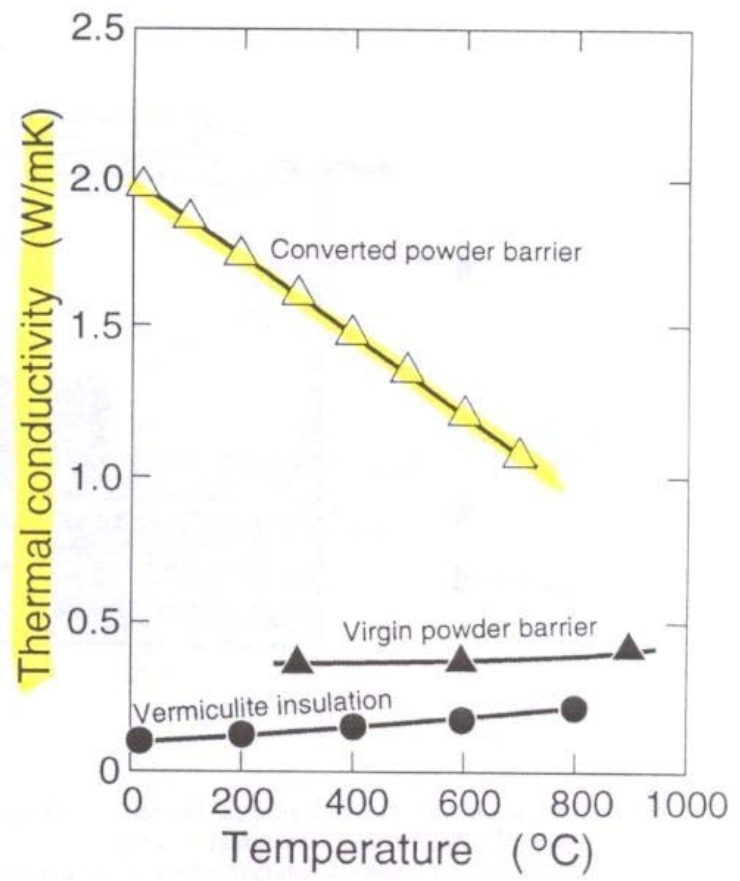

Thermal conductivity data of virgin and converted powder refractory barrier martial used in aluminum reduction cell cathodes. Data for virgin vermiculite insulation slabs are included for comparison. 


\section{Examination of Cast Iron at Collector Bar}

A sample of cast iron was collected from Block 10A, and the collector bars in general were examined for any abnormalities. The collector bars appeared to be normal with no deterioration or lack of connection with the carbon due to the presence of boron oxide. There was a material found on the collector bar, however. This was a clear, crystal like substance both at the cast iron - carbon interface and the cast iron - collector bar interface. It was thought that this may be boron oxide, but testing revealed that this material was actually aluminum oxide. The presence of this aluminum oxide is puzzling, but it was thought that this was not due to the presence of boron oxide in the block. The effects of this material, which is also found in other pots in the plant, are unknown at this time.

\section{Interpretation of Phase III -- Results and Conclusions}

The test at Century Aluminum did not produce the projected operational benefits. On the contrary, average voltage was about $0.12 \mathrm{~V}$ higher and the current efficiency was $2 \%$ lower. The pot showed generally high cathode voltage drops and had a tendency to form deposits with a resulting increase of noise; it ran like a "cold-bottom" pot.

There were some periods when pot data approached normal values, but such conditions were difficult to achieve and maintain. It appears that the heat loss through the bottom was excessive. Lowering the metal pad and increasing the cell voltage could counteract this effect. An increase in cell current, as another corrective action that would also increase production, was not possible with this pot.

The heat loss through the cell bottom, evidently, was excessive. Heat transfer through the carbon-metal interface may be enhanced by metal wetting the carbon. Additional insulation was incorporated in early cell tests by Boxall ${ }^{17}$ with titanium-diboride-containing coatings ${ }^{17}$.

It is proposed that boron oxide losses into the refractories could be counteracted by selecting appropriately effective barriers. Barriers are described in "Cathodes in Aluminum Electrolysis"20.

On the positive side, aluminum wetting the carbon was found in the pot, even 
under sludge or muck. SEM investigations indicated the presence of titanium diboride. Formation of $\mathrm{TiB}_{2}$, however, has to cease if titanium in the metal of the pool cannot reach the boron oxide at the carbon block surface. Remarkably, the observed wear rate was near zero, based on a measurement of block height; also, a tapping hole (eroded depression where tapping occurs, normally found after a year) was absent. Comalco reported ${ }^{23}$ wear rates of 8-12 mm/year for uncoated $30 \%$ graphitic blocks and $4 \mathrm{~mm} /$ year for their coated blocks; the coating was about $20 \mathrm{~mm}$ thick. It appears that the present approach by EMEC Consultants matches or surpasses Comalco's improved performance data.

The boron oxide in the cathode blocks did react with the titanium in the aluminum pool to form titanium diboride particles that caused the aluminum to wet the carbon surface. The reduced wear rate was a result of this wetting. While the energy savings could not be obtained in this project, the prospects of the savings, combined with the increased life of the cathode blocks, makes this process worth exploring in the future. The economic implications of this technology is explored and presented in the next section.

23 G. D. Brown, G. J. Hardie, R. W. Shaw, and M. P. Taylor, "TiB ${ }_{2}$ Coated Aluminum Reduction Cells: Status and Future Direction of Coated Cells in Comalco", Proceedings $6^{\text {th }}$ Australian Aluminum Smelting Workshop (1998). 


\section{CONTINUATION OF EFFORT AND COMMERCIALIZATION ASPECTS}

\section{CONTINUATION OF EFFORT}

The logical continuation of an effort to develop this technology to productive commercial implementation would be to conduct testing with cells employing graphitized blocks. One may start with the envisioned Phase-Il-type test with partial installation of impregnated blocks and partial autopsy; currents to individual blocks could be determined and may reveal differences between impregnated and non-impregnated blocks. Testing of fully equipped pots should follow, possibly including some modification of the cell design and of the pot operation.

A test involving ten pots would then reveal the degree of validity of the results of the previous tests. Minor variations in cell design and operation could be included. Some of the pots would be autopsied after one year; others continued to run to examine long time behavior. It is important to establish how long boron oxide remains effective.

\section{RE-USE OF PILOT EQUIPMENT}

The impregnation equipment used in the present project could be restarted. Operated in a 24-hour mode, one half-length block per day could be prepared, assuming that the previous overnight rest period with released pressure could be decreased to a few hours without significantly affecting the effectiveness of the impregnation. The production rate could essentially be doubled by introducing a preheat furnace and impregnating one full-length block at a time (height limitations of the vessel do not permit the preheating of a full-length block suspended above the melt).

The impregnation equipment is now stored by Precision, Inc. at their facility in Austintown, Ohio. To reactivate it, a new Inconel crucible needs to be acquired. Also a new furnace unit must be constructed and installed, as the old unit was damaged beyond repair in transit. The heat exchange unit needs to be reassembled and the entire equipment reinstalled. A test of the pressure vessel may have to be conducted. The following is a budget estimate for the cost of restarting the equipment. 
- Inconel crucible

- Furnace (inside vessel) from Thermcraft

42,000

- External Furnace (pre-heat of blocks) from Thermcraft

110,000

- Re-installation/set-up costs:

o Major equipment

25,000

o Upgrading power supply

7,000

o Misc.

7,000

- Miscellaneous expenses

15,000

- Total

227,600

The estimates are based on the costs incurred during the initial installation of the equipment at EMEC Consultants' pilot facility in Arnold, PA (Warren Haupin Pilot Facility). Thermcraft, however, provided the cost estimates for the internal furnace and the external pre-heat furnace, which is used to pre-heat up to 3 fullsized blocks before impregnation that is also suitable for the commercial equipment. These estimates do not include shipping costs and the impregnating entity's labor or consultant costs that will also be incurred during the initial set-up (possibly close to $\$ 100,000$ ).

\section{COMMERCIAL PRODUCTION EQUIPMENT}

The production rate for the impregnation can be increased by simultaneously treating several blocks. We envision the use of one or more pressure vessels, each accommodating three blocks at a time. Budget estimates are given below for the equipment as a capital item, and the operation costs to impregnate blocks for commercial cells is shown in Appendix 1 and 2 . No cost estimate for equipment to clean the excess boron oxide from the blocks is included; it is not determined how or if this task will be completed.

- Impregnation vessel

- Inconel crucible

- Internal Furnace

- External furnace (may already be purchased)

- Installation cost

- Miscellaneous

- Total
620,000

70,000

100,000

110,000

150,000

150,000

$1,200,000$

These estimates are based on the cost of the original pilot equipment costs that were up-scaled to the commercial equipment. Once again, however, Thermcraft 
provided the furnace estimates. These estimates are incorporated into the operational cost estimates that are presented in Appendix 1 and 2, which were used to determine the cost benefits the technology creates for the end-users of the technology.

\section{PROJECTION OF COST BENEFITS}

There are two main sources of cost benefits related to this technology. Potlining additives that induce the wetting of the cathode with $\mathrm{TiB}_{2}$ are expected to increase the life of the potlining by decreasing the wear rate of the cathode blocks. EMEC Consultants demonstrated this in the full pot test in Phase III. Increasing the life of the pot will create significant savings in relining, with respect to:

- Decreasing time out of production

- Purchasing pot materials less frequently

- Reducing pot line disposal costs

- Requiring less labor

The second source of cost benefits is the reduction in energy requirements.

EMEC Consultant analyzed cost and savings under several conditions and assumptions. Since the Phase III test indicated a decrease in wear rate, but the decrease in voltage was not demonstrated, cost/benefit analyses were completed with and without a voltage savings. A net present values (NPV) and overall savings/pound of aluminum produced were calculated under these conditions and, as shown in Table 10, there is a positive NPV and a significant savings of $\$ 0.006$ to $\$ 0.027$ per pound under each scenario. The wear rate reduction seems to be more significant than the potential power savings. The analysis was also conducted under two other assumptions; whether cathode blocks were impregnated by a facility with one or two pressure vessels, thus affecting the price of impregnation.

The main assumptions that were used in calculating the analysis include: an increase of pot life by $2 / 3$ the present life, a power savings of 0.2 volts, relining cost of $\$ 200,000$, a power cost of $\$ 0.025 / \mathrm{kWh}$, a discount rate of $10 \%$ for the aluminum smelter, and a tax rate of $32 \%$. The savings calculations are shown in Appendix 5 and Appendix 6. Any increase in production rate or current efficiency in the pot was not considered at this time, but it is possible that an even larger savings can be realized. The smelter must be able to deal with a titanium level of $0.025 \%$ in the metal, and it is assumed that the boron oxide will remain effective throughout the life of the pot. A more complete list of the assumptions and a more detailed analysis are presented in the Appendixes. 
Table10: Comparison of savings and NPVs based on present pot life of 1500 days.

Range of savings/lb of aluminum produced with power savings

\begin{tabular}{rrrrr} 
& \multicolumn{4}{c}{ Pot Current } \\
\cline { 3 - 5 } & & $\mathbf{1 0 0 0 0 0}$ & $\mathbf{1 5 0 0 0 0}$ & $\mathbf{2 0 0 0 0 0}$ \\
Expected Pot Life & $\mathbf{2 0 0 0}$ & $\$ 0.013$ & $\$ 0.015$ & $\$ 0.015$ \\
& $\mathbf{2 5 0 0}$ & $\$ 0.020$ & $\$ 0.022$ & $\$ 0.023$ \\
& $\mathbf{3 0 0 0}$ & $\$ 0.026$ & $\$ 0.027$ & $\$ 0.027$ \\
\hline
\end{tabular}

Range of savings/lb of aluminum produced w/o power savings

\begin{tabular}{rrrrr} 
& \multicolumn{3}{c}{ Pot Current } \\
\cline { 3 - 5 } & $\mathbf{1 0 0 0 0 0}$ & $\mathbf{1 5 0 0 0 0}$ & $\mathbf{2 0 0 0 0 0}$ \\
\cline { 3 - 5 } Expected Pot Life & $\mathbf{2 0 0 0}$ & $\$ 0.006$ & $\$ 0.008$ & $\$ 0.009$ \\
& $\mathbf{2 5 0 0}$ & $\$ 0.014$ & $\$ 0.015$ & $\$ 0.016$ \\
& $\mathbf{3 0 0 0}$ & $\$ 0.019$ & $\$ 0.020$ & $\$ 0.021$ \\
\hline
\end{tabular}

NPVs* With Power Savings @ \$ 0.025/kWh from two vessel facility

\begin{tabular}{|c|c|c|c|c|}
\hline & \multicolumn{3}{|c|}{ Pot Current } \\
\hline & & 100000 & 150000 & 200000 \\
\hline & 2000 & $\$ 22,244$ & $\$ 42,590$ & $\$ 62,936$ \\
\hline Expected Pot Life & 2500 & $\$ 36,907$ & $\$ 64,585$ & $\$ 92,262$ \\
\hline & 3000 & $\$ 46,683$ & $\$ 79,248$ & $\$ 111,813$ \\
\hline
\end{tabular}

NPVs* Without Power Savings from two vessel facility

\begin{tabular}{rrrrr} 
& \multicolumn{3}{c}{ Pot Current } \\
\cline { 3 - 4 } Expected Pot Life & $\mathbf{1 0 0 0 0 0}$ & $\mathbf{1 5 0 0 0 0}$ & $\mathbf{2 0 0 0 0 0}$ \\
\cline { 3 - 5 } & $\mathbf{2 0 0 0}$ & $\$ 7,480$ & $\$ 20,445$ & $\$ 33,409$ \\
& $\mathbf{2 5 0 0}$ & $\$ 22,144$ & $\$ 42,439$ & $\$ 62,735$ \\
$\mathbf{3 0 0 0}$ & $\$ 31,919$ & $\$ 57,103$ & $\$ 82,286$ \\
\hline
\end{tabular}

* NPV is the present value to the aluminum smelter of the savings that will be created with this technology based on the current assumptions. 


\section{PATENT SITUATION}

EMEC Consultants was awarded the following U.S. patents based on applications pre-dating the begining of this contract:

- U.S.Patent No. 5,538,604 (1996-07-23), "Suppression of Cyanide Formation in Electrolytic Cell Lining," R. Keller, C. N. Cochran and D. B. Stofesky.

- U.S. Patent No. 5,961,811 (1999-10-05), "Potlining to Enhance Cell Performance in Aluminum Production," R. Keller; also Australian Patent No. 748539 (2002-09-26).

Corresponding patent applications are pending in Canada and Norway.

Based on the presently reported work, the following patent was awarded:

- U.S. Patent No. 6,616,829 B2 (2003-09-09), "Carbonaceous Cathode with Enhanced Wettability for Aluminum Production," R. Keller, D. G. Gatty and B. J. Barca.

U.S. Patent No. 5,961,811 covers the basic principle of creating wettability of the cathode carbon surface by interaction of boron oxide placed in the cathode block and titanium added to the metal pool. U.S. Patent No. 6,616,829 B2, in essence, describes the impregnation of cathode blocks with a potlining additive such as boron-oxide-containing melt.

All patents were assigned to EMEC Consultants, a Small Business, who retains intellectual property rights according to pertinent Government Regulations. 


\section{THE VIRTUAL CONSORTIUM}

The partners participating in the present effort cost-shared to various extents. Century Aluminum Corporation made the largest contributions that now comprise those of their smelters in West Virginia and Kentucky (including those made by the former NSA). SGL Carbon Corporation and Northwest Aluminum Company are the other subcontractors, and EMEC Consultants is the prime contractor. It is envisioned that these firms form a business entity ("consortium") to license the technology. Each member would be assigned a share of interest based on the size of cost-share contributions.

This "consortium" will get an exclusive license to market the technology from EMEC Consultants who retains the patent rights to the inventions. Revenue from fees obtained from users of the technology will be shared by the "consortium" and EMEC Consultants.

The participating entities agreed that EMEC Consultants turned over the ownership of the pilot impregnation equipment to Precision Inc. Mr. Michael Pallotta, President of Precision Inc., is committed to store the equipment for up to 5 years (started spring of 2003) and operate it in a potential continuation of the developmental effort (or make the equipment available to another entity). 


\section{CONCLUSIONS AND RECOMMENDATIONS}

Phase I testing with laboratory-type samples confirmed the validity of the basic concept: titanium diboride formed through the interaction of boron oxide placed in the carbon cathode material with titanium added to the molten aluminum, and this promoted wetting of the carbon by the metal.

Titanium diboride did not form a compact coating on the carbon, but rather it was found as discrete small particles in the metal, in a zone adjacent to the carbon surface.

In exposure tests in industrial cells, a content of $0.025 \mathrm{wt} \%$ of titanium in the metal seemed to be sufficient to induce wetting of samples, but $0.008 \mathrm{wt} \% \mathrm{Ti}$ was not effective. Boron oxide additions to the carbonaceous material of $10 \mathrm{wt} \%$ and higher were effective.

The addition of boron oxide to green cathode material did not yield satisfactory properties of the baked material. A pressure impregnation of water-free boron oxide melt containing a small amount of borax was the preferred approach and was practiced to impregnate industrial cathode blocks. Impregnation values of 12 to $14 \mathrm{wt} \%$ boron oxide melt were typically achieved in the pilot plant treatment.

A Phase II test with six half-length amorphous cathode blocks placed in a pot, which then was operated with titanium additions to the metal pool for 6 months, did not yield any conclusive results. After pulling the solidified metal pad, no metal adhered to the carbon surface. About half of the initial boron oxide concentration was found in core-drilled samples. The pot did not display any special operational behavior; it is still operating well, more than one year after restart.

A Phase III test was run for 11 months in a cell fully equipped with impregnated half-length blocks. This pot showed an abnormal tendency to instability, with formation of sludge and hard muck. It could not be established conclusively if this was due to the presence of boron oxide in the block. Deposits precluding the direct contact of the metal pool with the carbon block surface suppress the formation of titanium diboride. Nevertheless some metal was found to adhere to the carbon surface, and indications of the presence of titanium diboride was revealed by SEM investigation.

The concentration of boron oxide remaining near the block surface after 11 
months of the Phase III test was about half to $2 / 3$ of the original content; it was actually about the same or higher than in the 6-month Phase II test. Lower values were found in lower parts of blocks. It was found that boron oxide penetrated into seams and as far as the first layer of refractories below the blocks. This did not seem to affect the insulating characteristics of this refractory layer adversely. The introduction of a barrier impermeable to boron oxide to stop this penetration should be considered.

Analysis of nonmetallic cathode deposits showed some accumulation of aluminum oxide, indicative of the presence of hard muck. Some deposits were discolored and the presence of aluminum boride was suspected, but no such aluminum boride could be identified by XRD analysis. It was speculated that aluminum boride could form under the sludge/muck, but the formation of aluminum boride is thermodynamically less favored than the formation of titanium diboride, provided a source of titanium is available. There seemed to be no aluminum boride formation in this case.

Measured cathode voltage drops were often high, but approached normal magnitude during relatively short periods of "clean" operation. Some increase was caused by an increase in resistivity due to the impregnation (measurements indicated that this should not be the case for graphitized material), on the other hand, there was, apparently, no contact resistance problem at the collector bars due to the presence of boron oxide. This was confirmed on recent measurements of cathode voltage drops on the Phase II blocks that were in line with values obtained on the other blocks, if anything being somewhat lower.

In this Phase III test, the projected operational improvements could not be demonstrated. On the contrary, the pot was very sensitive, displayed increased noise, and required higher voltage. It appeared to have an excessive heat loss through the bottom. On the other hand, a very low cathode wear rate was observed.

The test, however, did not negate the projections based on successes with $\mathrm{TiB}_{2^{-}}$ containing coatings reported in the literature. In areas where deposits ("muck" or sludge) covered the carbon surface, no titanium diboride could form, as the titanium added to the metal pool could not reach the boron oxide present in the blocks. An analysis of the metal layer recovered from an area between carbon and muck showed $<0.005 \mathrm{wt} \% \mathrm{Ti}$, which indicates that this metal was formed without being well connected to the metal pool. 
According to Taylor et $\mathrm{al}^{3}$, operational benefits are difficult to achieve with small cells. On the other hand, excellent, low wear rates were obtained. An extension of cathode life would be very attractive for larger cells with graphitized blocks. Nevertheless, the financial projections, discussed previously, that are based on the present results are very positive; the technology could yield a cost reduction of about 2 cents per pound of aluminum produced. It may be expected that the second planned Phase III test, with graphitized blocks, would have provided valuable additional information.

With the possibility of increasing the pot life of modern cells with graphitized cathode blocks in mind, continuation of the effort can be recommended. Aside from 6 half-length blocks stored in Goldendale, no impregnated material is presently available. Thus, the impregnation equipment must be reactivated, and more efficient equipment should be procured for additional, extensive testing. 


\section{APPENDIXES}

\section{Appendix 1}

Net Present Value (NPV) and Savings Analysis Assumptions

- Pot composed of 15 blocks sufficient to carry $200 \mathrm{kA}$.

- Amperage per pot is $200 \mathrm{kA}$.

- Present life expectancy of the pot is 1500 days.

- An increase in pot life of $2 / 3$ the present life.

- Production per day per pot is $3636 \mathrm{lbs}$.

- Each block contains $650 \mathrm{lbs}$ of boron oxide.

- Cost of relining is $\$ 200,000$.

- A power savings of 0.2 volts.

- Discount rate of $10 \%$ apr.

- Tax rate of $32 \%$.

- Cost of titanium addition is $\$ 1500$ per year.

- Cost of impregnation facility is $\$ 1,200,000$ per unit, depreciated over 10 years.

- Cost of impregnation depends on the size of the impregnation facility (see Appendixes 2 and 3 ).

- Spent potlining weighs 100 tons for a $200 \mathrm{kA}$ pot and must be treated and sent to a hazardous landfill at a cost of $\$ 420 /$ ton. It is possible that the boron oxide reduces the cyanide content that would eliminate the treatment of the material, thus reducing the expense for the potlining disposal to $\$ 120 /$ ton.

- Profit per lb of aluminum produced is $\$ 0.15$.

- Power cost to smelter is $\$ 0.025 / \mathrm{kWh}$. 


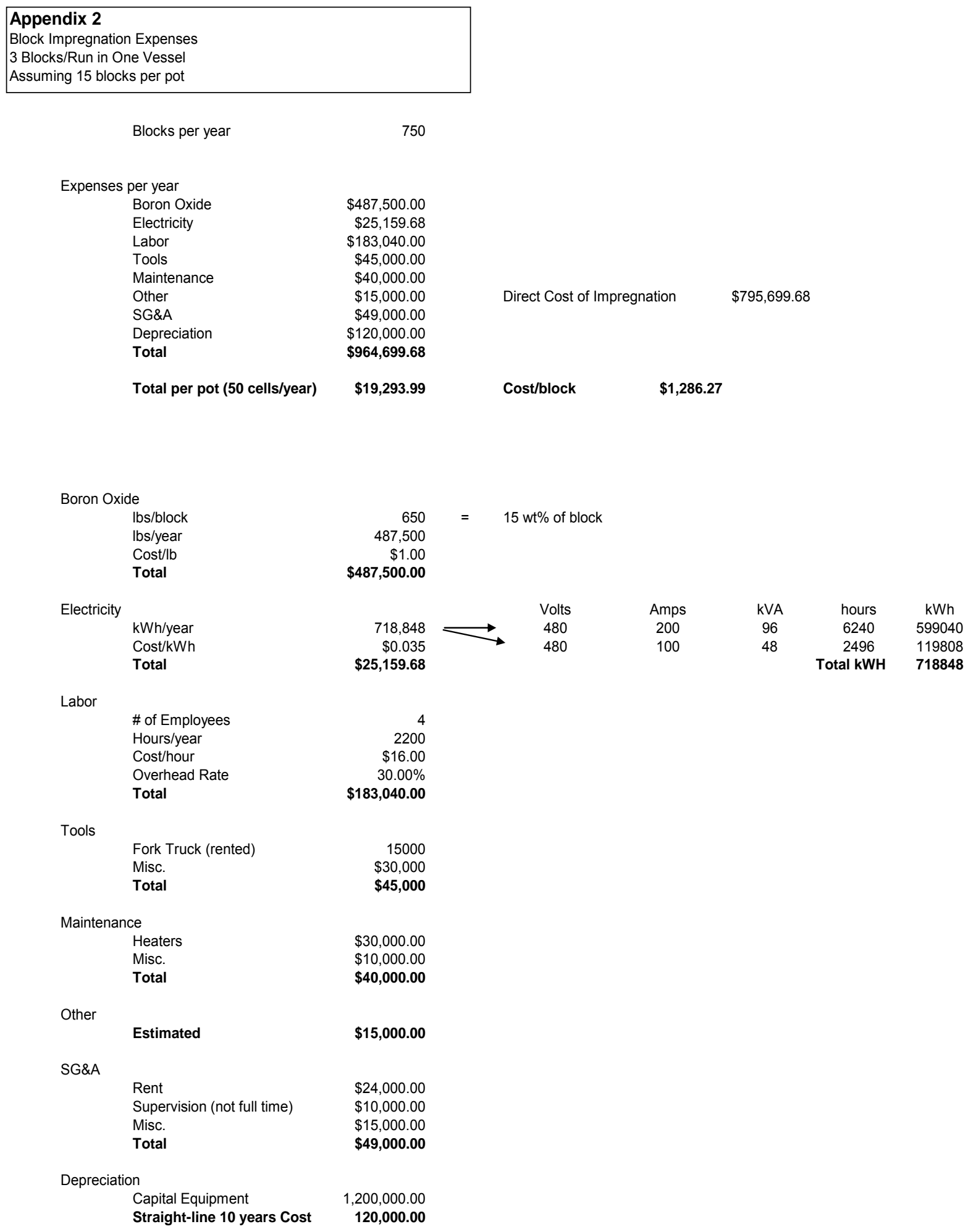




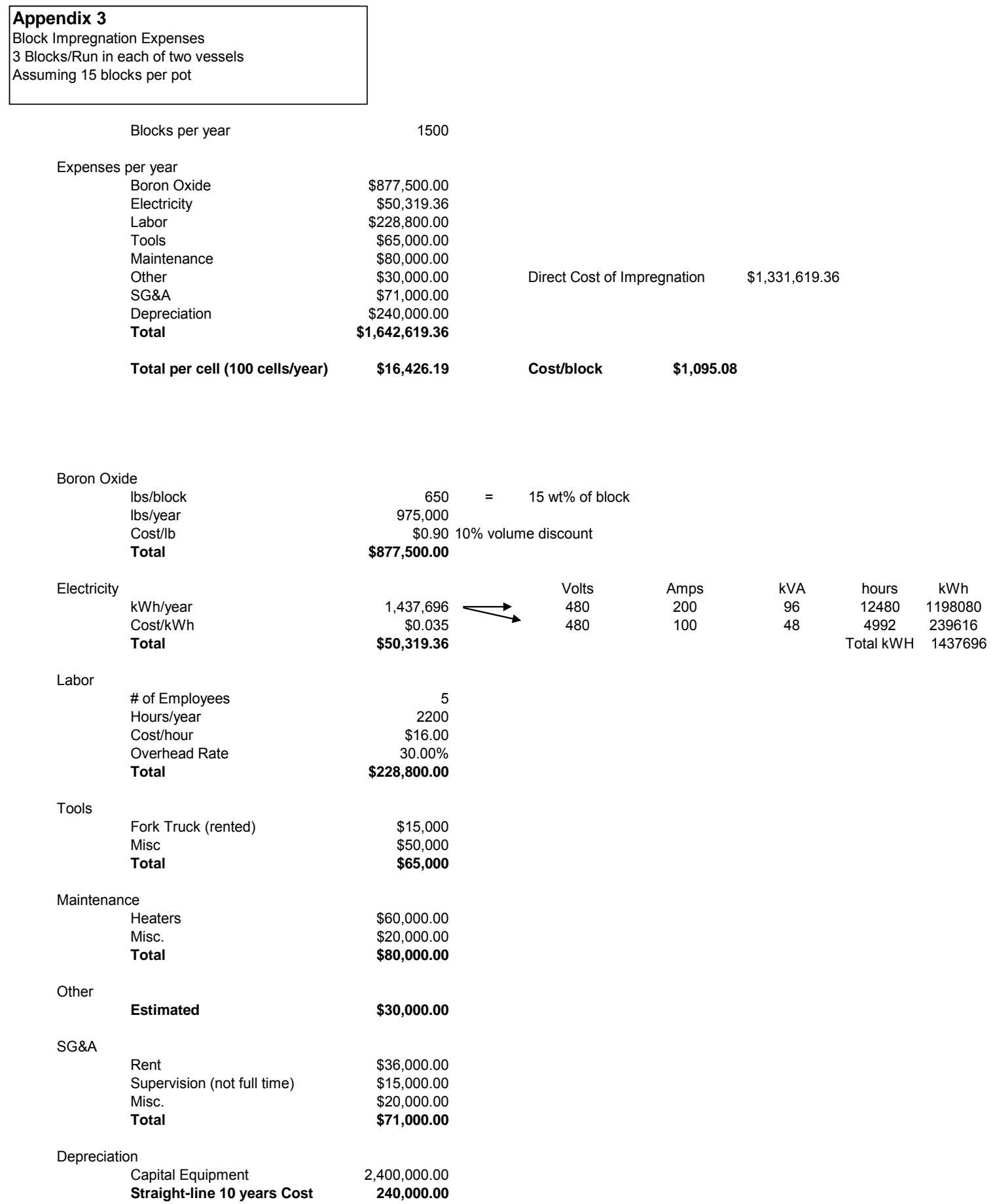




\section{Appendix 4}

Power savings calculation

Saving $0.2 \mathrm{~V}$

$\begin{array}{lc}\text { Pot Amperage } & 200 \mathrm{kA} \\ \text { Voltage Savings } & 0.2 \mathrm{~V} \\ \text { kVA savings } & 40 \\ \text { kWh/year savings } & 350,400 \\ \text { Power Cost/kWh } & \$ 0.025 \text { assumed } \\ \text { Power Savings } & \$ 8,760.000 \text { per year } \\ \text { Power Savings per day } & \mathbf{\$ 2 4 . 0 0 0}\end{array}$




\section{Appendix 5}

Savings/pot/day

with power savings

Cost of pot relining with regular blocks

Expected Life of pot w/o impregnation (days)

Expected life of pot with impregnation (days)

Cost of relining pot per day w/o impregnation

Cost of relining pot per day with impregnation

Savings/day

Power Saving/day

Savings per day for extended life of pot lining

Additional Savings

Production per day (lbs)

Days out of service to reline

Profit per pound of aluminum

Savings per day for extra production

Spent potline per pot (tons)

Cost of disposal per ton

Cost of disposal per day without increased life

Cost of disposal per day with increased life

Savings per day on disposal with extended life

Total Savings per day before impregnation cost

Cost of impregnation/pot

Cost of impregnation/day

Cost of impregnation/lb aluminum produced

Total Savings per daylafter impregnation

Total savings per pound produced
$\$ 200,000$

1500 Extension Ratio $\quad 0.666$

2499

$\$ 53$

$\$ 24$

$\$ 77$

$3,636 \longrightarrow 94 \%$ current efficiency

10

$\$ 0.15$

\$1.45 $\longrightarrow \quad$ Ibs produced per day @ \$.15/lb profit times day

out of service times extension ratio divided by 2499

100

$\$ 420$ Note: An additional savings in disposal may be realized, see Appendix 11.

$\$ 28.00$

$\$ 16.81$

$\$ 11.19$

$\$ 89.95$

from two vessels

$\$ 19,711.432$

$\$ 7.89$

$\$ 0.0022$

$\$ 82.06$

$\$ 0.023$

from one vesse

$\$ 23,152.792$

$\$ 9.26$

$\$ 0.0025$

$\$ 80.68$

$\$ 0.022$ 


\section{Appendix 6}

Savings/pot/day

Without power savings
Cost of cell relining with regular blocks

Expected Life of pot w/o impregnation (days)

Expected life of pot with impregnation (days)

Cost of relining cell per day w/o impregnation

Cost of relining pot per day with impregnation

Savings/day

Power Saving/day

Savings per day for extended life of pot lining

Additional Savings

Production per day (lbs)

Days out of service to reline

Profit per pound of aluminum

Savings per day for extra production

Spent potline per pot (tons)

Cost of disposal per ton

Cost of disposal per day without increased life

Cost of disposal per day with increased life

Savings per day on disposal with extended life

Total Savings per day before impregnation cost

Cost of impregnation/pot

Cost of impregnation/day

Cost of impregnation/lb aluminum produced

Total Savings per daylafter impregnation cost Total savings per pound produced
$\$ 200,000$

1500 Extension Ratio $\quad 0.666$

2499

$\$ 133$

$\$ 80$

$\$ 53$

$\$ 53$

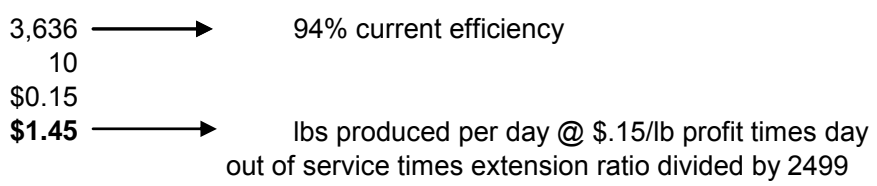

100

$\$ 420$

$\$ 28.00$

$\$ 16.81$

$\$ 11.19$

$\$ 65.95$

from two vessels

$\$ 19,711.432$

$\$ 7.89$
$\$ 0.0022$

$\$ 0.0022$

$\$ 58.06$

$\$ 0.016$ out of service times extension ratio divided by 2499
from one vesse
$\$ 23,152.79$
$\$ 9.26$
$\$ 0.003$
$\$ 56.68$
$\$ 0.016$ 


\section{Appendix 7}

Cost/Benefit Analysis

Impregnation Facility

Impregnation Facility with one vessel

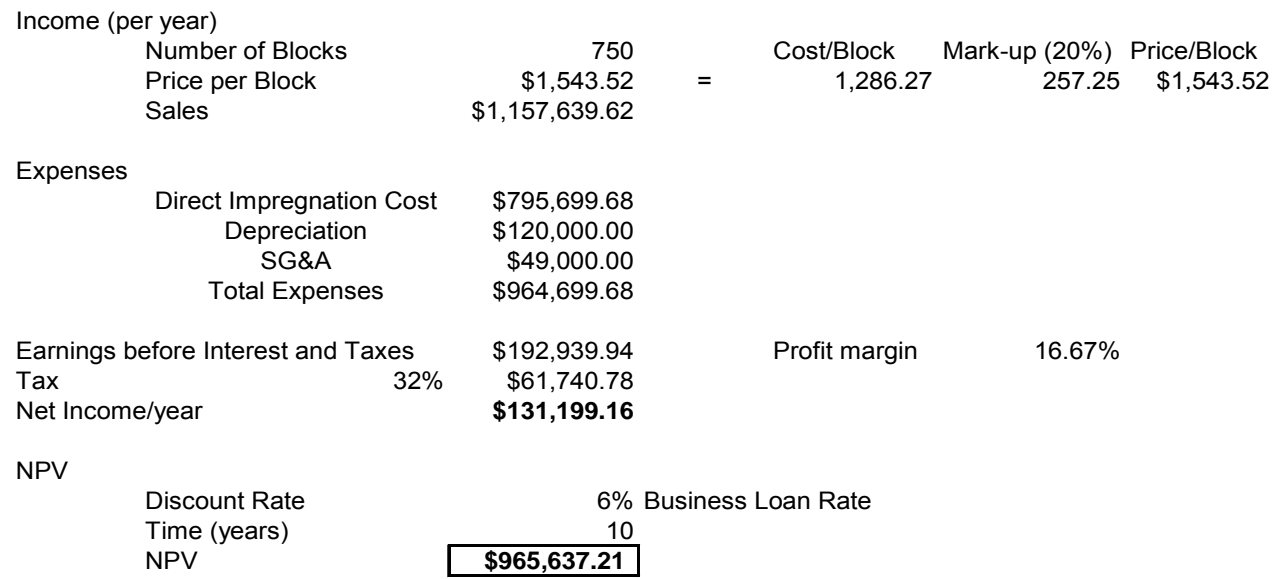

Impregnation Facility with two vessels

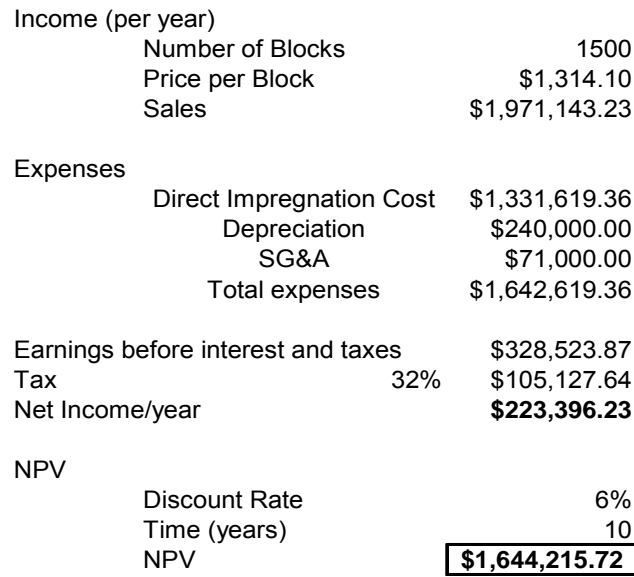


Appendix 8

Cost/Benefit Analysis - Per Pot

With power savings

Aluminum Plant from one vessel facility

Income/day

Savings/pot/day

Discounted Savings

Expenses/Life

Imp. Cost

Present Value of Ti Addition

Additional Supervision

Total

NPVIPot Before Taxes

NPVIPot After Taxes

$$
\begin{array}{rrc}
\text { Discount rate } & \text { Discount rate/day } & \text { Time (days) } \\
10 \% & 0.000273973 & 2499
\end{array}
$$

$\$ 89.95$

$\$ 162,740.51$

$$
\begin{array}{r}
\$ 23,152.79 \\
\$ 7,418.00 \\
\$ 0.00
\end{array}
$$

Blocks per pot

Ti Cost/day

15 Cost/block $\$ 1,543.52$

$\$ 30,570.79$

\section{$\$ 132,169.72$}

$32 \% \$ 89,875.41$
Aluminum Plant from two vessels facility

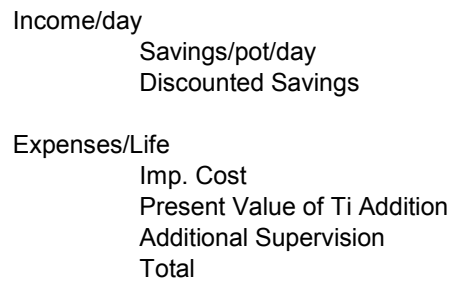

NPV/Pot Before Taxes NPV/Pot After Taxes $\begin{array}{rrc}\text { Discount rate } & \text { Discount rate/day } & \text { Time (days) } \\ 10 \% & 0.000273973 & 2499\end{array}$

$\$ 89.95$

$\$ 162,740.51$

$$
\begin{array}{r}
\$ 19,711.43 \\
\$ 7,418.00 \\
\$ 0.00
\end{array}
$$

Blocks per pot

Ti Cost/day

15 Cost/block $\$ 1,314.10$

$\$ 27,129.43$

$\$ 4.10$

$\$ 135,611.08$

$32 \% \quad \$ 92,215.54$ 
Appendix 9

Cost/Benefit Analysis - Per Pot

With out power savings

Aluminum Plant from one vessel facility

Income/day

Savings/pot/day

Discounted Savings

Expenses/Life

Imp. Cost

Present Value of Ti Addition

Additional Supervision

Total

NPVIPot Before Taxes

NPVIPot After Taxes

$$
\begin{array}{rrc}
\text { Discount rate } & \text { Discount rate/day } & \text { Time (days) } \\
10 \% & 0.000273973 & 2499
\end{array}
$$

$\$ 65.95$

$\$ 119,318.08$

$$
\begin{array}{r}
\$ 23,152.79 \\
\$ 7,418.00 \\
\$ 0.00
\end{array}
$$

Blocks per pot

Ti Cost/day

15 Cost/block $\$ 1,543.52$

$\$ 30,570.79$

\begin{tabular}{|l|r|}
\hline $32 \%$ & $\$ 88,747.29$ \\
\hline$\$ 60,348.16$ \\
\hline
\end{tabular}

$\$ 4.10$
Aluminum Plant from two vessels facility

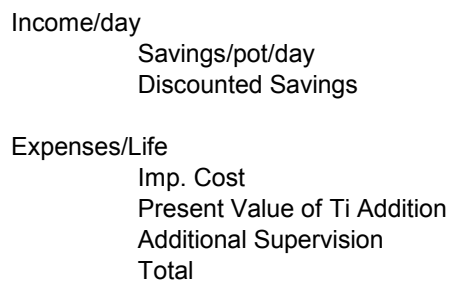

NPVIPot Before Taxes NPVIPot After Taxes
Discount rate Discount rate/day Time (days)

$\begin{array}{lll}10 \% & 0.000273973 \quad 2499\end{array}$

$\$ 65.95$

$\$ 119,318.08$

$$
\begin{array}{r}
\$ 19,711.43 \\
\$ 7,418.00 \\
\$ 0.00
\end{array}
$$$$
\text { Blocks per pot }
$$$$
\text { Ti Cost/day }
$$

15 Cost/block $\$ 1,314.10$

$\$ 27,129.43$

$\$ 4.10$

\begin{tabular}{|r|r|}
\hline $32 \%$ & $\$ 92,188.65$ \\
\hline$\$ 62,688.28$ \\
\hline
\end{tabular}




\section{Appendix 10}

Summary of the Net Present Values (NPVs)

Based on present pot life of 1500 days

Range of savings/pot/day with power savings

Pot Current

\begin{tabular}{c|rrr|}
\multicolumn{4}{c}{ Pot Current } \\
\cline { 3 - 4 } $\mathbf{2 0 0 0}$ & $\mathbf{1 0 0 0 0 0}$ & $\mathbf{1 5 0 0 0 0}$ & $\mathbf{2 0 0 0 0 0}$ \\
$\mathbf{2 5 0 0}$ & $\$ 3.22$ & $\$ 39.76$ & $\$ 56.29$ \\
$\mathbf{3 0 0 0}$ & $\$ 4.11$ & $\$ 59.61$ & $\$ 82.10$ \\
\cline { 2 - 4 } & & $\$ 72.84$ & $\$ 99.31$ \\
\hline
\end{tabular}

Range of savings/lb of aluminum produced with power savings

Pot Current

\begin{tabular}{l|rrr|}
\multicolumn{5}{c}{ Pot Current } \\
\multicolumn{10}{c}{} & $\mathbf{1 0 0 0 0 0}$ & $\mathbf{1 5 0 0 0 0}$ & $\mathbf{2 0 0 0 0 0}$ \\
$\mathbf{2 0 0 0}$ & $\$ 0.013$ & $\$ 0.015$ & $\$ 0.015$ \\
$\mathbf{2 5 0 0}$ & $\$ 0.020$ & $\$ 0.022$ & $\$ 0.023$ \\
$\mathbf{3 0 0 0}$ & $\$ 0.026$ & $\$ 0.027$ & $\$ 0.027$ \\
\hline
\end{tabular}

Aluminum Smelter NPV per pot for life of pot

Blocks from one pressure vessel

\begin{tabular}{lr|rrr|} 
& \multicolumn{5}{c}{ With Power Savings @ \$ 0.025/kWH } \\
& & \multicolumn{4}{c}{ Pot Current } \\
\cline { 3 - 6 } Expected Pot Life & $\mathbf{1 0 0 0 0 0}$ & $\mathbf{1 5 0 0 0 0}$ & $\mathbf{2 0 0 0 0 0}$ \\
& $\mathbf{2 0 0 0}$ & $\$ 19,904$ & $\$ 40,250$ & $\$ 60,596$ \\
& $\mathbf{2 5 0 0}$ & $\$ 34,567$ & $\$ 62,245$ & $\$ 89,922$ \\
& $\mathbf{3 0 0 0}$ & $\$ 44,343$ & $\$ 76,908$ & $\$ 109,473$ \\
\hline
\end{tabular}

Blocks from two pressure vessels

With Power Savings @ \$ 0.025/kWH

$$
\text { Pot Current }
$$

\begin{tabular}{|c|c|c|c|}
\hline & 1000 & 150000 & 200000 \\
\hline & $\$ 22,2$ & $\$ 42,590$ & $\$ 62$, \\
\hline & $\$ 36,907$ & $\$ 64,585$ & $\$ 92,262$ \\
\hline & $\$ 46,683$ & $\$ 79,248$ & $\$ 111,8$ \\
\hline
\end{tabular}

Expected Pot Life
Range of savings/pot/day without power savings

Expected Pot Life

\begin{tabular}{l|rrr|}
\multicolumn{4}{c}{ Pot Current } \\
\multicolumn{10}{c}{$\mathbf{1 0 0 0 0 0}$} & $\mathbf{1 5 0 0 0 0}$ & $\mathbf{2 0 0 0 0 0}$ \\
\cline { 2 - 4 } $\mathbf{2 0 0 0}$ & $\$ 11.22$ & $\$ 21.76$ & $\$ 32.29$ \\
$\mathbf{2 5 0 0}$ & $\$ 25.11$ & $\$ 41.61$ & $\$ 58.10$ \\
$\mathbf{3 0 0 0}$ & $\$ 34.37$ & $\$ 54.84$ & $\$ 75.31$ \\
\cline { 2 - 4 } & & &
\end{tabular}

Range of savings/lb of aluminum produced w/o power savings

Expected Pot Life

\begin{tabular}{l|rrr|}
\multicolumn{3}{c}{ Pot Current } \\
$\mathbf{1 0 0 0 0 0}$ & $\mathbf{1 5 0 0 0 0}$ & $\mathbf{2 0 0 0 0 0}$ \\
& $\$ 0.006$ & $\$ 0.008$ & $\$ 0.009$ \\
$\mathbf{2 5 0 0}$ & $\$ 0.014$ & $\$ 0.015$ & $\$ 0.016$ \\
$\mathbf{3 0 0 0}$ & $\$ 0.019$ & $\$ 0.020$ & $\$ 0.021$ \\
\hline
\end{tabular}

Expected Pot Life

Without Power Savings
Pot Current
\begin{tabular}{r|rrr}
$\mathbf{1 0 0 0 0 0}$ & $\mathbf{1 5 0 0 0 0}$ & $\mathbf{2 0 0 0 0 0}$ \\
$\mathbf{2 0 0 0}$ & $\$ 5,140$ & $\$ 18,105$ & $\$ 31,069$ \\
$\mathbf{2 5 0 0}$ & $\$ 19,803$ & $\$ 40,099$ & $\$ 60,395$ \\
$\mathbf{3 0 0 0}$ & $\$ 29,579$ & $\$ 54,762$ & $\$ 79,946$ \\
\hline
\end{tabular}

Without Power Savings

Pot Current

\begin{tabular}{|c|c|c|c|}
\hline & \\
\hline & 100000 & 150000 & 200000 \\
\hline & $\$ 7,4$ & $\$ 20,4$ & \\
\hline 500 & $\$ 22,144$ & $\$ 42,439$ & $\$ 62,73$ \\
\hline & & & \\
\hline
\end{tabular}

Expected Pot Life 


Appendix 11
Savings/pot/day if the potlining can be disposed of without treatment for cyanide
with power savings

Cost of pot relining with regular blocks

Expected Life of pot w/o impregnation (days)

Expected life of pot with impregnation (days)

Cost of relining pot per day w/o impregnation

Cost of relining pot per day with impregnation

Savings/day

Power Saving/day

Savings per day for extended life of pot lining

\section{Additional Savings}

Production per day (Ibs)

Days out of service to reline

Profit per pound of aluminum

Savings per day for extra production

Spent potline per pot (tons)

Cost of disposal per ton

Cost of disposal per ton per day (1500 days)

Cost of disposal per ton w/o hazardous treatment

Cost of disposal per ton w/o hazardous treatment per day (extended life days)

Savings per day on disposal with extended life

Total Savings per day before impregnation cost

Cost of impregnation/pot

Cost of impregnation/day

Cost of impregnation/lb aluminum produced

Total Savings per daylafter impregnation

Total savings per pound produced

\section{$\$ 200,000$}

1500 Extension I $\quad 0.666$

2499

$\$ 133$

$\$ 80$

$\$ 53$

$\$ 24$

$\$ 77$

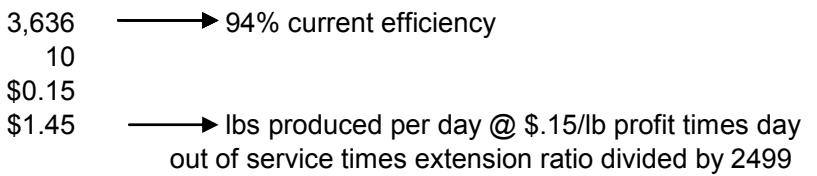

100

$\$ 420$

$\$ 28.00$

$\$ 120$

$\$ 23.20$

$\$ 101.95$

\begin{tabular}{rr|}
$\begin{array}{r}\text { from two vessels } \\
\$ 19,711.432\end{array}$ & from one vessel \\
$\$ 7.89$ & $\$ 23,152.792$ \\
$\$ 0.0022$ & $\$ 9.26$ \\
& $\$ 0.0025$ \\
\hline$\$ 94.07$ & $\$ 92.69$ \\
\hline $\mathbf{\$ 0 . 0 2 6}$ & $\$ \mathbf{0 . 0 2 5}$ \\
\hline
\end{tabular}

